\title{
Time/Motion Observations and Dose Analysis of Reactor Loading, Transportation, and Dry Unloading of an Overweight Truck Spent Fuel Shipment
}
C. J. Hostick
J. C. Lavender
B. H. Wakeman

April 1992

Prepared for the U.S. Department of Energy under Contract DE-AC06-76RLO/1830

Pacific Northwest Laboratory

Operated for the U.S. Department of Energy

by Battelle Memorial Institute

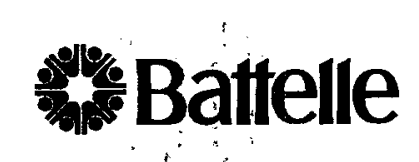




\title{
DISCLAIMER
}

This report was prepared as an account of work sponsored by an agency of the United States Government. Neither the United States Government nor any agency thereof, nor Battelle Memorial Institute, nor any of their employees, makes any warranty, expressed or implied, or assumes any legal liability or responsibility for the accuracy, completeness, or usefulness of any information, apparatus, product, or process disclosed, or represents that its use would not infringe privately owned rights. Reference herein to any specific commercial product, process, or service by trade name, trademark, manufacturer, or otherwise does not necessarily constitute or imply its endorsement, recommendation, or favoring by the United States Government or any agency thereof, or Battelle Memorial Institute. The views and opinions of authors expressed herein do not necessarily state or reflect those of the United States Government or any agency thereof.

\author{
PACIFIC NORTHWEST LABORATORY \\ operated by \\ BATTELLE MEMORIAL INSTITUTE \\ for the \\ UNITED STATES DEPARTMENT OF ENERGY \\ under Contract DE-ACO6-76RLO 1830
}

Printed in the United States of America

Available to DOE and DOE contractors from the

Office of Scientific and Technical Information, P.O. Box 62, Oak Ridge, TN 37831;

prices available from (615) 576-8401. FTS 626-8401.

Available to the public from the National Technical Information Service, U.S. Department of Commerce, 5285 Port Royal Rd., Springfield, VA 22161. 


\section{DISCLAIMER}

This report was prepared as an account of work sponsored by an agency of the United States Government. Neither the United States Government nor any agency Thereof, nor any of their employees, makes any warranty, express or implied, or assumes any legal liability or responsibility for the accuracy, completeness, or usefulness of any information, apparatus, product, or process disclosed, or represents that its use would not infringe privately owned rights. Reference herein to any specific commercial product, process, or service by trade name, trademark, manufacturer, or otherwise does not necessarily constitute or imply its endorsement, recommendation, or favoring by the United States Government or any agency thereof. The views and opinions of authors expressed herein do not necessarily state or reflect those of the United States Government or any agency thereof. 


\section{DISCLAIMER}

Portions of this document may be illegible in electronic image products. Images are produced from the best available original document. 
TIME/MOTION OBSERVATIONS AND DOSE ANALYSIS

OF REACTOR LOADING, TRANSPORTATION, AND

DRY UNLOADING OF AN OVERWEIGHT TRUCK

SPENT FUEL SHIPMENT

C. J. Hostick

J. C. Lavender (a)

B. H. Wakeman (b)

April 1992

Prepared for

the U.S. Department of Energy

under Contract DE-AC06-76RLO 1830

Pacific Northwest Laboratory

Richland, Washington 99352

(a) Westinghouse Hanford Company, Richland, Washington

(b) Virginia Electric and Power Company, Richmond, Virginia. 


\section{SUMMARY}

This document presents observed activity durations and radiation dose analyses for an overweight truck shipment of pressurized water reactor (PWR) spent fuel from the Surry Power Station in Virginia to the Idaho National Engineering Laboratory. The shipment consisted of a TN-8L shipping cask carrying three 9-year-old PWR spent fuel assemblies. Handling times and dose analyses for at-reactor activities were completed by Virginia Electric and Power Company (Virginia Power) personnel. Observations of in-transit and unloading activities were made by Pacific Northwest Laboratory (PNL) personnel, who followed the shipment for approximately 2800 miles and observed cask unloading activities. In-transit dose estimates were calculated using dose rate maps provided by Virginia Power for a fully loaded TN-8L shipping cask. The dose analysis for the cask unloading operations is based on the observations of PNL personnel.

A summary of observed handling times and dose analysis is shown in Table S.1. It should be noted that over $72 \%$ of the dose received during cask loading operations at the reactor is due to background radiation. In-transit doses were calculated for the drivers using the dose rate map for the TN-8L shipping cask and represent 35.9 person-mrem or $66 \%$ of the in-transit dose.

TABLE S.1. Activity Durations and Associated Radiation Doses for Transport of Spent Reactor Fuel Using a TN-8L Overweight Truck Cask

\begin{tabular}{lccc}
\multicolumn{1}{c}{ Activity } & Time (hr) & Dose (person-mrem) \\
Reactor Loading & 14.1 & 136 \\
In-transit & 62.0 & 54 \\
Dry Unloading & 8.2 & 131
\end{tabular}




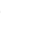




\section{CONTENTS}

SUMMARY

1.0 INTRODUCTION . . . . . . . . . . . . . . . . 1.1

1.1 TN-8L CASK DESCRIPTION . . . . . . . . . . . . . 1.2

1.2 STATE AND FEDERAL REgULATIONS . . . . . . . . . . 1.4

1.2.1 Federal Regulations . . . . . . . . . . . 1.6

1.2.2 State Regulations ................. 1.7

1.2.3 Impacts of State Regulations . . . . . . . . . . 1.11

1.3 REPORT ORGANIZATION ................... . . 1.11

2.0 CASK LOADING AT REACTOR . . . . . . . . . . . . . . . 2.1

2.1 REACTOR CASK HANDLING . . . . . . . . . . . . . . 2.1

2.1.1 Surry Nuclear Power Plant Cask-Handling

Facilities ................ 2.1

2.1.2 Cask-Handling Operations . . . . . . . . 2.3

2.1.3 Staffing Requirements for Reactor

Cask-Handling .............. 2.8

2.1.4 Reactor Shipping Cask-Handling Times . . . . . 2.8

2.2 DOSE EVALUATION FOR REACTOR CASK-HANDLING . . . . . . 2.12

3.0 IN-TRANSIT ASSESSMENT . . . . . . . . . . . . . . . . 3.1

3.1 IN-TRANSIT DATA . . . . . . . . . . . . . . 3.1

3.2 STOPS DATA . . . . . . . . . . . . . . 3.3

3.2.1 Weigh Stations ............... 3.3

3.2.2 Rest Area ................... 3.4

3.2.3 Truck Stops .................. 3.4

3.2.4 Badge House . . . . . . . . . . . . . . 3.6

3.3 IN-TRANSIT DOSE EVALUATION . . . . . . . . . . . 3.6 
3.3.1 In-Transit Dose Estimates . . . . . . 3.6

3.3.2 Stops Dose Estimates ................. 3.11

3.3.3 Summary of the Dose Estimates . . . . . . . 3.12

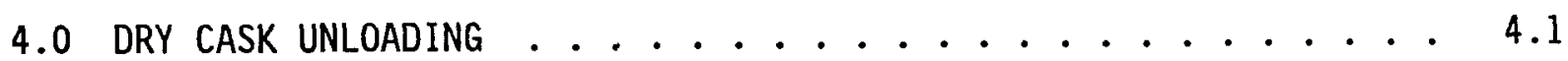

4.1 DRY CASK HANDLING .................... 4.1

4.1.1 TAN-607 Warm and Hot Shops .......... 4.1

4.1 .2 Cask-Handling Operations ........... 4.6

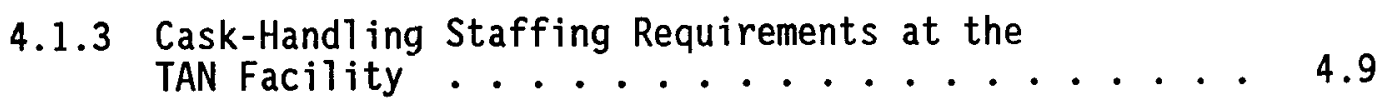

4.1.4 TAN Facility Cask-Handling Times ........ 4.9

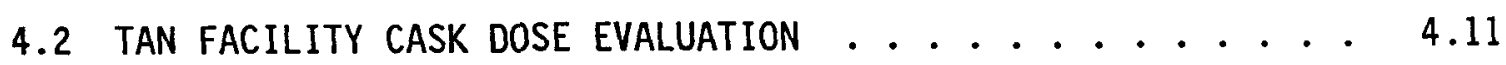

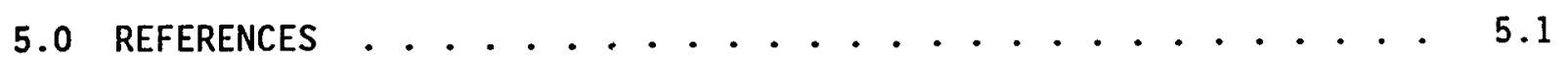

APPENDIX A - TN-8L CASK HANDLING--REACTOR LOADING . . . . . . A.1

APPENDIX B - IN-TRANSIT DATA COLLECTION . ......... B. 1

APPENDIX C - CALCULATION OF IN-TRANSIT AND STOPS EXPOSURES TO

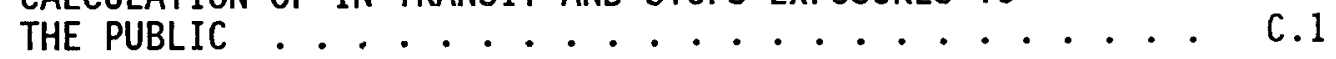

APPENDIX D - TN-8L CASK HANDLING--HOT SHOP UNLOADING $\ldots \ldots \ldots . . \ldots$ D.I 


\section{FIGURES}

1.1 Radial Cross-Section of the TN-8L Cask . . . . . . . . 1.2

1.2 Isometric View of the TN-8L Cask . . . . . . . . . . 1.3

1.3 TN-8L Cask Transport Arrangement . . . . . . . . . 1.3

1.4 Loaded TN-8L Cask Shipment . . . . . . . . . . . 1.4

1.5 Route Used to Transport Spent Fuel from Virginia to INEL. . . . 1.5

2.1 Cask-Handling Facilities at the Surry Nuclear Power Plant . . . 2.2

2.2 Organization Matrix for $\mathrm{TN}-8 \mathrm{~L}$ Shipments . . . . . . . 2.9

2.3 Cask Dose Rate Map . . . . . . . . . . . . . 2.13

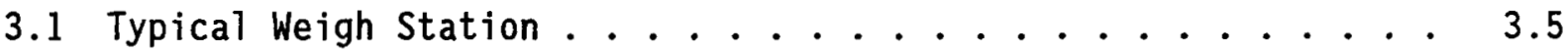

3.2 A Typical Refueling Stop .............. 3.5

3.3 Typical Dimensions of 4-Lane Interstate . . . . . . . 3.7

4.1 Top View of the TAN-601 Warm and Hot Shops Cask-Handling
Facility . . . . . . . . . . . . . . . . .

4.2 Truck Backing into Warm Shop Area . . . . . . . . . . 4.2

4.3 Hot Shop Shipping Cask Removal From the Transport Vehicle . . . 4.2

4.4 MC-10 Storage Cask . . . . . . . . . . . . 4.3

4.5 The Removable Portion of the Work Platform . . . . . . 4.4

4.6 Hot Shop Dual Cask Workstand . . . . . . . . . . . . 4.5 


\section{TABLES}

S.1 Activity Durations and Associated Radiation Doses for Transport of Spent Reactor Fuel Using a TN-8L Overweight Truck Cask . . . . iii

2.1 Staffing Requirements . . . . . . . . . . . . . . . 2.8

2.2 Reactor Shipping Cask Handling Times . . . . . . . . . . . 2.10

2.3 Total Travel and Turnaround Times . . . . . . . . . . . 2.11

2.4 Cask Surface Dose Rates . . . . . . . . . . . . . . . . 2.14

2.5 Background Dose Rates . . . . . . . . . . . . . . . . 2.14

2.6 Personnel Dose by Activity . . . . . . . . . . . . . 2.15

2.7 Personnel Dose by Location . . . . . . . . . . . . . . 2.16

3.1 Summary of In-Transit Data: Vehicle Counts . . . . . . . 3.2

3.2 Summary of In-Transit Data: Population Zones . . . . . . . . 3.3

3.3 Summary of Stops Data . . . . . . . . . . . . . . . 3.4

3.4 Distances Used to Calculate the In-Transit Dose to
the Public . . . . . . . . . . . . . . . . . . . . 3.8

3.5 Summary of Vehicle Counts Used to Calculate Public Doses . . . 3.8

3.6 In-Transit Dose Estimates for Shipment No. 20 . . . . . . . 3.10

3.7 Calculated Doses for In-Transit Stops . . . . . . . . . . . 3.11

3.8 Summary of Dose Estimates . . . . . . . . . . . . . . . 3.13

4.1 TAN Facility Shipping-Cask Handling Times Activity . . . . . . . 4.10

4.2 TAN Facility Personnel Dose due to Unloading Activities . . . . 4.12 


\section{$1.0 \quad$ INTRODUCTION}

To provide information for a study of repository transportation system alternatives, personnel from Pacific Northwest Laboratory (PNL) collected cask handling and transport times and calculated personnel exposure resulting from the transportation by truck of spent nuclear fuel from the Surry Power Station in Virginia [operated by Virginia Electric and Power Company (Virginia Power)] to the Department of Energy's (DOE) Test Area North (TAN) facility at the Idaho National Engineering Laboratory (INEL). Information was collected on the Surry Power Station spent fuel shipment because it is representative of part of the expected repository transportation system. The shipment consisted of wet-cask loading at the reactor, cross-country haul, and dry-cask unloading into a hot shop. The analyses of at-reactor cask loading was prepared by Virginia Power personnel. In-transit data were obtained by PNL personnel who followed the approximately 2800 mile shipment. Shipping cask unloading at INEL was also observed by PNL personnel. This document provides additional information in support of the study of federal waste management system transportation alternatives being completed by PNL for the DOE (DOE 1987).

Data collected by Virginia Power were used to calculate occupational dose estimates for spent fuel cask handling, wet loading, and shipping for at-reactor operations. The $\mathrm{TN}-8 \mathrm{~L}$ dose rate map, also provided by Virginia Power, and the in-transit data collected by PNL personnel were used to calculate public dose estimates for the cross-country haul. The data collected by PNL personnel at INEL during cask receiving, handling, and dry unloading operations was used to calculate occupational dose estimates for dry unloading.

The spent fuel was transported by an overweight truck consisting of a Transnuclear (TN) Inc. shipping cask containing three pressurized water reactor (PWR) spent fuel assemblies with an average cooling time of 9 years. This document presents data collected during April of 1986 on shipment number 20 of the 23 shipments completed by the Surry Power Station. Shipments 8 through 23 followed the route shown in Figure 1.1. Shipments 1 through 7 followed a different route and are not addressed in this document. A 


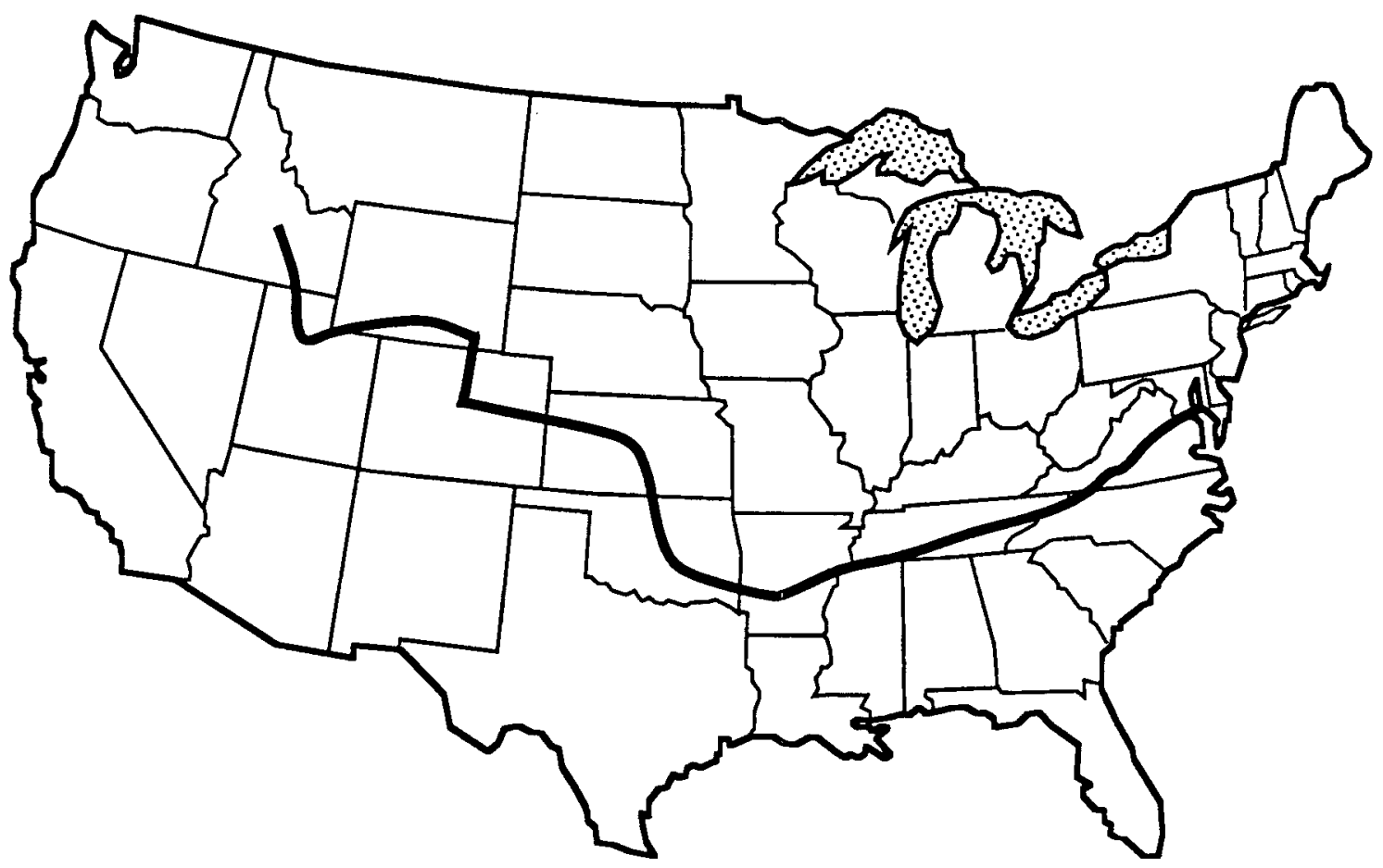

FIGURE 1.1. Route Used to Transport Spent Fuel from Virginia to INEL

description of the TN-8L shipping cask is presented in Section 1.1, and the applicable regulations for spent fuel shipments are presented in Section 1.2.

\subsection{TN-8L CASK DESCRIPTION}

The 40-ton TN-8L shipping casks are designed for overweight truck shipments of about 1.4 metric tons of uranium (MTU) of spent fuel. Gross vehicle weight is approximately 105,000 pounds. The TN-8L cask, designed for PWR spent fuel assembiies, is constructed of steel with lead for gamma shielding and a solid hydrogenous material for neutron shielding. A radial cross section of the cask is shown in Figure 1.2. The three spent fuel assembly compartments are surrounded by lead gamma shielding. Between the lead shielding and the outer steel shell is a layer of cement. Located externally to the outer steel shell are a solid hydrogenous material neutron shield and radial copper fins. The stainless steel lid contains lead and resin shielding, and the removable impact limiters are constructed of carbon steel and balsa wood. An isometric view of the TN-8L cask is shown in Figure 1.3. 


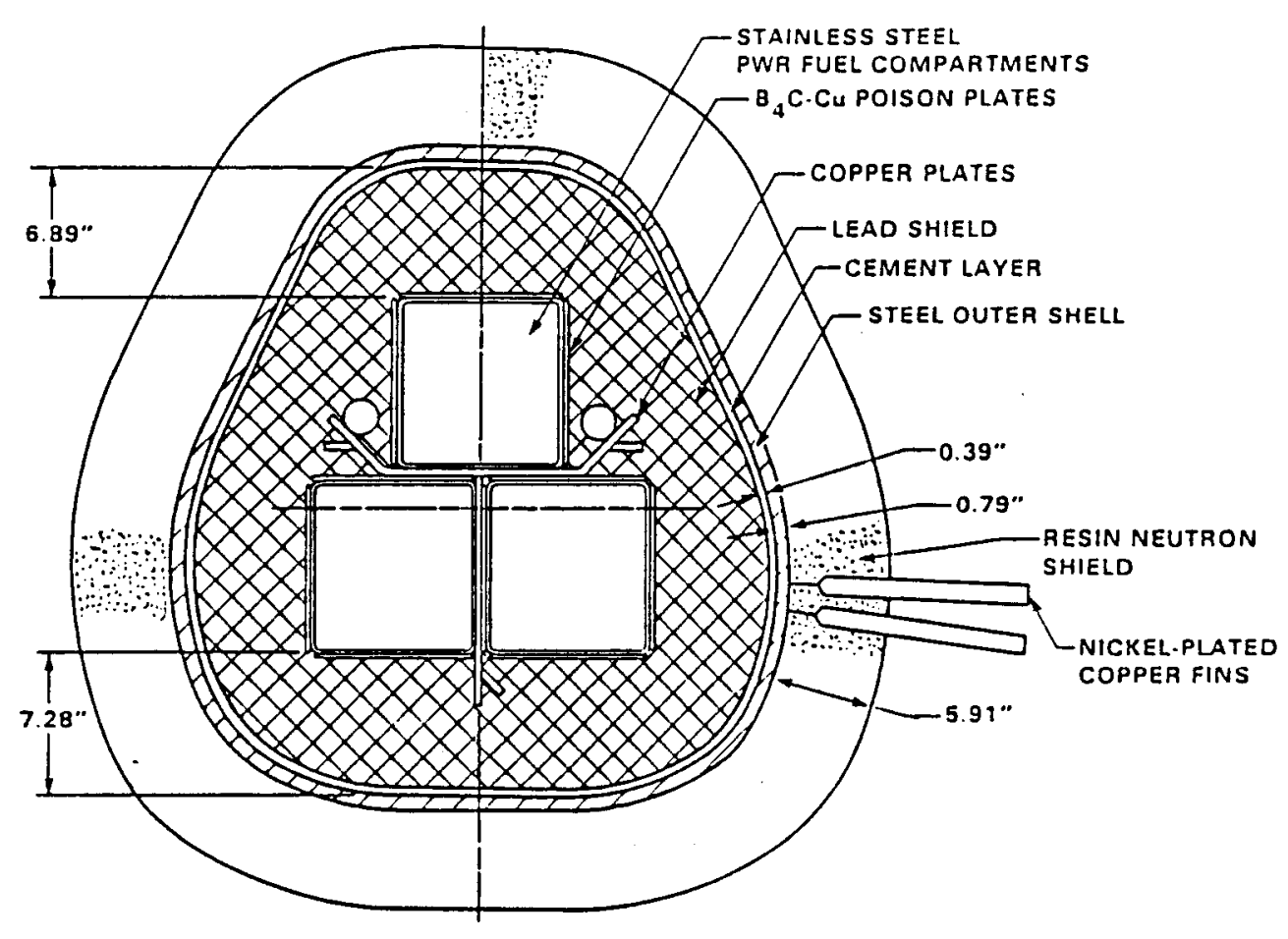

FIGURE 1.2. Radial Cross-Section of the TN-8L Cask

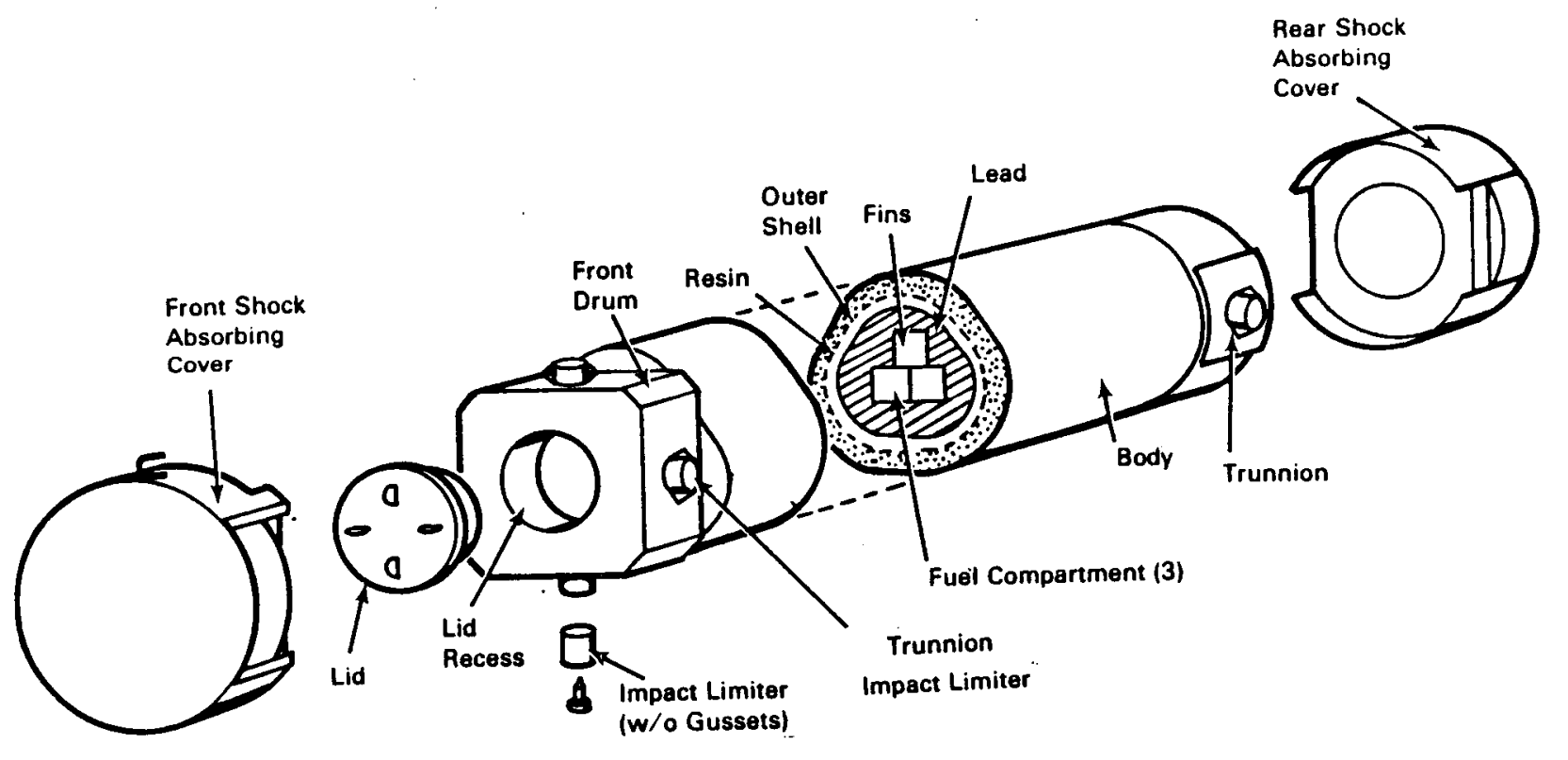

FIGURE 1.3. Isometric View of the TN-8L Cask 
The 1 id is secured by 16 1-1/4-inch-diameter bolts and two 0-rings located within recessed grooves on the top flange. The impact 1 imiters are attached to the cask by eight 1-1/4-inch bolts. Rear cask tiedowns to the trailer consist of two clamps (one clamp on each side), which are secured by two bolts each. The front tiedowns consist of two quick release clamps extending from the trailer bed over the front trunnions, as shown by Figure 1.4. A11 trunnions are protected by a smal1 impact 1 imiter secured by one bolt while in transit. The personnel barrier consists of a tarpaul in covering a collapsible frame. The loaded trailer and closed personnel barrier is shown in Figure 1.5 .

\subsection{STATE AND FEDERAL REGULATIONS}

This section summarizes the state and federal regulations regarding overweight or oversize shipments of spent fuel. Section 1.2.1, which summarizes the federal regulations, was taken from 49 CFR $171-177$ and applies to

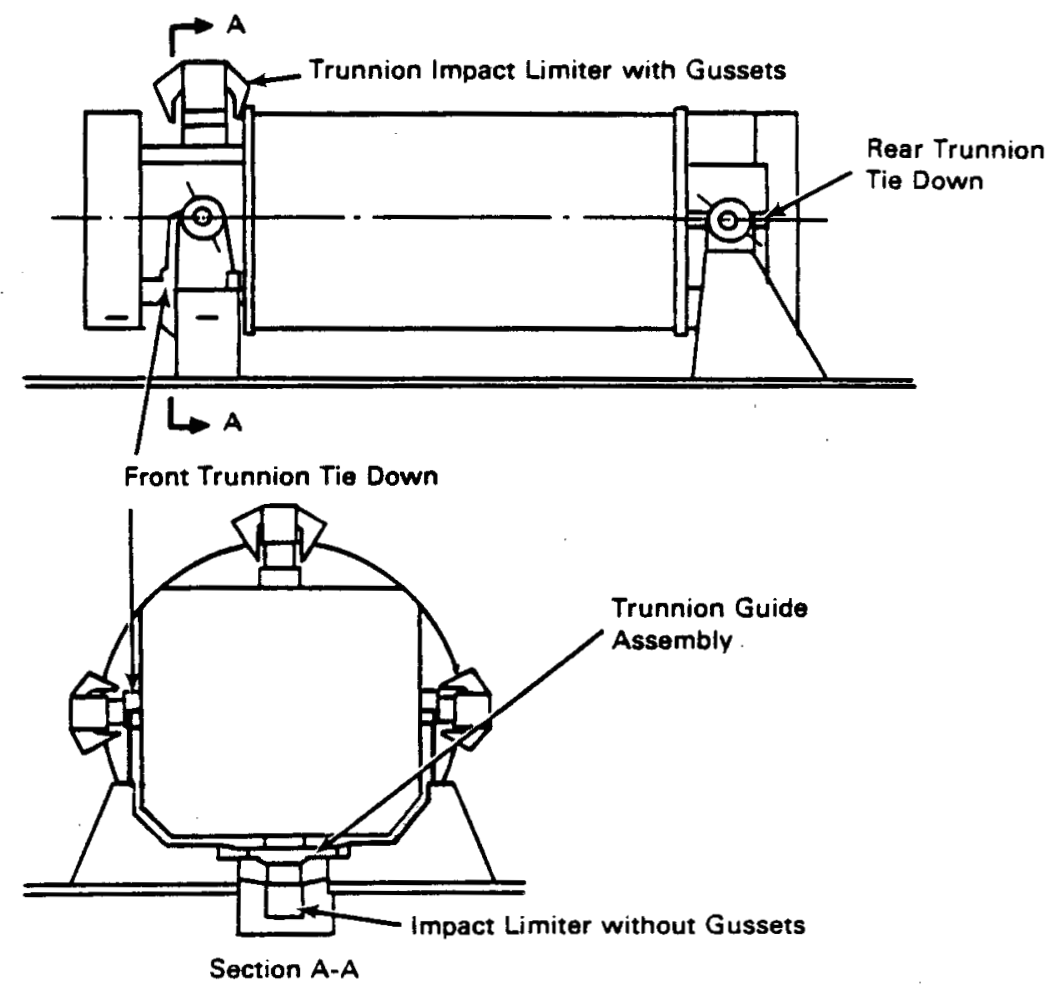

FIGURE 1.4. TN-8L Cask Transport Arrangement 


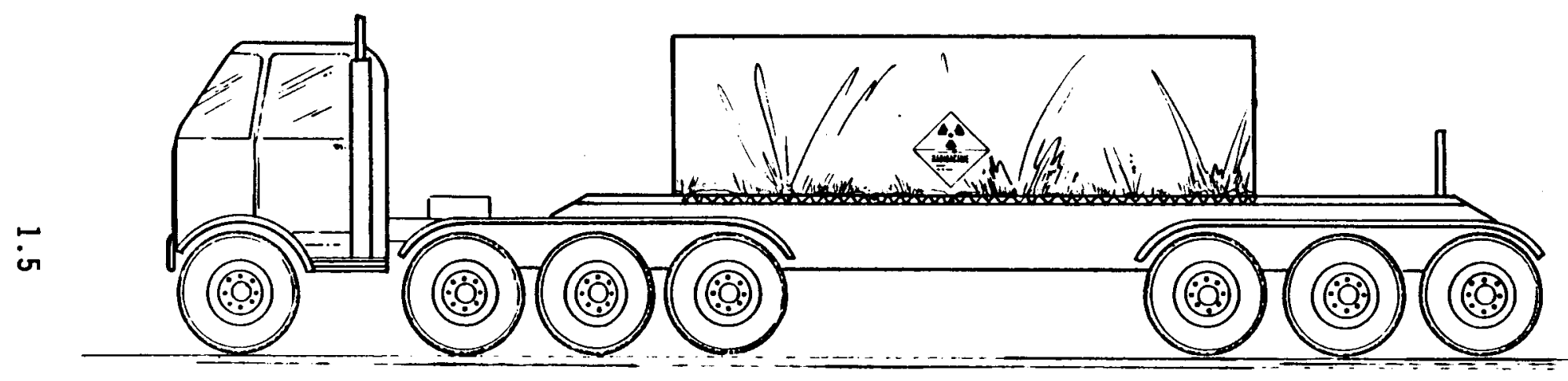

FIGURE 1.5. 'Loaded. TN-8L Cask Shipment 
all states encountered enroute to INEL. The state regulations, summarized in Section 1.2.2, usually apply in addition to the federal regulations. The state regulations described apply only to the states passed through enroute.

\subsubsection{Federal Regulations}

Shipments of spent fuel are regulated by one or more of four federal agencies: the U.S. Department of Transportation (DOT), the DOE, the U.S. Nuclear Regulatory Commission (NRC), and the Interstate Commerce Commission (ICC). The ICC is principally responsible for the economics of transporting nuclear materials. The other agencies are responsible for the safe transport of hazardous materials or spent nuclear fuel.

The regulations have been designed to ensure the safe transport of hazardous or radioactive materials. The regulations include provisions for route selection, the performance and design of shipping packages, vehicle safety, and the physical protection of the shipment (e.g., protection from sabotage). These regulations are intended to reduce the potential for routine public and occupational exposures and to protect the public and the environment from accidental releases.

The specific regulations that apply to shipments of spent fuel are contained in the U.S. Code of Federal Regulations (CFR). Regulations governing the shipment of spent fuel by truck are contained in the following CFR sections:

- 49 CFR 107. Rule-Making Procedures for the Materials Transportation Bureau

- 49 CFR 171. General Information, Regulations, and Definitions

- 49 CFR 172. Hazardous Materials Table and Hazardous Materials Communications Regulations

- 49 CFR 173. Shippers-General Requirements for Shipments and Packages

- 49 CFR 177. Carriage by Public Highway

- 49 CFR 178. Shipping Container Specifications

- 10 CFR 71. Package and Radioactive Material for Transport and Transportation of Radioactive Material under Certain Circumstances 
- 10 CFR 73. Physical Protection of Plants and Materials.

Two of the above sections are relevant to this study and will be discussed briefly in the following paragraphs: 49 CFR 177, Carriage by Public Highway and 49 CFR 178, Shipping Container Specifications. (For further information on these sections, refer to the pertinent sections in 49 CFR.)

The DOT routing regulations (49 CFR 177.825) have been designed to reduce the impacts of transporting nuclear materials and to identify the responsibilities and roles of state and local governments in the route selection process. Routes are normally selected that will reduce shipment times and routine exposures to the public. Shippers of hazardous or radioactive materials are generally required to use interstates and preapproved routes to bypass highly populated areas.

Shipping containers or casks used during offsite shipments of commercial spent fuel must be designed to survive extreme test conditions (10 CFR 71.73) and must be licensed by the NRC. These tests include immersion, free drop, fire, and puncture. These packages are also designed to limit the amount of radiation emitted from the package. These amounts or limits are specified in 49 CFR 173.441 and are as follows:

- $1000 \mathrm{mR} / \mathrm{hr}$ at $1 \mathrm{~m}$ from the exterior of the package (in a closed transport vehicle only)

- $200 \mathrm{mR} / \mathrm{hr}$ at any point on the external surface of the car or vehicle (in a closed transport vehicle only)

- $10 \mathrm{mR} / \mathrm{hr}$ at any point $2 \mathrm{~m}$ from the vertical planes projected from the outer surfaces of the car or vehicle (in a closed transport vehicle only) or $2 \mathrm{~m}$ from the outer edges of the transport vehicle (as in the observed shipment)

- $2 \mathrm{mR} / \mathrm{hr}$ in any normally occupied position in the car or vehicle.

\subsubsection{State Regulations}

This subsection discusses the special regulations that were in effect at the time of shipment number 20 from the Surry Power Station. The regulations include overweight or oversize travel restrictions, and restrictions or regulations applying specifically to radioactive materials. 
The regulations that are identified for each state are in addition to the requirements identified in 49 CFR. All states, except Idaho and OKlahoma, have passed legislation regarding the transportation of spent fuel through their respective states (Knox et al. 1986). Over a period of time, overweight shipments can damage bridges, overpasses, or road surfaces; therefore, some states have regulated overweight shipments generally through the use of increased tariffs. Travel restrictions during nights, weekends, or holidays are also used to regulate overweight and oversize shipments.

The following subsections discuss each of the state's restrictions regarding the transportation of hazardous materials and/or nonstandard (overweight or oversize) shipments. Not all of the restrictions discussed were applicable to this particular shipment (i.e., routing, etc.). Each state will be discussed in the same order as they were encountered during the shipment. Figure 1.1 shows the route followed from the Surry Power Station to INEL.

\subsubsection{Virginia (1986 Requlations)}

Virginia requires the Coordinator of the Office of Emergency Services (COES) be notified 5 days prior to shipment of spent fuel. This notification must include the proposed route and method of transportation, the time of transportation, the material to be transported, and additional materials requested by the COES (Knox et a1. 1986). The 5-day period will allow the COES sufficient time to approve the proposed route, to notify all cities along the proposed route, or disapprove a route and notify the shipper.

Nonstandard shipments, such as spent fuel shipment number 20 , require that traffic be stopped on two-lane bridges, allowing the shipment to cross in the center of the bridge. Virginia also restricts nonstandard shipments during holidays, the half days adjacent to holidays, and nights.

Although not required by state regulation, Virginia Power provided two escort vehicles for the shipment. The purpose of these vehicles was to maintain a constant surveillance of the shipment to the state border. 


\subsubsection{North Carolina (1986 Regulations)}

North Carolina requires the shipper to notify, in advance, the State Highway Patrol prior to transporting spent fuel. The State Radiation Protection Commission has the power to amend or repeal any of the rules governing the shipment of spent fuel.

Nonstandard shipments are restricted during holidays and the adjacent Mondays, Saturdays and Sundays, and at night.

\subsubsection{Tennessee (1986 Regulations)}

Tennessee has legislation requiring that radiation monitoring equipment be available at motor vehicle inspection and weigh stations in Knox, Coffee, Hayword, and Robinson Counties. This legislation also requires or provides training programs to familiarize state officials with the use of the equipment. Tennessee enacted legislation naming the Public Service Commission (PSC) as the-licenser and regulator of all motor vehicles involved in the transport of spent fuel. The PSC issues interstate permits allowing the carrier to transport spent fuel. The PSC, in agreement with the Tennessee Department of Transportation, inspects the carrier's vehicle and performs a radiation survey at the port of entry.

Overweight shipments, such as shipment number 20 , are also assessed an additional tax of $\$ 0.05$ for each pound in excess of the legal shipping weight. Tennessee also requires that nonstandard shipments, regardless of the material transported, be made during daylight hours only; however, 6 hours of negotiations between the carrier and the state resulted in the waiver of this restriction for the shipments from Surry Power Station to INEL, so shipment number 20 passed through Tennessee at night.

\subsubsection{Arkansas (1986 Requlations)}

Arkansas has no legislation specifically regulating the transportation of spent fuel (Knox et a1. 1986). However, Arkansas has legislation regarding spills, accidents, and the identification of hazardous materials. It can be assumed that these regulations apply to shipments of spent fuel. 
Arkansas also requires that nonstandard shipments be made during daylight hours only. However, negotiations with the state resulted in a waiver of this restriction for the shipments from Surry Power Station to INEL.

\subsubsection{Oklahoma (1986 Regulations)}

As of April 1986, Oklahoma had no legislation regarding the transport of spent nuclear fuel. There are no restrictions regarding overweight shipments in effect at that time.

\subsubsection{Kansas (1986 Regulations)}

The State of Kansas requests a notification in writing 10 days prior to arrival of the first shipment and the completion of the last shipment through the state. In this notification, the route, time frame, enter/exit points, and emergency contact(s) are identified.

Kansas restricts overweight shipments during holidays, on the evening of the last day of a holiday, on Sundays, and at night.

\subsubsection{Colorado (1986 Regulations)}

Colorado has identified the State Board of Health as the agency to adopt and identify regulations regarding the shipment of any radioactive materials. The Manager of Safety has been designated to regulate shipments in the County of Denver, including the City of Denver. The manager identifies and approves the routes to be used. The Director of Excise and Licenses approves the shipper's request for an application to ship hazardous materials and also collects an applicant's fee.

Nonstandard shipments are restricted during holidays, Saturday evenings, Sundays, and at night.

\subsubsection{Wroming (1986 Regulations)}

No legislation has been identified for Wyoming (Knox et al. 1986).' The governor, by Governor Order, has requested that shippers of radioactive materials contact the State Patrol prior to entry and wait at the port of entry for a State Patrol escort through the state. It is then the responsibility 
of the State Patrol to provide an escort vehicle through each district of the state. This vehicle is to maintain constant surveillance of the transport vehicle.

Nonstandard shipments can be made during daylight hours only.

\subsubsection{Utah (1986 Regulations)}

Utah has passed legislation adopting the DOT regulations regarding shipments of hazardous materials and has no specified nonstandard shipment restrictions.

\subsubsection{Idaho (1986 Requlations)}

Idaho has not passed any legislation regulating the transport of spent nuclear fuel within its boundaries (Knox et al. 1986). The travel of nonstandard shipments is restricted during holidays, Saturday evenings, Sundays, and at night.

\subsubsection{Impacts of State Regulations}

Negotiations between the carrier and the states encountered enroute from the Surry Power Station to INEL were held prior to the shipping campaign. These negotiations resulted in waivers for most of the restrictions that are applicable to nonstandard and hazardous materials shipments. Three restrictions were not waived; however, these restriction did not severely impact the shipment. The three restrictions enforced by the states were:

- Virginia - State police stopped traffic when the shipment crossed over a small bridge.

- Tennessee - Tennessee DOT inspected the vehicle and surveyed the shipment at the port of entry.

- Wyoming - Required a state police escort from the port of entry to the Utah border.

\subsection{REPORT ORGANIZATION}

This report is divided into four chapters and four appendices. In Chapter 2.0, the analyses of at-reactor cask loading is presented. Chapter 3.0 contains the in-transit data, and shipping cask unloading at INEL is summarized in Chapter 4.0. 
Appendix A lists the detailed cask-handling steps for at-reactor cask loading and the data collected for each step. Appendix B presents the data collection forms and the in-transit data collected during the shipment. Appendix $C$ presents the calculations of exposures to the public, both in-transit and during stops, and Appendix $D$ provides dose information from hot-shop unloading of the TN-8L cask. 


\subsection{CASK LOADING AT REACTOR}

Handling times based on multiple cask loadings and personnel exposure calculations using measured and predicted dose rates were completed for the loading of the TN-8L shipping cask at the Surry Power Station by Virginia Power personnel. Loading operations, handling times, and personnel requirements are presented in Section 2.1. Personnel exposure resulting from shipping-cask loading operations are presented in Section 2.2.

\subsection{REACTOR CASK HANDLING}

As part of the NRC certification process for the TN-8L shipping cask, a generic handling procedure for both cask loading and unloading was developed. The loading portion of this generic procedure was used to develop Surry operations Procedure OP-4.3. This procedure was then tested in a training exercise and simulated loading, and further refinements were made. This final draft of OP-4.3 was then reviewed and approved by Transnuclear, Inc.; Surry Power Station Quality Assurance Personnel; and the Station Nuclear Safety and Operating Committee.

Cask-handling facilities at Surry Power Station are described in Section 2.1.1. Cask-handling operations are summarized in Section 2.1.2, and staff requirements are outlined in Section 2.1.3. Cask-handling times are discussed in Section 2.1.4.

\subsubsection{Surry Nuclear Power Plant Cask-Handling Facilities}

A top view of the cask-handling facilities at Surry Power Station is provided in Figure 2.1. Cask-handling facilities consist of the Crane Enclosure Area, the Decontamination Building, and the Fuel Building. After the shipping cask and transport vehicle arrive at the main vehicle gate, receipt inspections are performed. The cask is then transferred to the Crane Enclosure Area and removed from the transport vehicle in a horizontal position, rotated 90 degrees, and $\mathrm{placed}$ into a lifting cradle. The horizontal 1 ift to a lifting cradle is required because the tracks for the overhead crane are perpendicular to the orientation of the parked shipping cask trailer. The tracks are perpendicular because of space limitations on where the truck can 


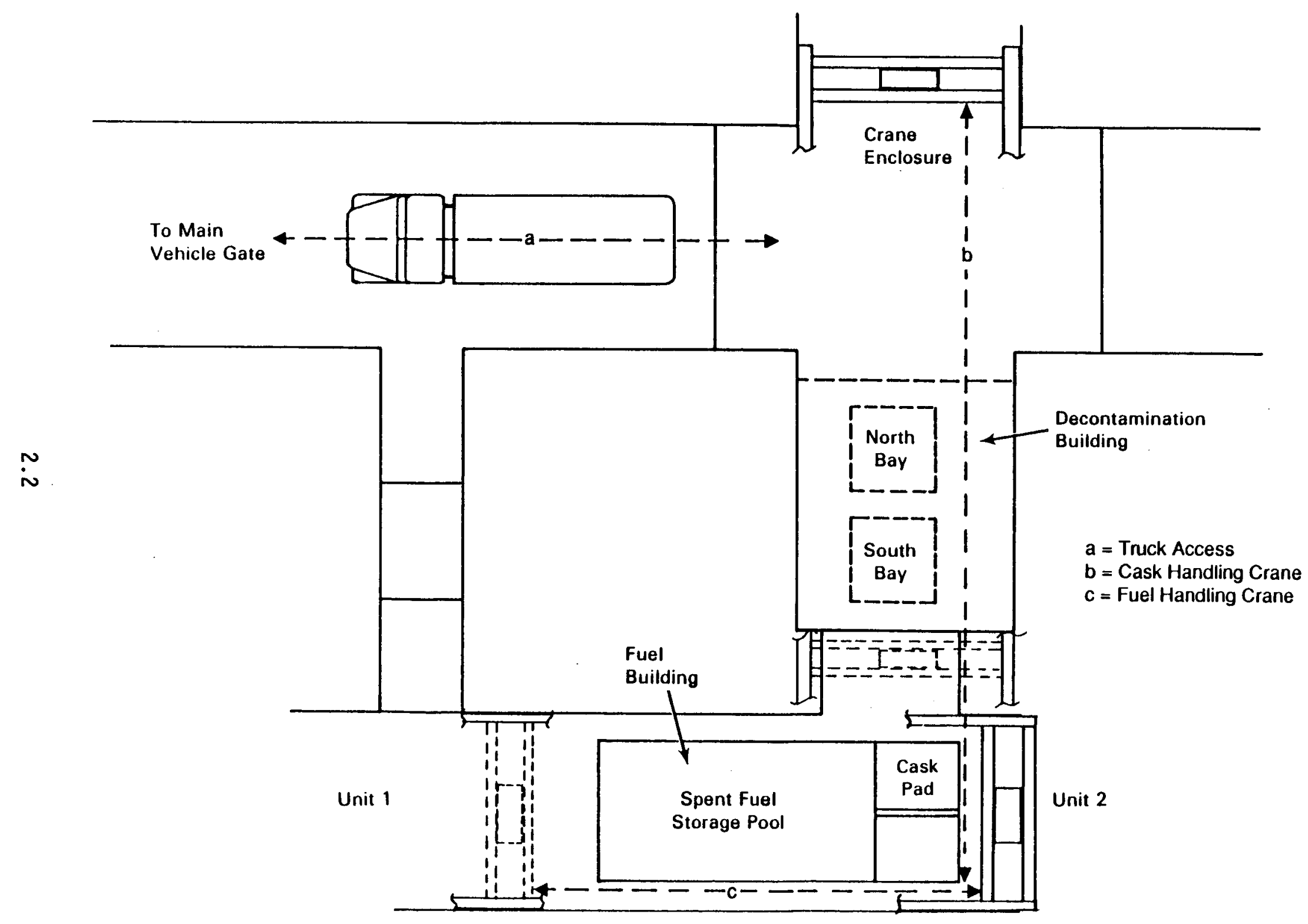

FIGURE 2.1. Cask-Handling Facilities at the Surry Nuclear Power Plant 
park. Because the crane must move along the orientation of the horizontal cask in order to upend the cask, the cask can only be removed in a horizontal position from the trailer.

The overhead crane then exchanges lifting yokes, and the cask is upended and transported to one of the bays in the Decontamination Building. After the cask is filled with water and the lid bolts are removed, the cask is moved to the Fuel Building. Inside the Fuel Building, the cask is placed on a submerged cask pad inside the pool for underwater spent-fuel-assembly loading operations. Following loading, the cask is decontaminated in the Decontamination Building and returned to the end of the Crane Enclosure Area for return to the transport vehicle.

For several years before spent fuel shipments were made, a concerted effort was made to improve the handling facilities at the Surry Power Station. These improvements included the following:

1. Enclose the outdoor areas of the 125-ton cask-handling crane to protect against inclement weather.

2. Segregate the cask preparation and testing area in the North Bay of the Decontamination Building with a concrete block wall to reduce background dose from adjacent rad-waste processing equipment.

3. Replace cask set-down pads in the east end of the spent fuel storage pool to mitigate damage to the pool in the event of accidental cask drop.

4. Clean and decontaminate the Fuel Building to allow access by personnel without protective clothing.

\subsubsection{Cask-Handling Operations}

Detailed cask-handling steps for at-reactor cask loading are provided in Appendix A. Major cask-handling activities are listed and then described below.

1. Conduct receipt inspections, transfer cask and trailer to yard tractor, and enter station to crane enclosure.

2. Remove cask protective and tiedown gear.

3. Perform horizontal lift of cask from trailer to tilting frame. 
4. Tilt cask to vertical and lift to preparation area in North Bay of decontamination building.

5. Prepare cask for loading, remove lid bolts, attach protective skirt, and fill cavity with water.

6. Move cask to fuel building.

7. Fill protective skirt with condensate water, and lower cask to bottom of spent fuel storage pool.

8. Load cask with fuel assemblies.

9. Remove cask from pool, install lid bolts, and drain water from protective skirt.

10. Move cask back to preparation area in the North Bay, and dry and decontaminate exposed outer surfaces.

11. Torque lid bolts, drain water from cavity, test for tightness and cavity dryness, and backfill cavity with nitrogen.

12. Remove protective skirt, and check for remaining contamination.

13. Move cask to tilting frame, and tilt to horizontal.

14. Perform horizontal lift of cask from tilting frame to trailer.

15. Insta11 cask protective and tiedown gear.

16. Complete dose rate surveys.

17. Exit station, and transfer to carrier's tractor.

18. Conduct State Police inspection, and Surry Power Station quality assurance (QA) inspection.

19. Complete and sign paperwork.

Activity 1 - Conduct Receipt Inspections, Transfer Cask and Trailer to Yard Tractor, and Enter Station to Crane Enclosure

After the empty shipping cask arrives at the main gate, the cask is surveyed for contamination, and the transport trailer is inspected. The bill of lading is signed, the tractor is disconnected from the trailer, and a yard tractor is connected. After a security search is performed, the cask is moved to the Crane Enclosure Area. 


\section{Activity 2 - Remove Cask Protective and Tiedown Gear}

At the Crane Enclosure Area, the personnel barrier is rolled back from the cask. The four trunnion impact 1 imiters and the two cask impact 1 imiters are then removed. T.wo front tiedown binders, are released, the trunnion guide assemblies are removed, and the rear tiedown collars are then removed.

\section{Activity 3 - Perform Horizontal Lift of Cask from Trailer to Tilting Frame}

The horizontal lift beam is attached to the cask, the cask is moved to the tilting frame, and the lift beam is removed and stored.

Activity 4 - Tilt Cask to Vertical and Lift to Preparation Area in the North Bay of Decontamination Building

The vertical lift beam is attached to the cask, and the cask is upended to the vertical position. The cask is then moved to the Decontamination Building.

Activity 5 - Prepare Cask for Loading, Remove Lid Bolts, Attach Protective Skirt, and Fill Cavity with Hater

The bottom cover is attached, the lift beam is unhooked, and the lid system is attached. Holes and rough surfaces are taped over and the protective skirt is attached: Skirt joints are then taped over. The "J" connectors are attached, and the cask is vented to atmospheric pressure. The "A" and " $\mathrm{C}$ " port $\mathrm{fl}$ anges are removed, and the cask is filled with water. The port flange gaskets are checked, and the lid bolts are removed.

\section{Activity 6 - Move Cask to Fuel Building}

The lift beam and lid lift system are attached, and the cask is moved to the Fuel Building.

\section{Activity 7- Fil1 Protective Skirt with Condensate Mater, and Lower Cask to Bottom of Spent-Fuel Storage Pool}

The skirt fill hose is connected, the cask is lowered into the pool, and the protective skirt is filled. The skirt drain hose is connected, and the fill hose is connected to the water box. The cask is lowered to the bottom of the pool, and the lift beam is released and raised. The lid gaskets are then checked. 


\section{Activity 8 - Load Cask with Fuel Assemblies}

Three PWR spent fuel assemblies are placed into the shipping cask.

Activity 9 - Remove Cask from Pool, Install Lid Bolts, and Drain Water from Protective Skirt

The lift beam is lowered, the lid is placed on the cask, and the lift beam is attached to the cask. After the cask is lifted to the pool surface, four lid bolts are installed hand tight. The lid lift system and the skirt drain hose are disconnected. The fill hose is connected to a gravity drain, and the cask is lifted, draining the skirt water. The lift beam and the cask are then rinsed with clean water, and the fill hose is disconnected from the cask.

Activity 10 - Move Cask Back to Preparation Area in North Bay, and Dry and Decontaminate Exposed Outer Surfaces

The cask is moved to the Decontamination Building and placed on the floor. The lift beam is disconnected, and the cask is dried and decontaminated.

Activity 11 - Torque Lid Bolts, Drain Water from Cask, Test for Tightness and Cavity Dryness, and Backfil1 Cavity with Nitrogen

All lid bolts are installed and torqued. Thermocouples are installed, and the lid is tested for tightness. The water in the cask is drained to a floor drain, and residual water is removed by a blow-down of the cavity. The cavity is then tested for dryness. Flange "A" is tested for tightness, and the cavity is backfilled with nitrogen. The cask is checked for contamination, and all tape is removed. Flanges "B, " $C$," and "D" are tested for tightness, the $J$ connectors are removed, and flanges are installed.

Activity 12 - Remove Protective Skirt, and Check for Remaining Contamination

The protective skirt is removed, and the fins are checked for contamination. The lift beam is then engaged, and the cask is lifted 1 foot. After the cask is lifted, the bottom cover is removed, and decontamination is completed. 


\section{Activity 13 - Move Cask to Tilting Frame, and Tilt to Horizontal}

The cask is moved to the tilting frame, and the rear trunnion supports on the tilting frame are lubricated. After the cask is lowered in the tilting frame, the lift beam is disengaged and stored. The cask is checked for contamination, dose rates are measured, and the trailer is moved to the center of the Cask Enclosure Area.

\section{Activity 14 - Perform Horizontal Lift of Cask from Tilting Frame to Trailer}

The horizontal lift beam is engaged and attached to the cask. The cask is raised above the protective cover and lowered onto the trailer. The horizontal beam is then disengaged and stored.

\section{Activity 15 - Install Cask Protective and Tiedown Gear}

The rear tiedown collars and front tiedown binders are installed. The trunnion guide assembly is then installed. The cask impact limiters and the trunnion impact limiters are installed, and the protective cover is rolled out. Security seals are then attached.

\section{Activity 16 - Complete Dose Rate Surveys}

A dose rate survey of the cask is completed in the Crane Enclosure Area. Activity 17 - Exit Station, and Transfer to Carrier's Tractor

The yard tractor pulls the trailer through Gate 1 to the Tri-State Motor Transit tractor. The yard tractor is disconnected, and the Tri-State tractor is connected to the trailer.

Activity 18 - Conduct State Police Inspection, and the Surry Power Station QA Inspection

The State Police and Surry Power Station QA inspections are performed. The rear of the protective cover is then closed, and the cover tiedown cords are attached.

\section{Activity 19 - Complete and Sign Paperwork}

After the paperwork is completed, the shipment is released. 


\subsubsection{Staffing Requirements for Reactor Cask-Handling}

Surry Power Station staffing requirements and responsibilities for $\mathrm{TN}-8 \mathrm{~L}$ shipments are shown in Table 2.1. Support was provided by Virginia Power corporate staff in the areas of interface with the cask owner and regulatory agencies, fuel selection, scheduling, and problem resolution. A matrix showing the relationship among all the involved parties is shown in Figure 2.2.

Most cask-handling is performed by Surry Power Station operations personnet, formed in a six-man team with a shift supervisor and five operators. Most of the members of the team have Reactor Operator Licenses. The team works one 10-hour shift per day, 7 days a week if needed.

\subsubsection{Reactor Shipping Cask-Handling Times}

The handling time for each major step is shown in Table 2.2. These data were taken during shipment number 20 ; therefore, personnel were very familiar with each task and their effectiveness was optimized.

\section{TABLE 2.1. Staffing Requirements}

\begin{tabular}{llll}
\multicolumn{1}{c}{ Category } & \multicolumn{1}{c}{ Personnel } & & \multicolumn{1}{c}{ Responsibilities } \\
\cline { 1 - 1 } Operations & $\begin{array}{l}1 \text { Shift Supervisor } \\
5 \text { Operators }\end{array}$ & Crane movements, most hands-on work \\
Quality Control & $\begin{array}{l}1 \text { Inspector } \\
\text { (part-time) }\end{array}$ & $\begin{array}{l}\text { Calibrate test equipment and tools; } \\
\text { cask testing results; verify loadin } \\
\text { of fue1 assemblies; inspect vehicle }\end{array}$ \\
Health Physics & $\begin{array}{l}1 \text { Assistant Supervisor } \\
1-3 \text { Technicians } \\
2-3 \text { Decontamination }\end{array}$ & $\begin{array}{l}\text { Conduct dose rate surveys; cask } \\
\text { decontamination; housekeeping }\end{array}$ \\
Engineering & $\begin{array}{l}\text { Techs. (all part-time) } \\
\text { Security }\end{array}$ & 2 Officers (part-time) & $\begin{array}{l}\text { Inspect vehicles; provide station } \\
\text { access for vehicies }\end{array}$ \\
Construction & 1 Driver (part-time) & Provide onsite cask and trailer \\
movements & & $\begin{array}{l}\text { Resolve problems; schedule vendor } \\
\text { interfaces }\end{array}$
\end{tabular}




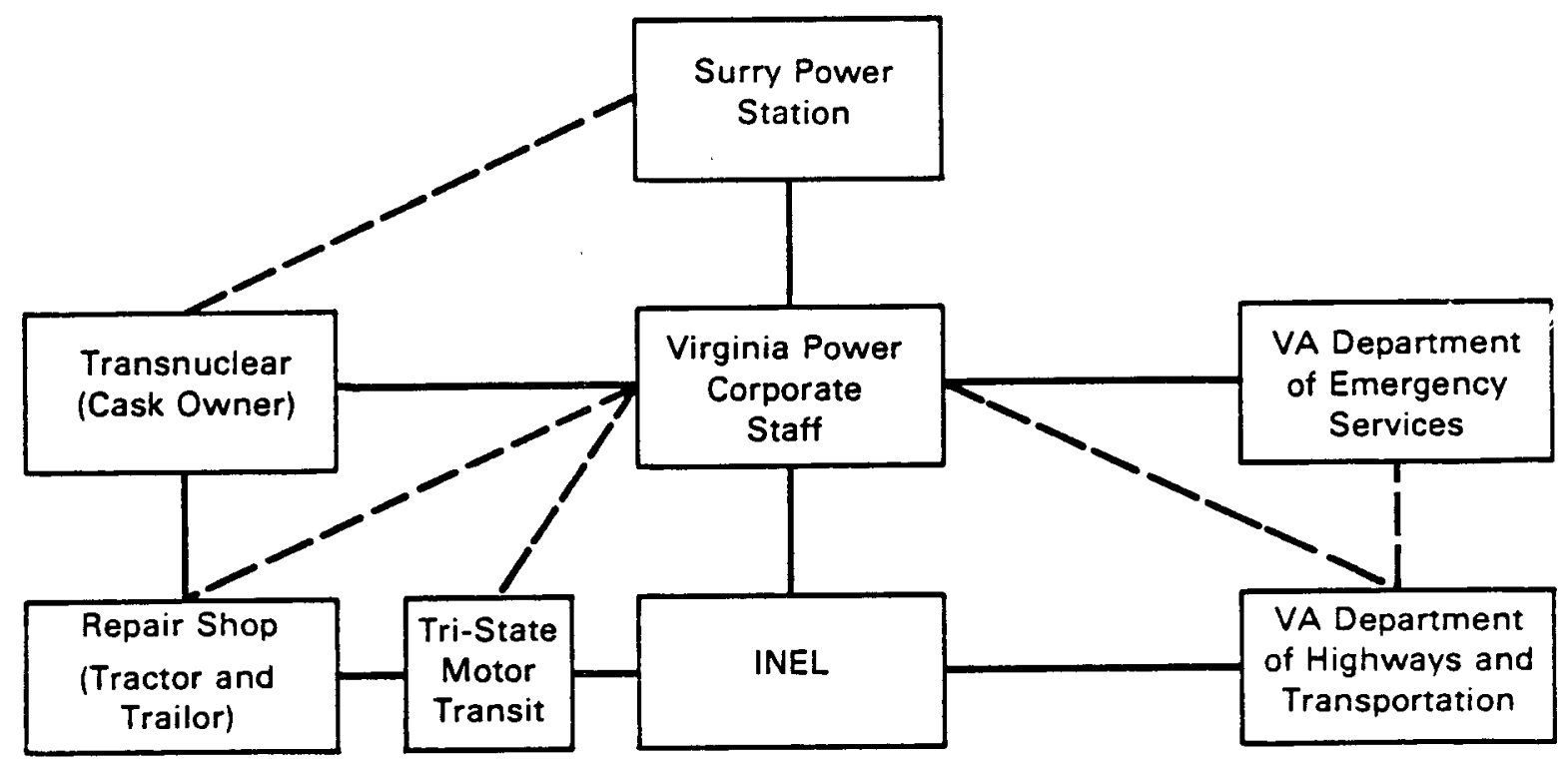

FIGURE 2.2. Organization Matrix for TN-8L Shipments

The total handling time of 14 hours, 7 minutes is the actual handling time and is not the cask turnaround time at the reactor. Total turnaround time, including delays due to equipment and crew unavailability, is shown in Table 2.3, which shows the total time for the 23 shipments. As Table 2.3 shows, total time for shipment number 20 was 3 days.

Improved handling efficiency at the Surry Power Station and at INEL can be observed. Series 2 and 3 were made following the route shown in Figure 1.1. In addition to improving travel time, handling times were improved by up to $50 \%$ as personnel became more familiar with cask operations. In some instances, fabrication of customized tools decreased the time needed for particular steps by factors of 4 to 5 .

Several shipments were delayed because of problems encountered during loading operations. These problems are summarized below:

- minor malfunction of the 125-ton cask-handling crane

- equipment malfunctions of the carrier's tractor

- minor structural cracks in the trailer

- "weeping" of contamination from the cask 
TABLE 2.2. Reactor Shipping Cask Handling Times

Elapsed

Time

Activity

(minutes)

1. Conduct receipt inspections, transfer cask and trailer to yard tractor, and enter station to crane enclosure

2. Remove cask protective and tiedown gear 30

3. Perform horizontal lift of cask from trailer to tilting frame 15

4. Tilt cask to vertical and lift to preparation area in North Bay of decontamination building

5. Prepare cask for loading, remove lid bolts, attach protective skirt, and fill cavity with water

6. Move cask to fuel building

7. Fill protective skirt with condensate water, and lower cask to bottom of spent fuel storage pool

8. Load cask with fuel assemblies

9. Remove cask from pool, install lid bolts, and drain water from protective skirt

10. Move cask back. to preparation area in North Bay, and dry and decontaminate exposed outer surfaces

11. Torque 1id bolts, drain water from cavity, test for tightness and cavity dryness, and backfill cavity with nitrogen

12. Remove protective skirt, and check for remaining contamination 35

13. Move cask to tilting frame, and tilt to horizontal 47

14. Perform horizontal lift of cask from tilting frame to trailer 45

15. Install cask protective and tiedown gear 20

16. Complete dose rate surveys 15

17. Exit station, and transfer to carrier's tractor 25

18. Conduct State Police inspection, and Surry QA inspection 15

19. Complete and sign paperwork

TOTAL 
- tearing of the cask protective cover on the trailer

- protective skirt fill and drain hoses snagging on other equipment when lowering or raising the cask from the spent fuel storage pool

- inadequate retraction of the lift beam arms when detaching from the cask

- difficulty attaching shock absorbing covers to the cask

- difficulty coordinating the schedule for different crafts.

Some of these problems were unexpected and could not have been prevented. others, especially those involving equipment malfunctions, could have been prevented or mitigated by improved inspection and maintenance.

TABLE 2.3. Total Travel and Turnaround Time (days)(a)

\begin{tabular}{|c|c|c|c|c|c|c|}
\hline & $\begin{array}{c}\text { Shipment } \\
\text { No. } \\
\end{array}$ & $\begin{array}{l}\text { Load } \\
\text { Time }\end{array}$ & $\begin{array}{c}\text { Trave1 } \\
\text { Time }\end{array}$ & $\begin{array}{l}\text { Unloading } \\
\text { Time }\end{array}$ & $\begin{array}{l}\text { Trave } \\
\text { Time (b) }\end{array}$ & $\begin{array}{l}\text { Total } \\
\text { Time } \\
\end{array}$ \\
\hline \multirow[t]{2}{*}{ Series 2} & $\begin{array}{r}8 \\
9 \\
10 \\
11 \\
12 \\
13 \\
14 \\
15\end{array}$ & $\begin{array}{l}3.0 \\
3.0 \\
3.0 \\
6.0 \\
2.5 \\
3.0 \\
3.5 \\
\underline{6.5}\end{array}$ & $\begin{array}{l}3.0 \\
3.0 \\
3.0 \\
3.0 \\
3.5 \\
3.0 \\
3.0 \\
3.0 \\
\end{array}$ & $\begin{array}{l}3.0 \\
2.0 \\
4.0 \\
2.0 \\
1.5 \\
2.0 \\
5.0 \\
2.0 \\
\end{array}$ & $\begin{array}{l}3.0 \\
4.0 \\
2.5 \\
3.0 \\
2.5 \\
2.5 \\
\text { N/A } \\
\text { N/A }\end{array}$ & $\begin{array}{l}12.0 \\
12.0 \\
12.5 \\
14.0 \\
10.5 \\
11.5 \\
11.5 \\
11.5 \\
\end{array}$ \\
\hline & Average & 3.8 & 3.1 & 2.7 & 2.9 & 12.5 \\
\hline Series 3 & $\begin{array}{l}16 \\
17 \\
18 \\
19 \\
20(c) \\
21 \\
22 \\
23\end{array}$ & $\begin{array}{l}3.0 \\
3.0 \\
2.5 \\
3.0 \\
3.0 \\
4.5 \\
3.0 \\
2.5 \\
\end{array}$ & $\begin{array}{l}3.0 \\
3.0 \\
3.0 \\
3.0 \\
3.0 \\
2.5 \\
3.0 \\
2.5 \\
\end{array}$ & $\begin{array}{l}3.0 \\
2.0 \\
1.5 \\
2.5 \\
1.5 \\
1.5 \\
2.0 \\
3.0 \\
\end{array}$ & $\begin{array}{l}2.5 \\
3.0 \\
2.5 \\
2.5 \\
2.5 \\
2.5 \\
\text { N/A } \\
\text { N/A }\end{array}$ & $\begin{array}{r}11.5 \\
11.0 \\
9.5 \\
11.0 \\
10.0 \\
11.0 \\
8.0 \\
10.6 \\
\end{array}$ \\
\hline & Average & 3.1 & 2.9 & 2.1 & 2.6 & 10.6 \\
\hline
\end{tabular}

(a) Percent Improvement, Series 2 to Series $3=15 \%$

(b) $\mathrm{N} / \mathrm{A}=$ not available.

(c) Shipment followed 
Complete "readiness reviews" must be performed to eliminate equipment malfunctions to the extent possible. In particular, vendor-supplied equipment must be inspected and vendor maintenance programs monitored to ensure their adequacy.

Lastly, staff independent of the handling operation are needed to coordinate and monitor vendor activities, to monitor the schedule for incoming, empty casks to ensure personnel readiness, and to coordinate communications with regulatory agencies.

\subsection{DOSE EVALUATION OF REACTOR CASK-HANDLING}

A cask dose rate map for shipment number 20 is shown in Figure 2.3. The maximum cask surface dose rate for each shipment is shown in Table 2.4. Wide variations in the cooling times, discharge burnups, and number of curies resulted in a comparable wide variation in surface dose rates. Background dose rates for the three working areas are shown in Table 2.5.

Personnel dose by activity is shown by Table 2.6. The loading of the TN-8L cask resulted in 136 person-mrem of exposure. The highest dose producing activity is Activity 11 , consisting of all activity steps from torquing lid bolts through backfilling the cavity with nitrogen. Activity 11 contributes 37.00 person-mrem, or $27 \%$ of total dose.

Personnel dose by source is shown in Table 2.7. As the table shows, over $72 \%$ of personnel dose is from background radiation. Only 38 person-mrem of exposure is from doses received from the cask. Of the 98 person-mrem of exposure received from background radiation, $44 \%$ is received in the Decontamination Building, $52 \%$ is received in the Fuel Building, and the remaining $4 \%$ is received in the Crane Enclosure Area.

Clearly, background dose contributed the major portion of total dose (72\%); therefore, efforts to reduce total personnel exposure should be directed towards this source. Background dose can best be reduced by optimizing design efforts to prevent colocation of sources without the proper shielding. Also, good housekeeping and maintenance practices should be stressed to prevent accumulation of background sources. Finally, access to 


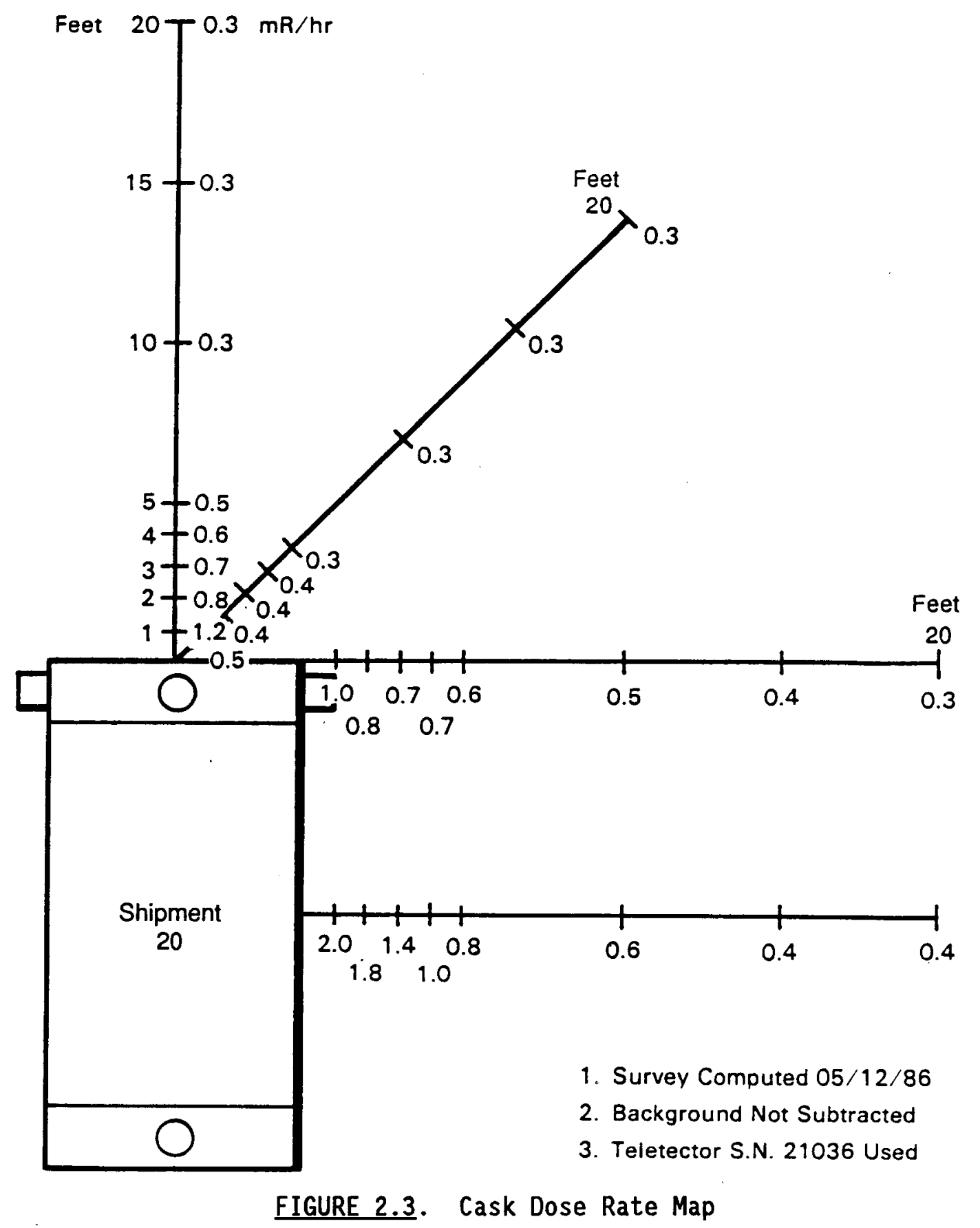

working areas should be carefully coordinated to ensure that only those persons with tasks to perform are spending the minimum time needed in restricted areas. 
IABLE 2.4. Cask Surface Dose Rates(a)

\begin{tabular}{|c|c|c|c|c|}
\hline Shipment No. & $\begin{array}{l}\text { Cooling } \\
\text { Time } \\
(y r) \\
\end{array}$ & $\begin{array}{l}\text { Average } \\
\text { Burnup } \\
\text { (MWD/MTU) }\end{array}$ & $\begin{array}{l}\text { Activity } \\
\text { or Fuel } \\
\text { (curies) }\end{array}$ & $\begin{array}{c}\text { Maximum } \\
\text { Surface } \\
\text { Dose Rate } \\
\text { (mrem/hr) }\end{array}$ \\
\hline $\begin{array}{r}1 \\
2 \\
3 \\
4 \\
5 \\
6 \\
7 \\
8 \\
9 \\
10 \\
11 \\
12 \\
13 \\
14 \\
15 \\
16 \\
17 \\
18 \\
19 \\
20 \\
21 \\
22 \\
23\end{array}$ & $\begin{array}{l}3.5 \\
3.5 \\
3.5 \\
2.5 \\
2.5 \\
2.5 \\
2.5 \\
4.0 \\
4.0 \\
4.0 \\
4.0 \\
4.0 \\
4.0 \\
4.0 \\
4.0 \\
9.0 \\
10.0 \\
9.0 \\
9.0 \\
9.0 \\
7.0 \\
4.5 \\
7.5\end{array}$ & $\begin{array}{l}33,000 \\
34,000 \\
33,000 \\
32,000 \\
32,000 \\
32,000 \\
32,000 \\
31,000 \\
31,000 \\
30,000 \\
30,000 \\
30,000 \\
30,000 \\
30,000 \\
30,000 \\
25,000 \\
27,000 \\
30,000 \\
30,000 \\
30,000 \\
33,000 \\
28,000 \\
33,000\end{array}$ & $\begin{array}{r}996,950 \\
1.017,000 \\
992,900 \\
1.426,900 \\
1.426,900 \\
1,426,900 \\
1,426,900 \\
876,400 \\
85,500 \\
847,800 \\
845,400 \\
845,400 \\
839,800 \\
839,800 \\
839,800 \\
459,900 \\
464,400 \\
536,600 \\
536,600 \\
639,600 \\
639,600 \\
740,400 \\
624,900\end{array}$ & $\begin{array}{r}13.0 \\
12.5 \\
12.5 \\
22.5 \\
22.6 \\
21.0 \\
23.8 \\
N / A \\
N / A \\
9.8 \\
9.8 \\
10.0 \\
9.0 \\
8.4 \\
8.2 \\
4.0 \\
6.0 \\
8.0 \\
7.0 \\
6.5 \\
10.0 \\
6.8 \\
8.0\end{array}$ \\
\hline
\end{tabular}

(a) Bold letters indicate shipment followed.

TABLE 2.5. Background Dose Rates

1. Crane Enclosure

- 0.1 to $1.2 \mathrm{mrem} / \mathrm{hr}$

- $0.25 \mathrm{mrem} / \mathrm{hr}$ average

2. North Bay Decontamination Building

- 5.0 to $100 \mathrm{mrem} / \mathrm{hr}$

- $5.0 \mathrm{mrem} / \mathrm{hr}$, top of scaffold around cask

- $7.0 \mathrm{mrem} / \mathrm{hr}$, floor

3. Fuel Building, Spent Fuel Storage Pool

- 1.0 to $70 \mathrm{mrem} / \mathrm{hr}$

- $5.0 \mathrm{mrem} / \mathrm{hr}$, deck around cask-handling area 
TABLE 2.6. Personnel Dose by Activity

Personne1 Dose

(person-mrem)

1. Conduct receipt inspections, transfer cask and trailer

0.00 to yard tractor, and enter station to the Crane Enclosure Area.

2. Remove cask protective and tiedown gear.

3. Perform horizontal lift of cask from trailer to tilting frame.

4. Tilt cask to vertical and lift to preparation area in North Bay of the Decontamination Building.

5. Prepare cask for loading, remove lid bolts, attach protective skirt, and fill cavity with water.

6. Move cask to the Fuel Building.

7. Fill protective skirt with condensate water, and lower cask to bottom of spent fuel storage pool.

8. Load cask with fuel assemblies.

9. Remove cask from pool, install lid bolts, and drain 22.70 water from protective skirt.

10. Move cask back to preparation area in North Bay, and dry and decontaminate exposed outer surfaces.

11. Torque lid bolts, drain water from cavity, test for tightness and cavity dryness, and backfill cavity with nitrogen.

12. Remove protective skirt, and check for remaining contamination.

13. Move cask to tilting frame, and tilt to horizontal.

14. Perform horizontal lift of cask from tilting frame to trailer.

15. Install cask protective and tiedown gear.

16. Complete dose rate surveys.

17. Exit station, and transfer to the carrier's tractor.

18. Conduct State Police inspection, and Surry Power Station QA inspection.

19. Complete and sign paperwork. 
TABLE 2.7. Personnel Dose by Location

\begin{tabular}{|c|c|c|c|}
\hline Location & $\begin{array}{l}\text { Background } \\
\text { Dose } \\
\text { (person-mrem) }\end{array}$ & $\begin{array}{c}\text { Cask Dose } \\
\text { (person-mrem) }\end{array}$ & $\begin{array}{l}\text { Total Dose } \\
\text { (person-mrem) }\end{array}$ \\
\hline $\begin{array}{l}\text { Crane Enclosure Area } \\
\text { (empty) }\end{array}$ & 1.40 & 0.00 & 1.40 \\
\hline $\begin{array}{l}\text { Decontamination Building } \\
\text { (empty) }\end{array}$ & 18.73 & 0.00 . & 18.73 \\
\hline Fuel Building & 51.64 & 0.30 & 51.34 \\
\hline $\begin{array}{l}\text { Decontamination Building } \\
\text { (l loaded) }\end{array}$ & 52.54 & 28.67 & 23.87 \\
\hline \multirow{2}{*}{$\begin{array}{l}\text { Crane Enclosure Area } \\
\text { (loaded) }\end{array}$} & 11.31 & 8.75 & 2.56 \\
\hline & $135.62(a)$ & 37.72 & 97.90 \\
\hline
\end{tabular}

(a) Background is $72 \%$ of total dose. 


\subsection{IN-TRANSIT ASSESSMENT}

The in-transit data collected during the spent fuel shipment are discussed in this chapter. Included in this discussion is a description of the route followed, in-transit data (e.g., hourly vehicle counts, population zones, etc.), stops data (e.g., type of stop, duration of stop, approximate number of individuals exposed, etc.), and the calculated occupational and public doses.

The shipment departed from the Surry Power Station on Apri1 24, 1986, and arrived at the TAN Facility on April 26, 1986. The total distance traveled was approximately 2807 miles, following the route shown in Figure 1.1. The total time required for this demonstration was approximately 62 hours, including 6.4 hours for stops. The average speed was approximately 50 miles per hour. The special regulations applicable to nonstandard shipments and shipments of radioactive materials that follow the route were discussed in Section 1.2.2.

The following sections discuss observations that were noted during transit (in-transit data) and while the shipment was delayed (stops data). Time delays that were encountered enroute as a result of the escort requirements, 2-hour call-ins, or DOT inspections were recorded and are discussed in the stops-data section.

\subsection{IN-TRANSIT DATA}

This section discusses the in-transit data collected while the TN-8L shipment was being observed. In-transit data includes data collected while the vehicle was moving. The types of data collected included the total mileage traveled, the various population zones encountered, and the number of vehicles on the road and in rest areas or weigh stations.

The mileage was recorded for each observation (see Appendix B). It was determined that the time of the observation would not be required. The time, if necessary for future studies, can be reasonably estimated based on the average truck speed. Mileage is used in a subsequent section to calculate public doses based on the average number of vehicles per mile and on the 
average number of vehicles in rest areas and weigh stations, and to determine the percentage of the total distance for each population zone.

Vehicles traveling in the same direction and in the opposite direction were counted on an hourly basis (Table 3.1). Vehicles that are identified as traveling in the same direction were counted as they passed the $\mathrm{TN}-8 \mathrm{~L}$ shipment. No distinction was made during data collection as to whether the vehicle was traveling on a two-lane or four-lane highway. Approximately $95 \%$ of the highways traveled had four lanes. Two-lane highways were used in Virginia when leaving the Surry Power Station and at the Utah/Idaho border. The number of vehicles stopped at rest areas and in weigh stations, while the shipment was moving, were also counted. The number of vehicles stopped in the opposing 1 ane was 202 and in the same lane or direction was 274 .

The distances traveled through the respective population zones also were recorded (see Table 3.2). It was determined that the rural zone represented populations of 10,000 or less, that the suburban zone represented populations greater than 10,000 and less than 30,000 and that the urban zone represented populations greater than 30,000 . Areas exhibiting high population densities, such as office buildings and commercial facilities were also recorded as

TABLE 3.1. Summary of In-Transit Data: Vehicle Counts

\begin{tabular}{|c|c|c|}
\hline Direction of Vehicles & $\begin{array}{l}\text { Lanes of } \\
\text { Iraffic }\end{array}$ & $\begin{array}{l}\text { Number of } \\
\text { Vehicles }\end{array}$ \\
\hline $\begin{array}{l}\text { Vehicles traveling in } \\
\text { the same direction }\end{array}$ & 2 or 4 & $113(a)$ \\
\hline $\begin{array}{l}\text { Vehicles traveling in } \\
\text { the opposite direction }\end{array}$ & $\begin{array}{l}2 \\
4\end{array}$ & $\begin{array}{r}168(a) \\
1510(a)\end{array}$ \\
\hline $\begin{array}{l}\text { Vehicles parked in } \\
\text { the same direction }\end{array}$ & 2 or 4 & $274^{(b)}$ \\
\hline $\begin{array}{l}\text { Vehicles parked in } \\
\text { the opposite direction }\end{array}$ & $\begin{array}{l}2 \\
4\end{array}$ & $\begin{array}{r}10(\mathrm{~b}) \\
192(\mathrm{~b})\end{array}$ \\
\hline
\end{tabular}

(a) Summation of the 34 hourly vehicle counts.

(b) Totals for the entire shipment. 
IABLE 3.2. Summary of In-Transit Data: Population Zones

\begin{tabular}{|c|c|c|c|c|}
\hline Population & Zone & $\begin{array}{c}\text { Population } \\
\text { Density }\left(\mathrm{p} / \mathrm{m}^{2}\right)\end{array}$ & $\begin{array}{l}\text { Segment } \\
\text { Length (m) }\end{array}$ & $\begin{array}{l}\text { Percentage } \\
\text { of Total }\end{array}$ \\
\hline 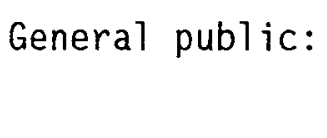 & $\begin{array}{l}\text { Rural } \\
\text { Suburban } \\
\text { Urban }\end{array}$ & $\begin{array}{l}8.50 \mathrm{E}-06 \\
6.90 \mathrm{E}-05 \\
1.60 \mathrm{E}-03\end{array}$ & $\begin{array}{l}3.99 E+06 \\
4.34 E+05 \\
8.05 E+04\end{array}$ & $\begin{array}{r}88 \\
10 \\
2\end{array}$ \\
\hline
\end{tabular}

urban populations. Table 3.2 shows that $88 \%$ of the total miles traveled were in rural zones, $10 \%$ were in suburban zones, and $2 \%$ were in urban zones.

\subsection{STOPS DATA}

Data were also collected each time the vehicle stopped at a weigh station, rest area, or truck stop. The types of data collected included the reason for the stop, the date, the mileage, the time in and time out or the elapsed time, and general observations, such as the number of vehicles or people in the immediate area. Sketches were also made of representative stops showing the locations and distances of occupied buildings, and other vehicles with respect to the TN-8L shipping cask.

Data were collected on Stops Data Sheets, which are shown in Appendix $B$ (Section B.3). The data are summarized in Appendix B and Table 3.3. Twentysix stops were made in the 62-hour period for a total of approximately 6 hours, 24 minutes.

In-transit stops represent the greatest potential for dose reductions to the public; therefore, the following sections will discuss each type of stop identified in Table 3.3.

\subsubsection{Weigh Stations}

Nine stops were made at weigh stations. The total elapsed time for these nine stops was approximately 1 hour, 26 minutes. These stops included a 45-minute stop at the Tennessee border and one stop at a toll booth. The extended stop at the Tennessee border was the result of the Tennessee State DOT inspection of the tractor and trailer, a requirement discussed in Section 1.2 .2 . 
TABLE 3.3. Summary of Stops Data

\begin{tabular}{|c|c|c|c|c|}
\hline Category of Stop & $\begin{array}{l}\text { Number of } \\
\text { Stops } \\
\end{array}$ & $\begin{array}{l}\text { People at } \\
\text { Stops }(a)^{\text {t }}\end{array}$ & $\begin{array}{l}\text { Vehicies } \\
\text { at Stops }\end{array}$ & $\begin{array}{l}\text { Avg. Hours } \\
\text { at Stops }\end{array}$ \\
\hline $\begin{array}{l}\text { Weigh Station } \\
\text { (Tenn. DOT) (b) } \\
\text { (c) }\end{array}$ & $\begin{array}{l}9 \\
1 \\
1\end{array}$ & $\begin{array}{l}2 \\
1 \\
1\end{array}$ & 33 & $\begin{array}{l}0.08 \\
0.75 \\
0.05\end{array}$ \\
\hline Rest Area & 5 & & 49 & 0.13 \\
\hline $\begin{array}{l}\text { Truck Stops }(d) \\
\text { Other vehicles fueling } \\
\text { Other vehicles parked }\end{array}$ & 9 & 284 & 31 & 0.41 \\
\hline Badge House & 2 & 5 & & 0.29 \\
\hline
\end{tabular}

(a) People in vehicles not included.

(b) Tennessee DOT Inspector.

(c) Vehicle inspection.

(d) A restaurant stop.

The actual time required to weigh the vehicle was approximately 2 minutes. The remaining time included waiting in line, waiting for the escort vehicle in Wyoming, or waiting to obtain state highway permits. A typical weigh station is shown in Figure 3.1 .

\subsubsection{Rest Area}

The truck drivers were required by contract to periodically "call-in" to a central office and report the location of the shipment. The truck was equipped with a mobile phone, and "call-ins" were normally made in transit. However, "dead spots" or areas not servicing mobile communications were encountered. In these "dead spots," the driver had to stop to complete the "call-in." If possible, these calls were made during refueling, at weigh stations, or at rest areas. Three stops were made specifically to "call-in" and required less than 3 minutes each or a total of 8 minutes. Because of the severe weather conditions in $0 \mathrm{klahoma}$, an extended rest stop (20 minutes) was made to obtain an updated weather report. 


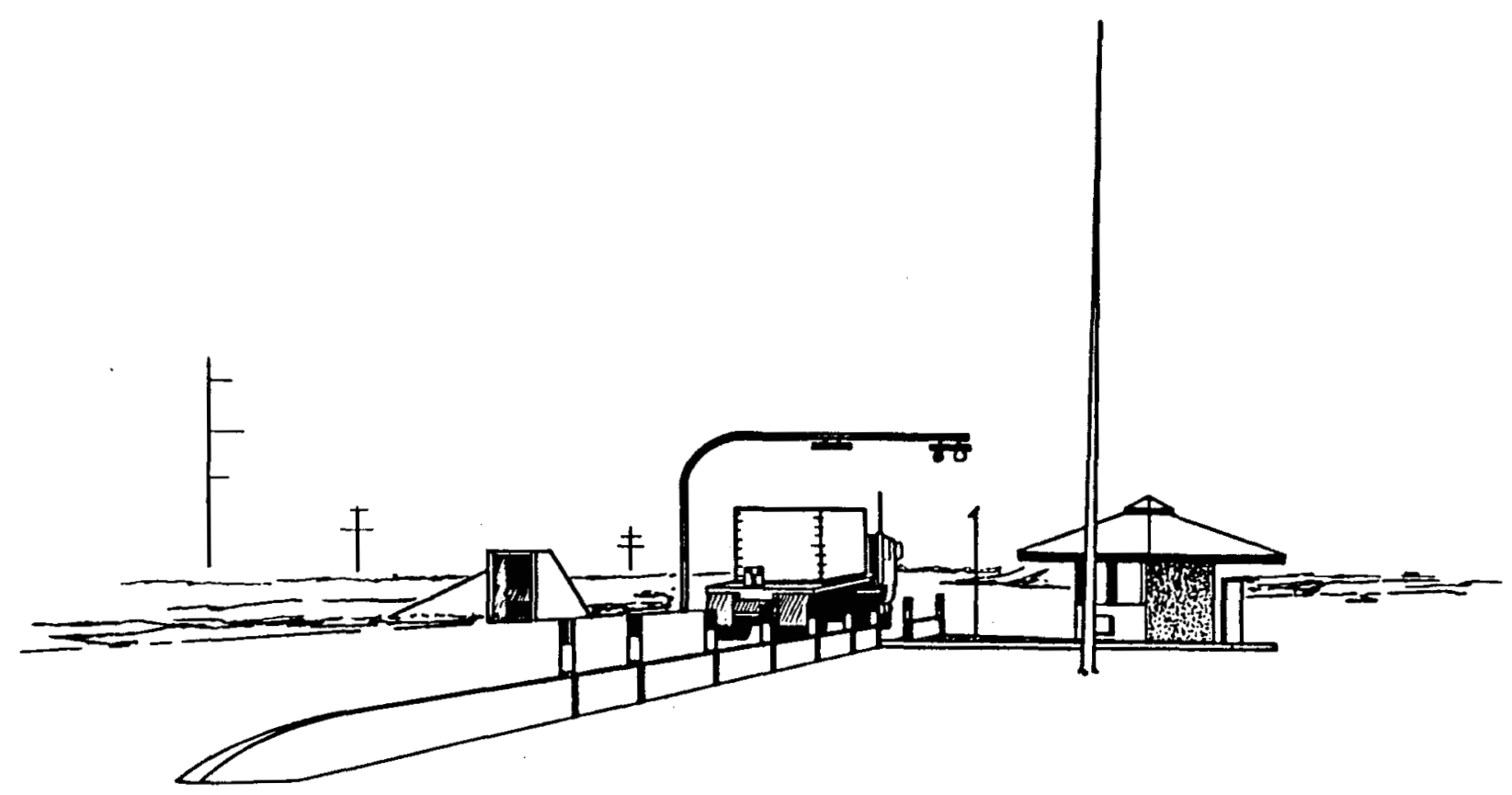

FIGURE 3.1. Typical Weigh Station

\subsubsection{Truck Stops}

Eight refueling stops were made enroute from the Surry Power Station to the TAN Facility at INEL. The total elapsed time for refueling was approximately 3 hours, 25 minutes, including a 60 -minute stop to refuel and repair a rear-axle bearing. The truck fuel tanks were filled at each of these stops, which averaged approximately 25 minutes each. At all of these stops, at least one driver was in the immediate vicinity of the shipping cask at all times. A typical refueling stop is shown in Figure 3.2.

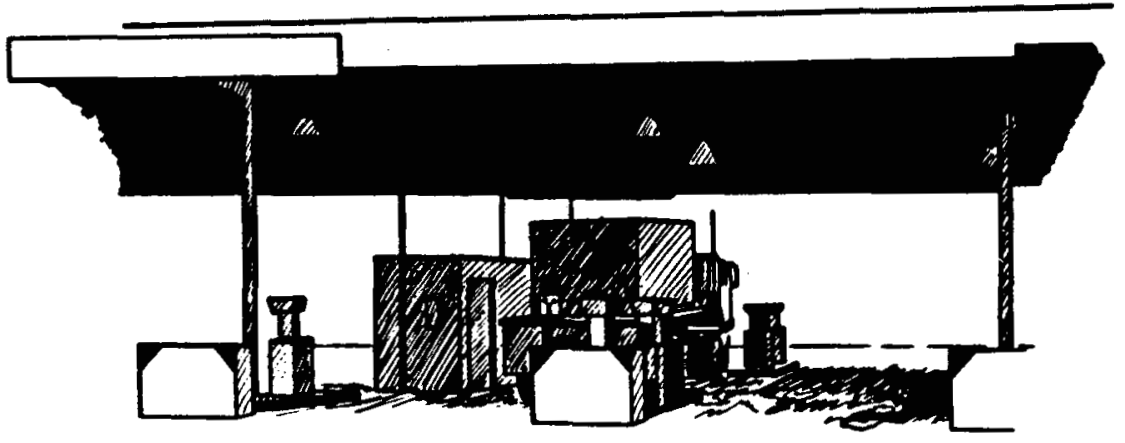

FIGURE 3.2. A Typical Refueling Stop 
When available, the drivers used self-service pumps when refueling the truck to reduce shipping costs. At most truck stops, the self-service pumps were located at the furthest islands from the truck stop buildings and overnight parking area. Because the pumps are usually located at the outermost islands, radiological doses to the public inside the truck stops, those parked overnight in their vehicles, and those in queue at the other pump islands were reduced. One of the stops included in the Truck Stops category in Table 3.3 was at a restaurant. This stop required approximately 28 minutes, during which one driver remained with the shipment.

The actual dose received by the public during truck refueling stops is small (see Section 3.3), although the perceived dose to the public during refueling stops is high.

\subsubsection{Badge House}

It was necessary to stop at the INEL Badge House for about. 20 minutes to obtain temporary badges to continue following the shipment to the TAN facility. It was also necessary to obtain temporary badges to enter the TAN facility. This badging process required about 15 minutes. The shipment was then allowed to enter the facility, and the trailer was unhooked from the tractor.

\subsection{IN-TRANSIT DOSE EVALUATION}

This section presents the estimated dose to the public encountered during the shipment. Included are doses to persons in vehicles traveling in the same direction or in the opposite direction; persons in rest areas, weigh stations, and truck stops; and the general public. The dose to the general public was based on the population densities for each type of population zone encountered. The doses were estimated based on the dose rate maps for a loaded TN-8L shipping cask. The dose rate maps were provided by Virginia Power.

\subsubsection{In-Transit Dose Estimates}

A description of the detailed dose calculations is provided in Appendix $C$. These calculations were used to estimate the dose to the public for 
vehicles traveling in the same direction and in opposite direction, and in weigh stations, rest areas, and truck stops.

An average surface dose factor for the sides of the cask was used when performing the calculations. This factor, $10 \mathrm{mrem} / \mathrm{hr} \mathrm{m}^{2}$, is based on the dose rate map provided by Virginia Power and corresponds to a TN-8L cask loaded with three 10-year-old PWR spent fuel assemblies.

\section{Calculated Public Doses}

The dose to the public in vehicles encountered during the shipment was calculated using the formula described in Greenborg et al. (1980) and detailed in Appendix C. The distances separating the cask from other vehicles on the highway are shown in Figure 3.3. The distances used to calculate the dose to the public in vehicles are shown in Table 3.4.

Vehicle counts that included vehicles traveling on the interstate or highway and vehicles parked at rest areas or weigh stations were taken during

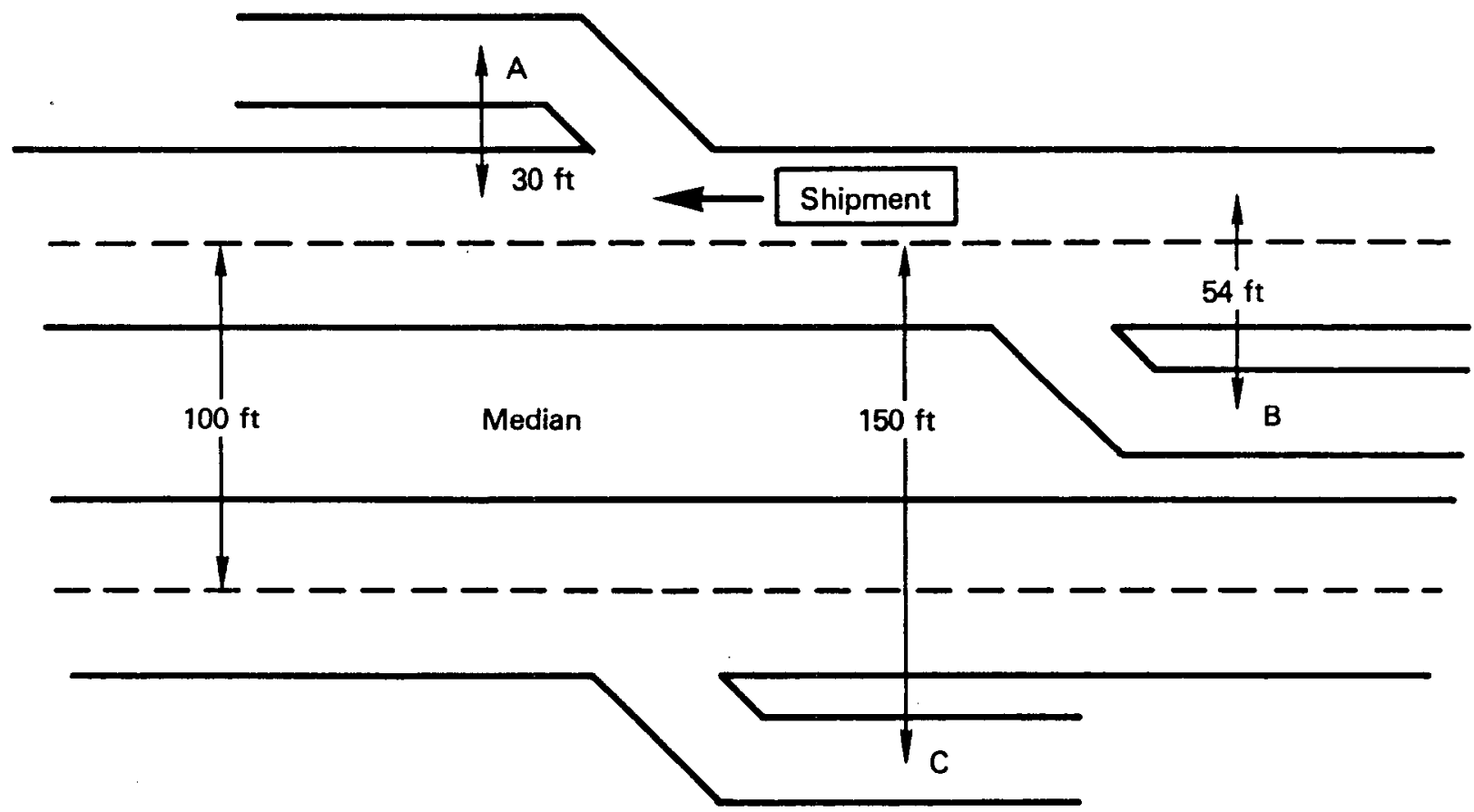

A - Rest Area or Weigh Station in Same Direction 2 or 4-Lane

B - Rest Area or Weigh Station in Opposite Direction 2-Lane

C - Rest Area or Weigh Station in Opposite Direction 4-Lane

FIGURE 3.3. Typical Dimensions of 4-Lane Interstate (feet) 
TABLE 3.4. Distances Used to Calculate the In-Transit Dose to the Public

\section{Location of Vehicles}

Two-Lane Highways

Vehicles encountered

Weigh stations and rest areas

Four-Lane Highways/Interstates

Vehicles encountered

Weigh stations and rest areas

\author{
Distances Used to Calculate \\ Public Doses (feet) \\ Opposing Direction
}

8

30

the trip. As stated previously, data were not collected on whether the vehicles were traveling on a two-lane or four-lane highway; therefore, the vehicle counts shown in Table 3.5 have been adjusted to reflect the percentage of miles traveled on two-lane or four-lane highways (90\% four 1 ane and $10 \%$ two lane). To calculate the dose to the public, an average vehicle

TABLE 3.5. Summary of Vehicle Counts Used to Calculate Public Doses

Direction of Vehicles $\quad \begin{aligned} & \text { Lanes of } \\ & \text { Traffic }\end{aligned} \quad \begin{aligned} & \text { Number of } \\ & \text { Vehicles }\end{aligned} \quad$ Public Exposed (a)

Traveling: (b)

Same direction Opposite direction Opposite direction

Parked: (c)

Same direction Opposite direction Opposite direction
2 or 4

2

4
113

168

1510
158

235

2114

100

150 
occupancy must be determined. For this report, it was assumed that the average occupancy was 1.4 persons per vehicle (Greenborg et a1. 1980).

The cumulative dose to the public traveling on a two-lane or four-lane highway was approximately 11.9 person-mrem (see Table 3.6). Approximately 1791 vehicles were involved with an average occupancy factor of 1.4 , or approximately 2507 individuals (see Appendix C for detailed calculations).

The cumulative dose to individuals parked at rest areas or weigh stations are also shown in Table 3.6. Approximately 666 individuals were exposed, receiving an accumulative dose of 0.02 person-mrem. Therefore, the total dose received by occupants of vehicles on the interstate at the time of the shipment was approximately 11.92 person-mrem.

Three population zones were identified for this analysis: rural, suburban, and urban. As discussed previously, these zones were identified based on an estimated population. Based on these populations, the following population densities were assigned to each zone:

$$
\begin{array}{ll}
\text { Rural } & 8.50 \mathrm{E}-06 \text { people } / \mathrm{m}^{2} \\
\text { Suburban } & 6.90 \mathrm{E}-05 \mathrm{people} / \mathrm{m}^{2} \\
\text { Urban } & 1.60 \mathrm{E}-03 \mathrm{people} / \mathrm{m}^{2}
\end{array}
$$

These zones are based on the route used for the shipment and have been derived from Rhoads et al. (1986).

Detailed dose calculations, using these population densities, are described in Appendix C. Based on Table 3.6 and the population densities encountered, the total dose to the general public for the entire shipment was 0.40 person-mrem.

\section{Calculated Occupational Doses}

Exposure data was not measured for the occupants of the tractor; therefore, occupational doses were calculated using the dose rate map shown in Figure 2.3. Occupational dose was calculated using a dose rate of $0.3 \mathrm{mrem} / \mathrm{hr}$ for the crew compartment and the time each individual was in the crew compartment. 
TABLE 3.6. In-Transit Dose Estimates for Shipment Number 20

\begin{tabular}{|c|c|c|c|c|}
\hline In-Transit Doses & $\begin{array}{l}\text { Lanes of } \\
\text { Iraffic }\end{array}$ & Vehicles & $\begin{array}{l}\text { Population } \\
\text { Densities } \\
\text { (people/m²) } \\
\end{array}$ & $\begin{array}{r}\text { Public Dose } \\
\text { (person-mrem) }\end{array}$ \\
\hline $\begin{array}{l}\text { Vehicles traveling in } \\
\text { in the same direction }\end{array}$ & 2 or 4 & 113 & & 11.30 \\
\hline $\begin{array}{l}\text { Vehicles traveling in } \\
\text { the opposing direction }\end{array}$ & 2 & 168 & & 0.33 \\
\hline $\begin{array}{l}\text { Vehicles traveling in } \\
\text { the opposing direction }\end{array}$ & 4 & 1510 & & 0.25 \\
\hline $\begin{array}{l}\text { Vehicles parked in } \\
\text { the same direction }\end{array}$ & 2 or 4 & 274 & & 0.02 \\
\hline \multirow{2}{*}{$\begin{array}{l}\text { Vehicles parked in } \\
\text { the opposing direction }\end{array}$} & 2 & 10 & & $3.0 E-04$ \\
\hline & 4 & 192 & & $4.1 E-03$ \\
\hline $\begin{array}{r}\text { General public: } \begin{array}{r}\text { Rural } \\
\text { Suburban } \\
\text { Urban }\end{array}\end{array}$ & & & $\begin{array}{l}8.50 \mathrm{E}-06 \\
6.90 \mathrm{E}-05 \\
1.60 \mathrm{E}-03\end{array}$ & $\begin{array}{l}0.07 \\
0.06 \\
0.27 \\
\end{array}$ \\
\hline \multicolumn{3}{|c|}{ Total Estimated Public Dose } & & 12.30 \\
\hline \multicolumn{3}{|c|}{$\begin{array}{r}\text { Occupational Dose: Driver } \\
\text { Second Person }\end{array}$} & & $\begin{array}{l}18.6 \\
17.3 \\
\end{array}$ \\
\hline \multicolumn{3}{|c|}{ Total Estimated In-Transit Dose } & & 48.2 \\
\hline
\end{tabular}

Regulations require that one individual remain with the shipment for the entire trip. For this shipment, the individual that remained with the shipment was either in the sleeper or in the passenger seat. It was assumed in this analysis that one person was in the crew compartment at all times and was exposed to the shipment for the maximum time period or 62 hours. The second person was responsible for filling the truck's fuel tanks and ordering meals. The total time the vehicle was stopped for refueling, "rest stops," and meals was 4.35 hours (see Table 3.7); therefore, the second individual was exposed to the shipment, in-transit, for 57.65 hours. The calculated intransit occupational doses for the person in the crew cab for the entire shipment and the second person were 18.6 person-mrem and 17.3 person-mrem, respectively. 


\section{TABLE 3.7. Calculated Doses for In-Transit Stops}

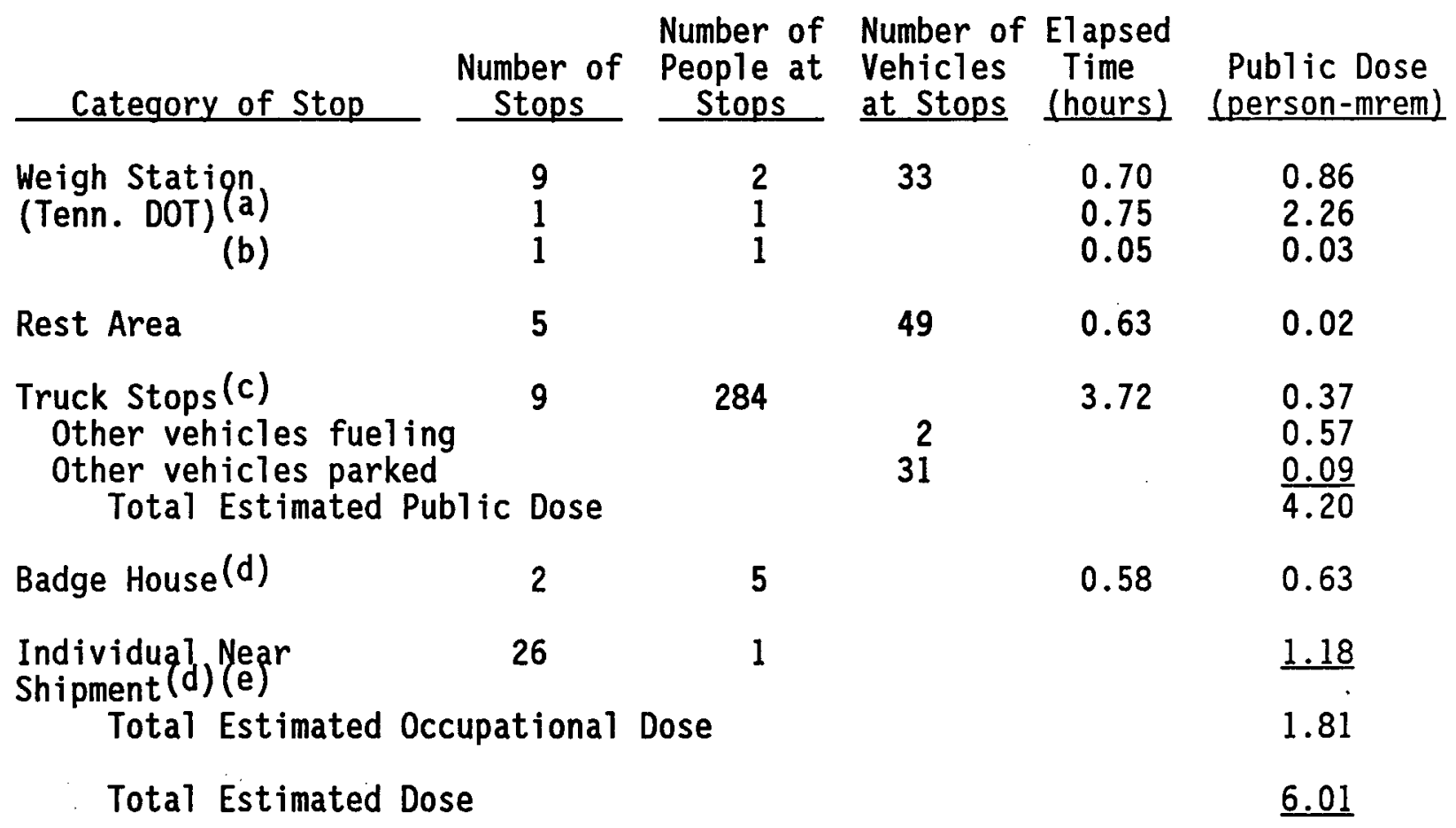

(a) One Tennessee DOT Inspector.

(b) One vehicle inspection.

(c) Includes one restaurant stop.

(d) Occupational doses.

(e) One person in the vicinity of the cask at all stops.

The total calculated in-transit dose to the public was 12.30 personmrem, and the total calculated occupational dose was 239.30 person-mrem. Therefore, the total in-transit dose was 251.60 person-mrem (see Table 3.6).

\subsubsection{Stops Dose Estimates}

Data were also collected each time the vehicle stopped at a weigh station, rest area, or truck stop (see Appendix B, Section B.4). The types of data collected included the reason for the stop, the date, the mileage, the time in and time out or the elapsed time, and general observations (for example, the number of vehicles or people in the immediate area.) This information was used to calculate public dose at each type or category of stop. 
Table 3.7 summarizes the data shown in Appendix B, Section B.4, and the calculated doses described in Appendix $C$.

The total dose to the public for all categories or types of stops was 4.20 person-mrem. The total occupational dose while the truck was stopped was 1.81 person-mrem; therefore, the total public and occupational dose was 6.01 person-mrem (see Table 3.7). The greatest portion of this dose was received by the State of Tennessee DOT Inspector and by one individual that was assumed to be in the vicinity of the shipment at each stop. The Tennessee DOT inspector was categorized as a member of the public, and the dose to this individual, who was in the vicinity of the shipment at each stop, was considered to be occupational dose.

\subsubsection{Summary of the Dose Estimates}

The total dose received due to shipping one TN-8L shipping cask was the sum of the dose estimates provided in Table 3.8, or 54.21 person-mrem. The total calculated occupational dose was 241.11 person-mrem. The total calcu7 ated public dose for the shipment was 16.50 person-mrem. This low dose to the public was the result of the limited number of in-transit stops and the average speed of the shipment, which reduced the number of hours the public was exposed to the shipment. 


\section{TABLE 3.8. Summary of Dose Estimates}

\begin{tabular}{|c|c|c|}
\hline Persons Exposed to Shipment & $\begin{array}{l}\text { People } \\
\text { Exposed }\end{array}$ & $\begin{array}{l}\text { Estimated Dose } \\
\text { (person-mrem) }\end{array}$ \\
\hline $\begin{array}{l}\text { Vehicles traveling in the } \\
\text { same direction }\end{array}$ & 158 & 11.30 \\
\hline $\begin{array}{l}\text { Vehicles traveling in the } \\
\text { opposite direction }\end{array}$ & 2349 & 0.58 \\
\hline $\begin{array}{l}\text { Vehicles parked in the } \\
\text { same direction }\end{array}$ & 384 & 0.02 \\
\hline $\begin{array}{l}\text { Vehicles parked in the } \\
\text { opposite direction }\end{array}$ & 283 & $4.4 \mathrm{E}-03$ \\
\hline Rural population zone & $8.50 \mathrm{E}-06 / \mathrm{m}^{2}$ & 0.07 \\
\hline Suburban population zone & $6.90 \mathrm{E}-05 / \mathrm{m}^{2}$ & 0.06 \\
\hline Urban population zone & $1.60 \mathrm{E}-03 / \mathrm{m}^{2}$ & 0.27 \\
\hline Weigh stations & 50 & 3.15 \\
\hline Rest areas & 69 & 0.02 \\
\hline Truck stops & 356 & 2.21 \\
\hline Badge house & 5 & 0.63 \\
\hline Drivers & 2 & 35.9 \\
\hline \multicolumn{2}{|c|}{ Total Calculated Dose } & 54.21 \\
\hline
\end{tabular}




\subsection{DRY CASK UNLOADING}

Handling times and personnel exposure resulting from unloading the TN-8L shipping cask at the TAN facility at INEL were obtained by PNL personnel. Unloading operations, handling times, and personnel requirements are presented in Section 4.1. Calculated occupational doses resulting from dry cask unloading operations are presented in Section 4.2. These doses were calculated based on actual time/motion data and exposure data collected by PNL personnel.

\subsection{DRY CASK HANDLING}

Dry spent fuel assembly transfer from the TN-8L shipping cask to the Westinghouse MC-10 spent fuel storage cask (capacity $=24$ PWR spent fuel assemblies) are covered by detailed operating procedures entitled "TAN SFSC Program Fuel Receipt and Transfer from TN-8L Shipping Cask to MC-10 Storage Cask."

The INEL TAN-607 warm and hot shops are described in Section 4.1.1. Cask-handling operations are summarized in Section 4.1.2, and staff requirements are outlined in Section 4.1.3. Cask-handling times are discussed in Section 4.1 .4 .

\subsubsection{TAN-607 Warm and Hot Shops}

A top view of the TAN-607 warm and hot shops cask-handling facility is shown in Figure 4.1. The truck arrives and is backed into the warm shop

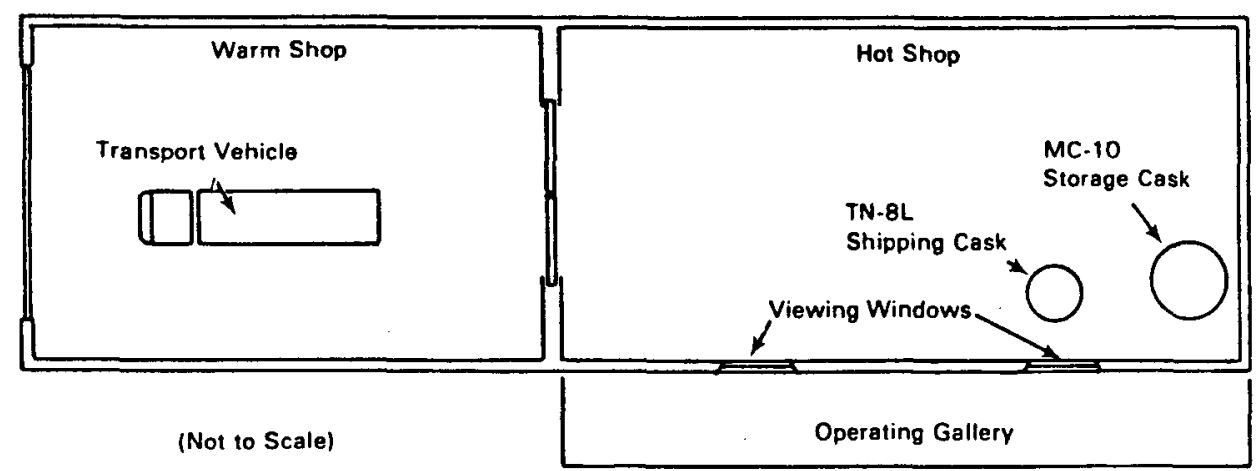

FIGURE 4.1. Top View of the TAN-607 Warm and Hot Shops Cask-Handling Facility 
area, as shown by Figure 4.2. Following retraction of the personnel barrier and monitoring activities, the trailer is backed in the hot shop area. A diagram of hot shop shipping cask removal from the transport vehicle is shown in Figure 4.3. The upended shipping cask is then placed adjacent to the

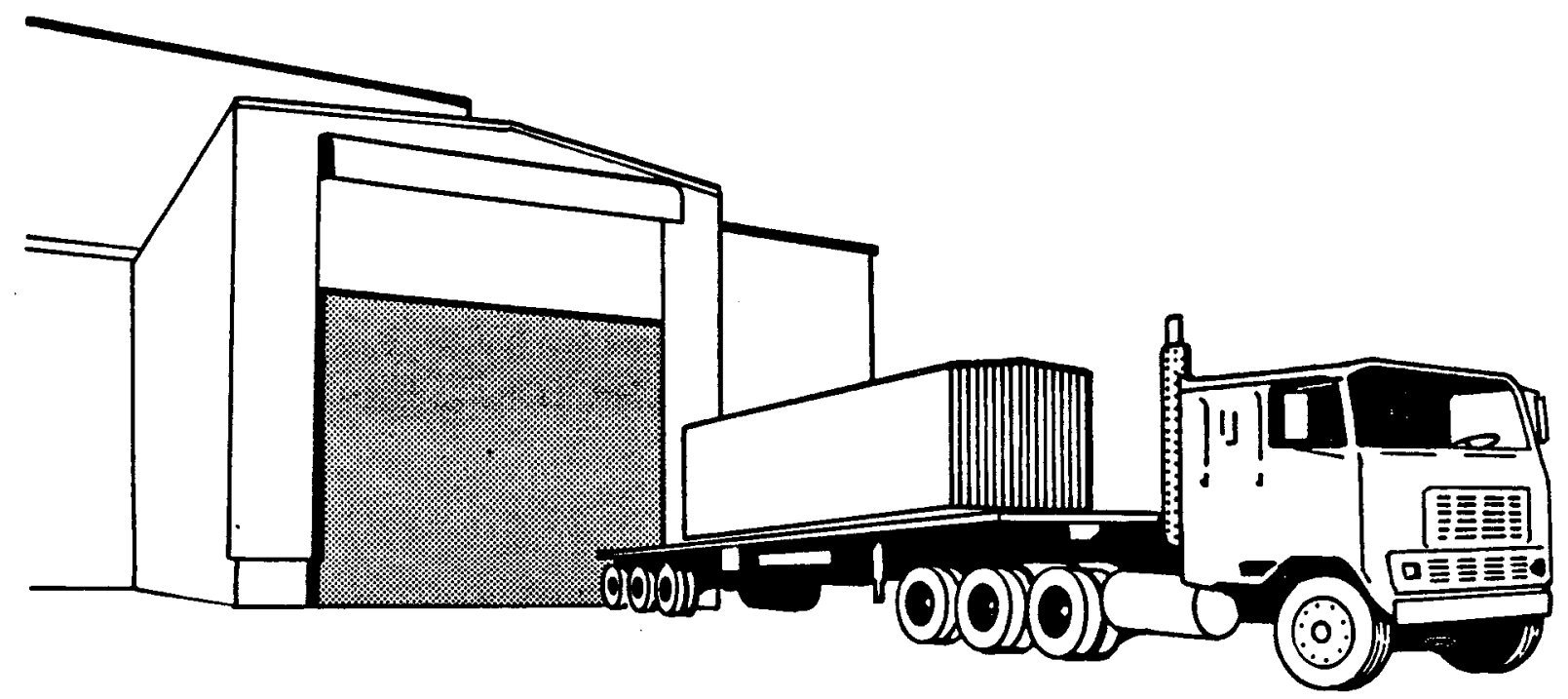

FIGURE 4.2. Truck Backing into Warm Shop Area

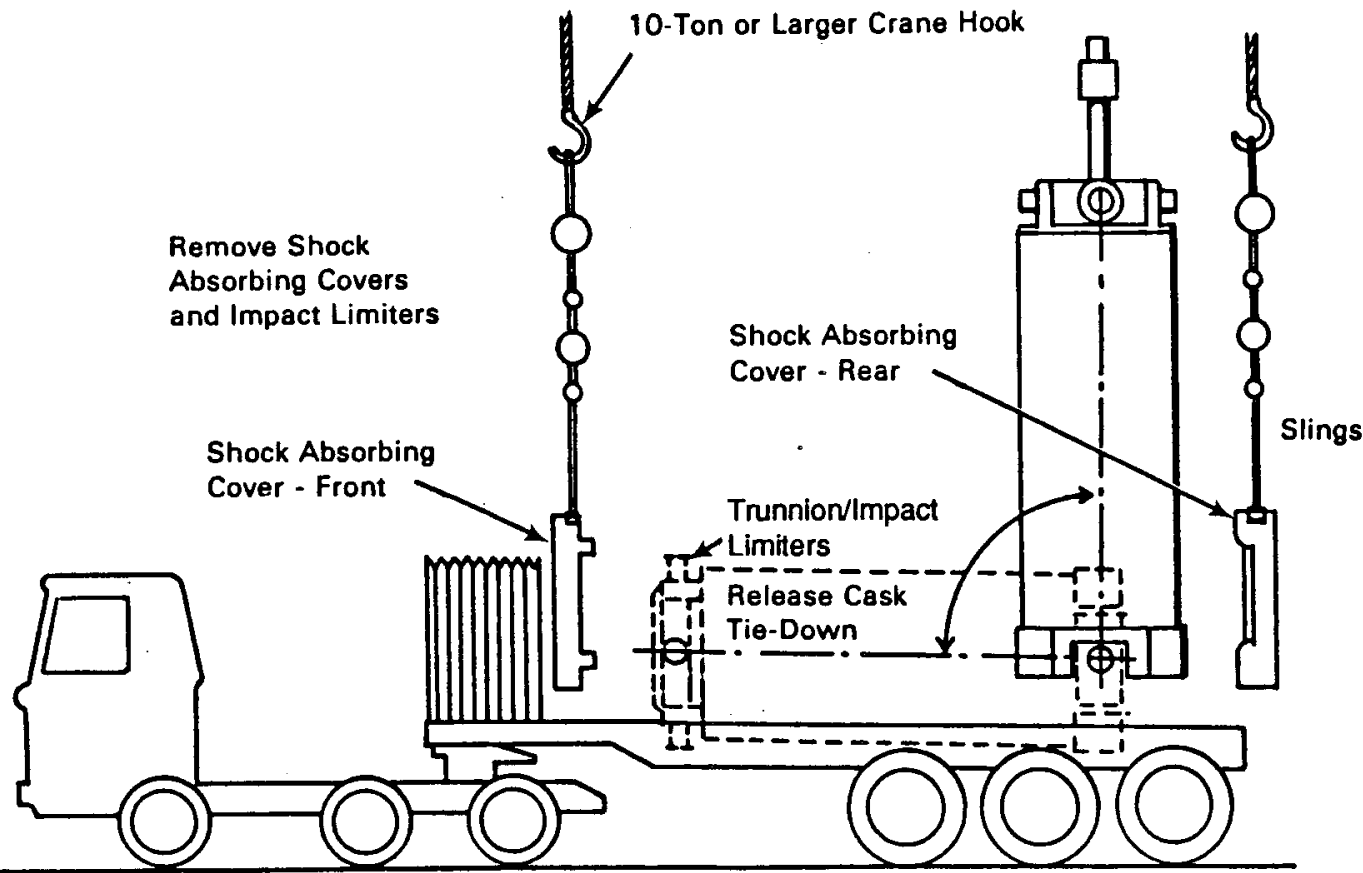

FIGURE 4.3. Hot Shop Shipping Cask Removal from the Transport Vehicle 
MC-10 Storage Cask (shown in Figure 4.4) in preparation for fuel transfer. The removable portion of the work platform (Figure 4.5 ) is then installed to complete the hot shop dual cask workstand, which is shown in Figure 4.6.

All operations are manually performed by operators in the hot shop, with the exception of fuel transfer, which is remotely performed.

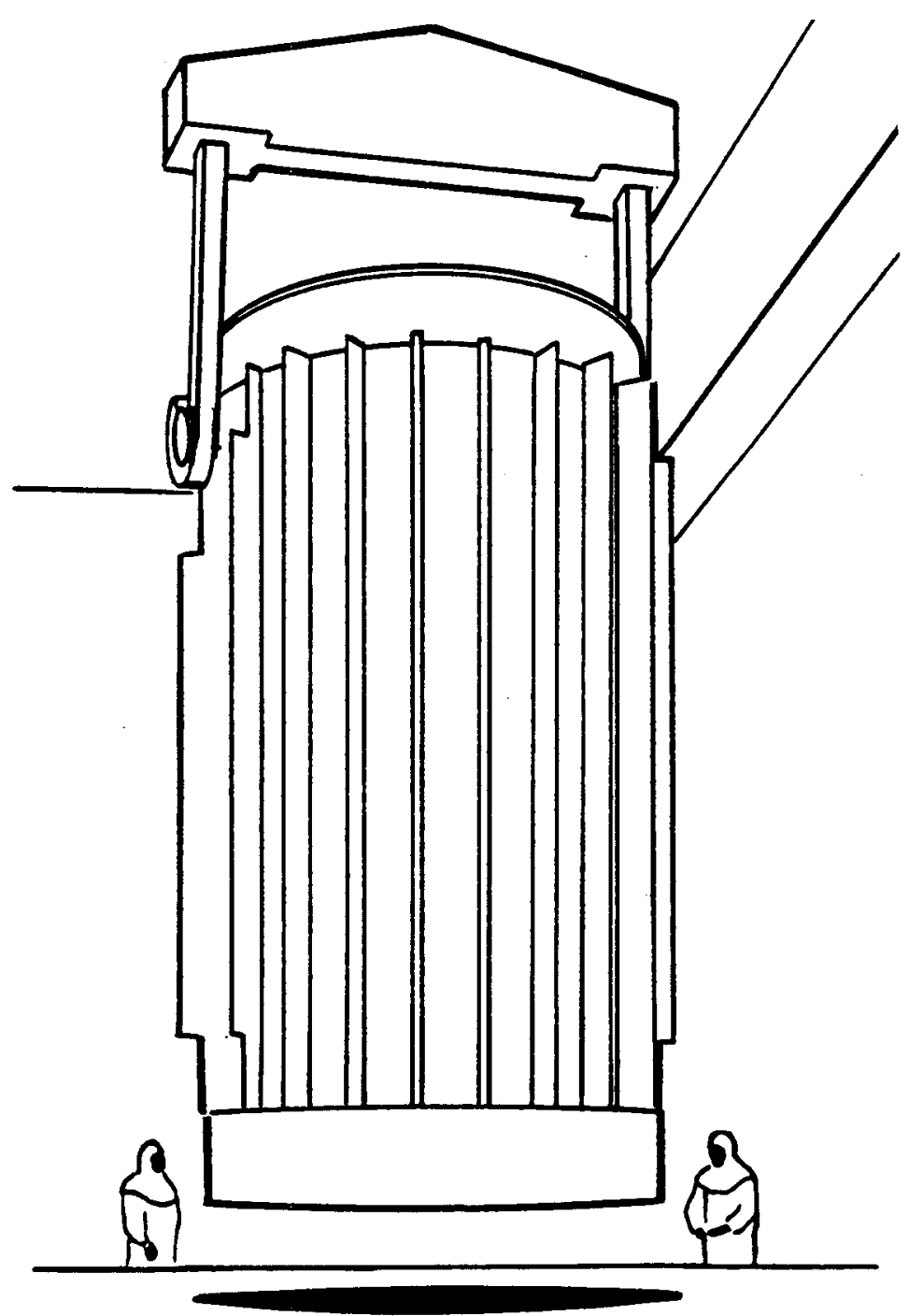

FIGURE 4.4. MC-10 Storage Cask 


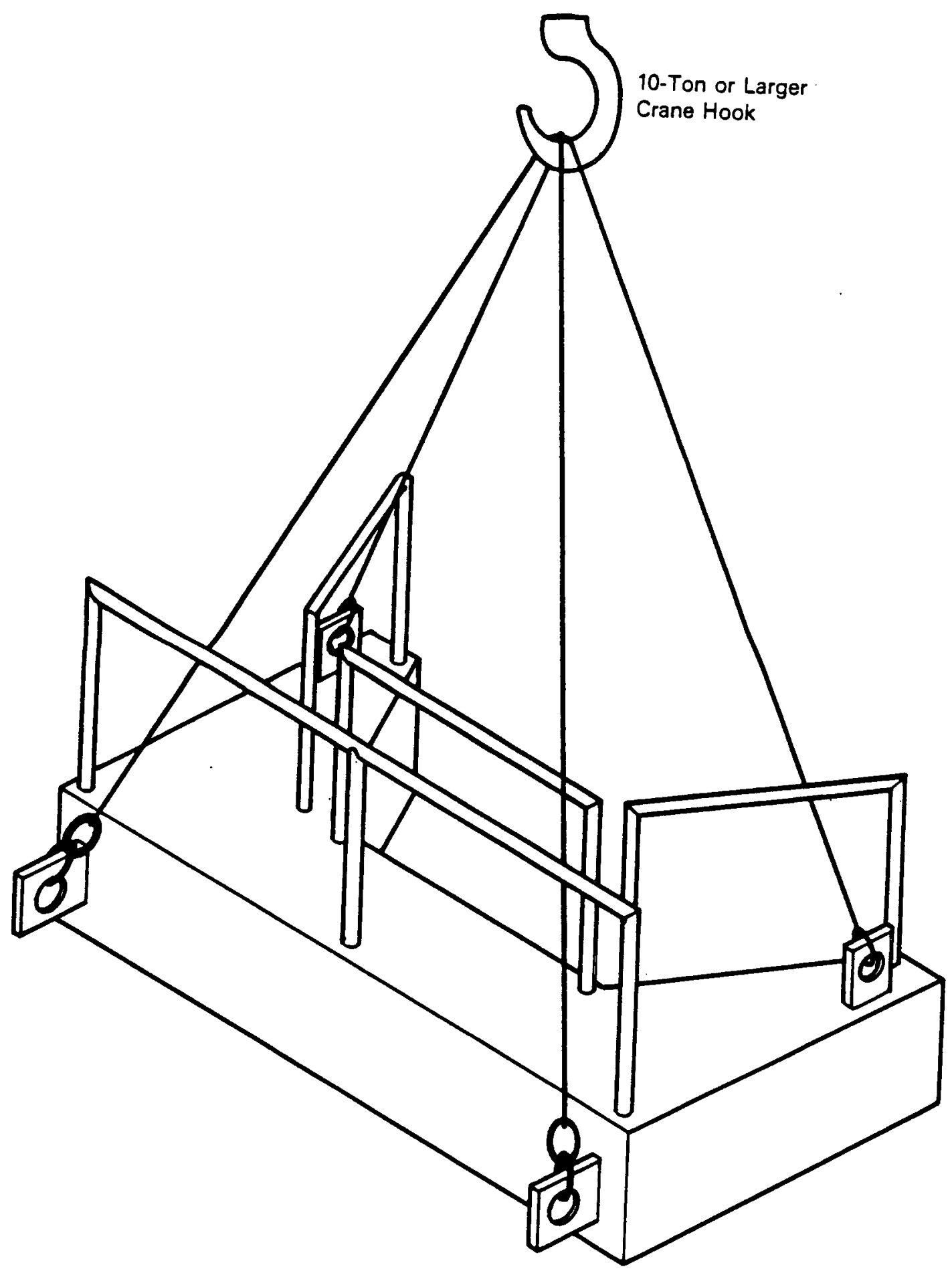

FIGURE 4.5. The Removable Portion of the Work Platform

4.4 
in

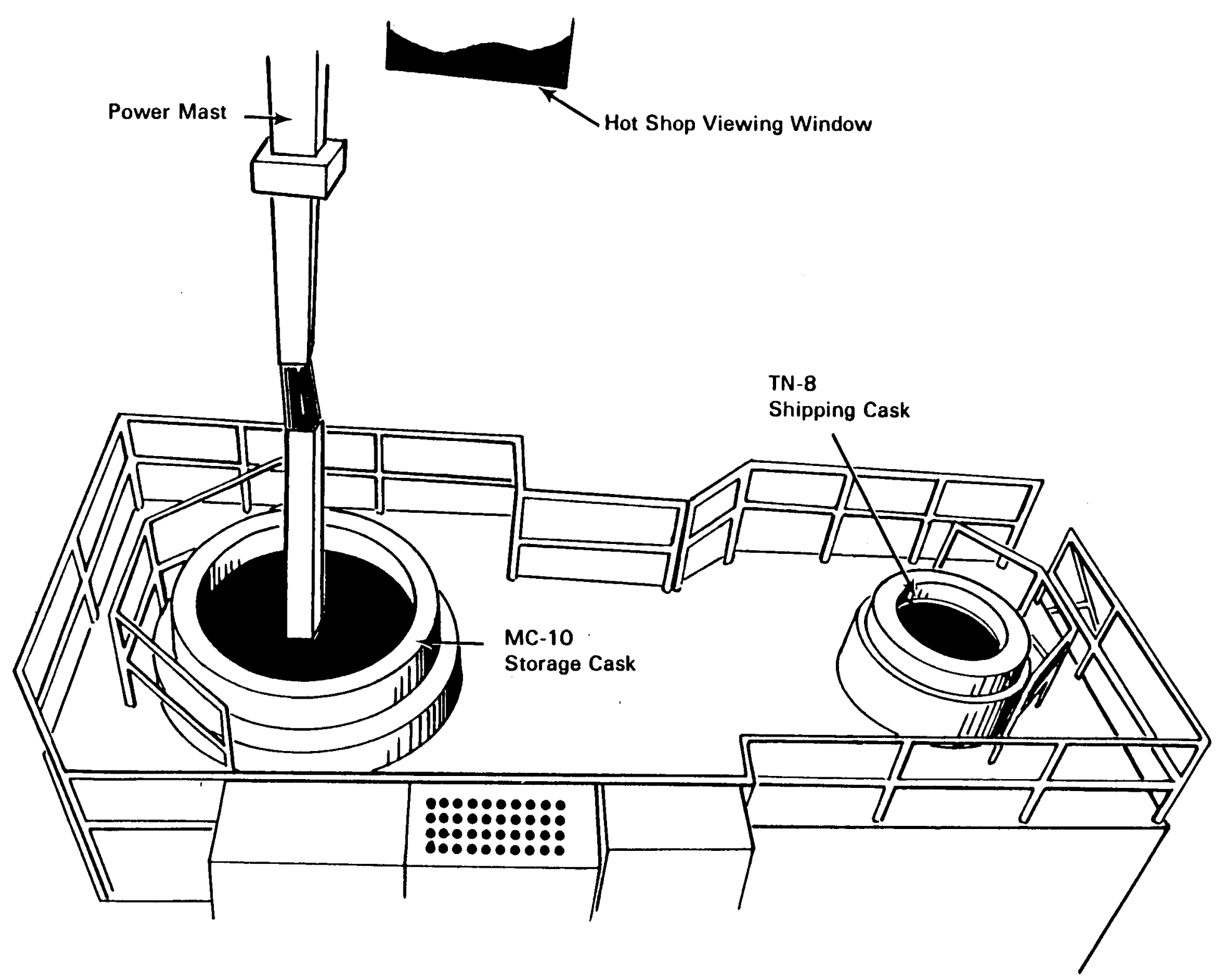

FIGURE 4.6. Hot Shop Dual Cask Workstand 


\subsubsection{Cask Handling Operations}

Detailed cask handling activities for hot cell cask unloading are described in Appendix D. Major cask handling steps are described below:

1. Receive TN-8L cask.

2. Prepare for unloading the $\mathrm{TN}-8 \mathrm{~L}$ cask.

3. Prepare the TN-8L cask for fuel transfer.

4. Prepare the MC-10 for fuel transfer.

5. Prepare the TN-8L cask lid for removal.

6. Prepare and verify for remote fuel transfer.

7. Remove TN-8L and MC-10 cask lids and remotely inspect MC-10 lid 0-rings.

8. Transfer fuel.

9. Video tape MC-10 basket fuel compartment.

10. Replace MC-10 storage-cask 1 id.

11. Secure MC-10 storage-cask test 7 id: perform interim tests or cask tests.

12. Evacuate the MC-10 storage cask and backfill with nitrogen for interim fuel storage, or with helium for testing.

13. Take TN-8L shipping-cask internal smear samples and replace cask 1 id.

14. Prepare the TN-8L cask for loading onto the shipping trailer.

15. Load the TN-8L shipping cask onto the trailer.

16. Prepare TN-8L shipping cask for return shipment.

\section{Activity 1 - Receive TN-8L Cask}

After the Toaded shipping cask arrives at the TAN-601 guard station, papers are checked and the shipment is escorted to the warm shop area shown in Figure 4.1. The tarpaul in personnel barrier is retracted and a radiation survey is performed. A vehicle washdown can be performed in the warm shop if required. 


\section{Activity 2 - Prepare for Unloading the TN-8L Cask}

Plastic is placed down on the hot shop floor, the hot shop door is opened, and the trailer is backed into the hot shop area. Trunnion and cask impact limiters are then removed. The front tiedown, the trunnion guide assembly, and the rear tiedown are then removed. Lifting trunnions are lubricated, and the cask is upended and transferred to the shipping cask work platform. The removal portion of the work platform is then installed. The transport vehicle leaves the hot shop, and the hot shop doors are closed.

\section{Activity 3 - Prepare the TN-8L Cask for Fuel Transfer}

Contamination control plastic is placed over the edge of the cask top and around the work platform. A sample cylinder is attached to the gas testing port, and a gas sample and pressure test are taken. If radioactivity is detected in the gas sample, the cask is evacuated before the lid is removed. Activity 4 - Prepare the MC-10 for Fuel Transfer

The MC-10 storage cask 1 id is surveyed, and the lid bolts are removed. The lid lifting adapter is then attached to the storage cask $1 \mathrm{id}$.

\section{Activity 5 - Prepare the TN-8L Cask Lid for Removal}

Cask lid bolts are removed and inspected, the lid lifting adapter is then installed for lid removal, and the hot shop 10-ton crane is attached. Activity 6 - Prepare and Verify for Remote Fuel Transfer

A11 equipment is checked and additional contamination control plastic is installed. All personnel leave the hot shop area in preparation for remote operations.

Activity 7 - Remove TN-8L and MC-10 Cask Lids and Remotely Inspect MC-10 Lid O-Rings

With the 10-ton hot shop crane, the TN-8L cask 1 id is removed and placed on the cask 1id support stand. Using a wall mounted power mast, the cask front face metal protective cover is placed on top of the TN-8L shipping cask. The 100-ton crane is then used to 1 ift the MC-10 cask lid for remote 
lid 0 -ring inspection. Following 0 -ring inspection, the 1 id is placed on a support stand. The wall-mounted power mast is then used to install the MC-10 surface protector plate.

\section{Activity 8 - Fuel Transfer}

The 10-ton crane is remotely connected to the Westinghouse fuel grapple. The crane then moves the grapple to the TN-8L shipping cask where the grapple is engaged to the first spent fuel assembly to be moved. The spent fuel assembly is then placed into the MC-10 storage cask. This process is repeated for three spent fuel assemblies.

\section{Activity 9 - Video Tape MC-10 Basket Fuel Compartment}

The MC-10 basket assembly is video taped to verify basket integrity from one unloading to the next.

\section{Activity 10 - Replace MC-10 Storage-Cask Lid}

Using the wall-mounted power mast, the $M C-10$ surface protector plate is removed. The 100-ton hot cell crane then replaces the MC-10 storage cask 1id. If radiation levels of airborne particulates are acceptable, personnel enter the hot shop and obtain smear surveys. Contamination control plastic is removed, and the MC-10 lifting lid adapter is unbolted and removed.

Activity 11 - Secure MC-10 Storage-Cask Test Lid: Interim or Cask Testing

Following the torque sequences, MC-10 lid bolts are installed.

Activity 12 - Evacuate the MC-10 Storage Cask and Backfill Nitrogen for Interim Fuel Storage or with Helium for Testing

In parallel with other activities, the MC-10 storage cask is evacuated and backfilled with nitrogen.

Activity 13 - Take TN-8L Shipping-Cask Internal Smear Samples and Replace Cask Lid

Smear samples are taken and the metal front face cover protector removed using the wall-mounted power mast. The 1id is then installed with the 10-ton hot shop crane, and the lid lifting adapter is removed. Following the torque sequence, lid bolts are installed. 


\section{Activity 14 - Prepare the TN-8L Cask for Loading onto Shipping Trailer}

All flanges are replaced, and the cask is surveyed for radiation and decontaminated as required.

\section{Activity 15 - Load the TN-8L Shipping Cask onto Trailer}

With the 10-ton hot shop crane, the removable portion of the work platform is removed. The truck and trailer are backed into the hot shop area. The TN-8L cask is then lifted by the 100-ton crane and lowered onto the transport trailer. Front and rear tiedowns are then installed.

Activity 16 - Prepare TN-8L Shipping Cask for Return Shipment

The cask ends are surveyed and decontaminated as required. The impact limiters are installed on the trunnions and on the cask ends. A contamination survey is then completed on the trailer, and the trailer is decontaminated as required. The truck then moves into the warm shop area, and security seals on the front and rear impact limiters are installed. The personnel barrier protective enclosure is then installed, and a final contamination survey is performed. The paperwork is completed, and the transport vehicle and cask are released.

\subsubsection{Cask-Handling Staffing Requirements at the TAN Facility}

The observed cask unloading at the TAN facility was performed by one shift that was held over until unloading operations were completed. Although many individuals were observed participating in cask-handling activities, a core group of five individuals (excluding truck drivers) were needed to complete cask-handling activities. This essential core group consisted of one health physics individual and four operators/technicians.

\subsubsection{TAN Facility Cask-Handling Times}

The handling time for each major step is shown in Table 4.1. The total handling time of $8.2 \mathrm{hrs}$ is the actual handling time and is not the cask turnaround time at the TAN facility. Actual cask turnaround time was approximately 16 hours. Delays that were encountered included a lunch break, a brief power failure, a staff meeting, and a load cell indicator failure for the 10-ton hot shop crane. The load cell indicator failure occurred during 
TABLE 4.1. TAN Facility Shipping-Cask Handling Times Activity

1. Receive TN-8L cask. Elapsed Time (minutes)

2. Prepare for unloading $T N-8 L$ cask. 39

3. Prepare the TN-8L cask for fuel transfer. 74

4. Prepare the MC-10 for fuel transfer. 29

5. Prepare the TN-8L cask lid for removal. Parallel Activity

6. Prepare and verify for remote fuel transfer. 12

7. Remove $T N-8 L$ and $M C-10$ casks remote $7 i d$. 28

8. Transfer fuel. 56

9. Video tape MC-10 basket fuel compartment. 33

10. Replace MC-10 storage cask 1 id. Not Observed

11. Secure MC-10 storage cask test 1id: interim or for cask testing.

12. Evacuate the MC-10 storage cask and backfill with nitrogen for interim fuel storage or with helium for testing.

13. Take TN-8L shipping cask smear samples and replace Tid.

14. Prepare the TN-8L cask for loading onto shipping trailer.

34

Not Observed Parallel Activity

15. Load the TN-8L shipping cask onto trailer.

16. Prepare TN-8L shipping cask for return shipment. 78 493 ( 8.2 hours)

the lifting of the first spent fuel assembly. The weight of the spent fuel assembly did not register on the load cell indicator in the operating gallery servicing the hot shop. After a technician arrived, the problem was corrected by resetting the digital display, which had not been functioning properly since a brief power failure earlier in the day. 
The TAN facility crew was extremely well organized and completed activities in parallel whenever possible. From observing the TAN facility crew, it is apparent that even when using manual cask-handling techniques (i.e., hand wrenches, etc.), a repository cask handling crew could achieve truck cask turnaround times of less than 10 hours, as unnecessary delays (i.e., staff meeting) could be eliminated.

\subsection{IAN FACILITY CASK DOSE EVALUATION}

Dose evaluation for the TAN facility TN-8L cask unloading was based on observed handling times and the cask dose rate map prepared by Virginia Power (Figure 2.3). General area dose rates were estimates obtained from application of health physics principles, and were assumed to be $0.2 \mathrm{mrem} / \mathrm{hr}$ for the warm shop, and $2 \mathrm{mrem} / \mathrm{hr}-10 \mathrm{mrem} / \mathrm{hr}$ for the hot shop. Due to the lack of information, the general area dose rate for the operating gallery was assumed to be zero.

The dose analysis for cask unloading is presented in Appendix $D$ and is summarized by major activities in Table 4.2. Major activities that were not observed were not included in the dose analysis. As shown in Table 4.3, the estimated total dose for $\mathrm{TN}-8 \mathrm{~L}$ unloading operations is 130.9 person-mrem. Approximately $96 \%$ of total dose is due to background or general area dose, and only $4 \%$ of total dose is received from the shipping cask. The highest dose producing activity is Activity 13 , which involves taking TN-8L shipping cask smear samples and replacing the lid. 
TABLE 4.2. TAN Facility Personnel Dose due to Unloading Activities

Calculated
Doses

Doses (person-mrem)

Cask Back-

Activity

Work ground Total

1. Receive TN-8L cask.

$\begin{array}{lll}0.6 & 0.7 & 1.3\end{array}$

2. Prepare for unloading TN-8L cask.

$1.3 \quad 10.8 \quad 12.1$

3. Prepare the TN-8L cask for fuel transfer.

$\begin{array}{lll}1.7 & 24.2 & 25.9\end{array}$

4. Prepare the MC-10 for fuel transfer.

Not observed

5. Prepare the TN-8L cask lid for removal.

0.7

6.0

6.7

6. Prepare and verify for remote fuel transfer.

1.0

14

15

7. Remove $\mathrm{TN}-8 \mathrm{~L}$ and $\mathrm{MC}-10$ casks remote lid.

0.0

0.0

0.0

8. Transfer fuel.

0.0

0.0

0.0

9. Video tape MC-10 basket fuel compartment.

Not Observed

10. Replace MC-10 storage cask lid.

0.0

0.0

0.0

11. Secure MC-10 storage cask test lid.

Not Observed

Not Observed

12. Evacuate the MC-10 cask.

$\begin{array}{lll}0.0 & 49.2 \quad 49.2\end{array}$

13. Take TN-8L shipping cask smear samples and replace lid.

14. Prepare the cask for loading onto trailer.

0.0

8.3

8.3

15. Load cask onto trailer.

0.0

8.8

8.8

16. Prepare $\mathrm{TN}-8 \mathrm{~L}$ shipping cask for return shipment.

$\begin{array}{lrr}\frac{0.0}{5.3} & \underline{3.6} & \frac{3.6}{125.6}\end{array}$




\subsection{REFERENCES}

Greenborg, J. 1980. Application of ALARA Principles to Shipment of Spent Fuel. PNL-3261, Pacific Northwest Laboratory, Richland, Washington.

Knox, et a1. 1986. Transportation of Radioactive Materials: A Summary of State and Local Legis lative Requirements for the Period Ending December 31 , 1985. ORNL/TM-9985, Oak Ridge National Laboratory, Oak Ridge, Tennessee.

Rhoads, R. E., A. L. Franklin, and J. C. Lavender. 1986. Evaluation of Methods to Compare Consequences from Hazardous Materials Transportation Accidents. SAND86-7117, Sandia National Laboratories, Albuquerque, New Mexico.

U.S. Department of Energy (DOE). 1987. Analysis of Radiation Doses from Operation of Postulated Commercial Spent Fuel Transport Systems.

DOE-CH/TP0-001, U.S. Department of Energy, Chicago Operations Office, Argonne, I1linois. 


\section{APPENDIX A}

TN-8L CASK HANDLING--REACTOR LOADING 
TABLE A.1. TN-8L Cask Handling--Time and Motion Form

\begin{tabular}{|c|c|c|c|c|c|c|c|c|c|c|}
\hline Activity & Area & $\begin{array}{l}\text { Crew } \\
\text { Members } \\
\text { Required }\end{array}$ & $\begin{array}{l}\text { Support } \\
\text { Members } \\
\text { in Area }\end{array}$ & $\begin{array}{l}\text { Time } \\
\text { in } \\
\text { Area } \\
\text { (min) }\end{array}$ & $\begin{array}{c}\text { Average } \\
\text { Distance } \\
\text { from } \\
\text { Cask } \\
(f t) \\
\end{array}$ & $\begin{array}{l}\text { Dose } \\
\text { Rate } \\
\text { from } \\
\text { Cask } \\
(\mathrm{mR} / \mathrm{Hr}) \\
\end{array}$ & $\begin{array}{l}\text { General } \\
\text { Area } \\
\text { Dose } \\
\text { Rate } \\
(\mathrm{mR} / \mathrm{Hr})\end{array}$ & $\begin{array}{l}\text { Cumulative } \\
\text { Clock Time } \\
\text { (min) } \\
\end{array}$ & $\begin{array}{l}\text { Cumulative } \\
\text { Dose } \\
\text { from Cask } \\
\text { (mR) } \\
\end{array}$ & $\begin{array}{l}\text { Uumulative } \\
\text { General } \\
\text { Area } \\
\text { Dose } \\
(\mathrm{mR}) \\
\end{array}$ \\
\hline A. Unloading & & & & & & & & & & \\
\hline 1. HP survey for cask contamination & Yard & 2 & 0 & 45 & 3 & 0.00 & 0.00 & 45 & 0.00 & 0.00 \\
\hline 2. QC inspection of trailer & Yard & 1 & 0 & 10 & 5 & 0.00 & 0.00 & 45 & 0.00 & 0.00 \\
\hline 3. Sign bill of lading & Yard & 1 & 0 & 22 & 25 & 0.00 & 0.00 & 47 & 0.00 & 0.00 \\
\hline 4. Tractor leaves trailer and cask & Yard & 2 & 0 & 10 & 10 & 0.00 & 0.00 & 57 & 0.00 & 0.00 \\
\hline 5. Yard tractor attaches to trailer & Yard & 2 & 0 & 5 & 10 & 0.00 & 0.00 & 62 & 0.00 & 0.00 \\
\hline 6. Security search & Yard & 3 & 0 & 15 & 10 & 0.00 & 0.00 & 77 & 0.00 & 0.00 \\
\hline 7. Enter gate; move to $\mathrm{C} / \mathrm{E}$ & Yard & 1 & 0 & 15 & 15 & 0.00 & 0.00 & 92 & 0.00 & 0.00 \\
\hline 8. Roll back protective cover & C/E & 4 & 2 & 5 & 4 & 0.00 & 0.25 & 97 & 0.00 & 0.13 \\
\hline 9. Remove trunnion impact limiters & C/E & 1 & 0 & 5 & 1 & 0.00 & 0.25 & 102 & 0.00 & 0.15 \\
\hline 10. Remove shock absorbing covers & C/E & 3 & 0 & 20 & 2 & 0.00 & 0.25 & 117 & 0.00 & 0.40 \\
\hline 11. Remove front tie-down binders & C/E & 1 & 0 & 5 & 1 & 0.00 & 0.25 & 122 & 0.00 & 0.42 \\
\hline 12. Remove trunnion guide assembly & C/E & 1 & 0 & 5 & 1 & 0.00 & 0.25 & 122 & 0.00 & 0.44 \\
\hline 13. Remove rear tie-down collars & $C / E$ & 1 & 0 & 5 & 1 & 0.00 & 0.25 & 122 & 0.00 & 0.46 \\
\hline 14. Attach horizontal lift beam to cask & C/E & 5 & 1 & 10 & 5 & 0.00 & 0.25 & 132 & 0.00 & 0.71 \\
\hline 15. Lift cask, move to tilting frame & C/E & 3 & 3 & 5 & 10 & 0.00 & 0.25 & 137 & 0.00 & 0.83 \\
\hline 16. Unhook horizontal lift beam, store & $\mathrm{C} / \mathrm{E}$ & 5 & 1 & 5 & 10 & 0.00 & 0.25 & 142 & 0.00 & 0.96 \\
\hline 17. At tach lift beam to cask & C/E & 5 & 1 & 10 & 10 & 0.00 & 0.25 & 152 & 0.00 & 1.21 \\
\hline 18. Tilt cask to vertical & C/E & 3 & 0 & 5 & 25 & 0.00 & 0.25 & 157 & 0.00 & 1.27 \\
\hline 19. Move cask to decon building & C/E & 1 & 2 & 10 & 15 & 0.00 & 0.25 & 167 & 0.00 & 1.40 \\
\hline 20. Attach bottom cover & D/B & 2 & 1 & 2 & 1 & 0.00 & 2.00 & 169 & 0.00 & 1.60 \\
\hline 21. Unhook lift beam, attach lid lift system & D/B & 2 & 1 & 3 & 25 & 0.00 & 0.25 & 172 & 0.00 & 1.63 \\
\hline B. Preparation for Loading & & & & & & & & & & \\
\hline 1. Tape over holes, rough surfaces & $0 / B$ & 3 & 0 & 15 & 1 & 0.00 & 2.00 & 15 & 0.00 & 1.50 \\
\hline 2. Attach protective skirt & $0 / \mathrm{B}$ & 3 & 0 & 30 & 1 & 0.00 & 3.00 & 45 & 0.00 & 6.00 \\
\hline 3. Tape over skirt joints & $0 / B$ & 3 & 0 & 10 & 1 & 0.00 & 3.00 & 55 & 0.00 & 7.50 \\
\hline 4. Attach "J" connectors & $0 / B$ & 2 & 0 & 10 & 1 & 0.00 & 3.00 & 65 & 0.00 & 8.50 \\
\hline 5. Vent cask cavity to atmospheric pressure & D/B & 1 & 0 & 15. & 2 & 0.00 & 2.00 & 70 & 0.00 & 9.00 \\
\hline 6. Remove "A", "C" ports flanges & D/B & 1 & 0 & 10 & 1 & 0.00 & 3.00 & 80 & 0.00 & 9.50 \\
\hline
\end{tabular}


TABLE A.1. (contd)

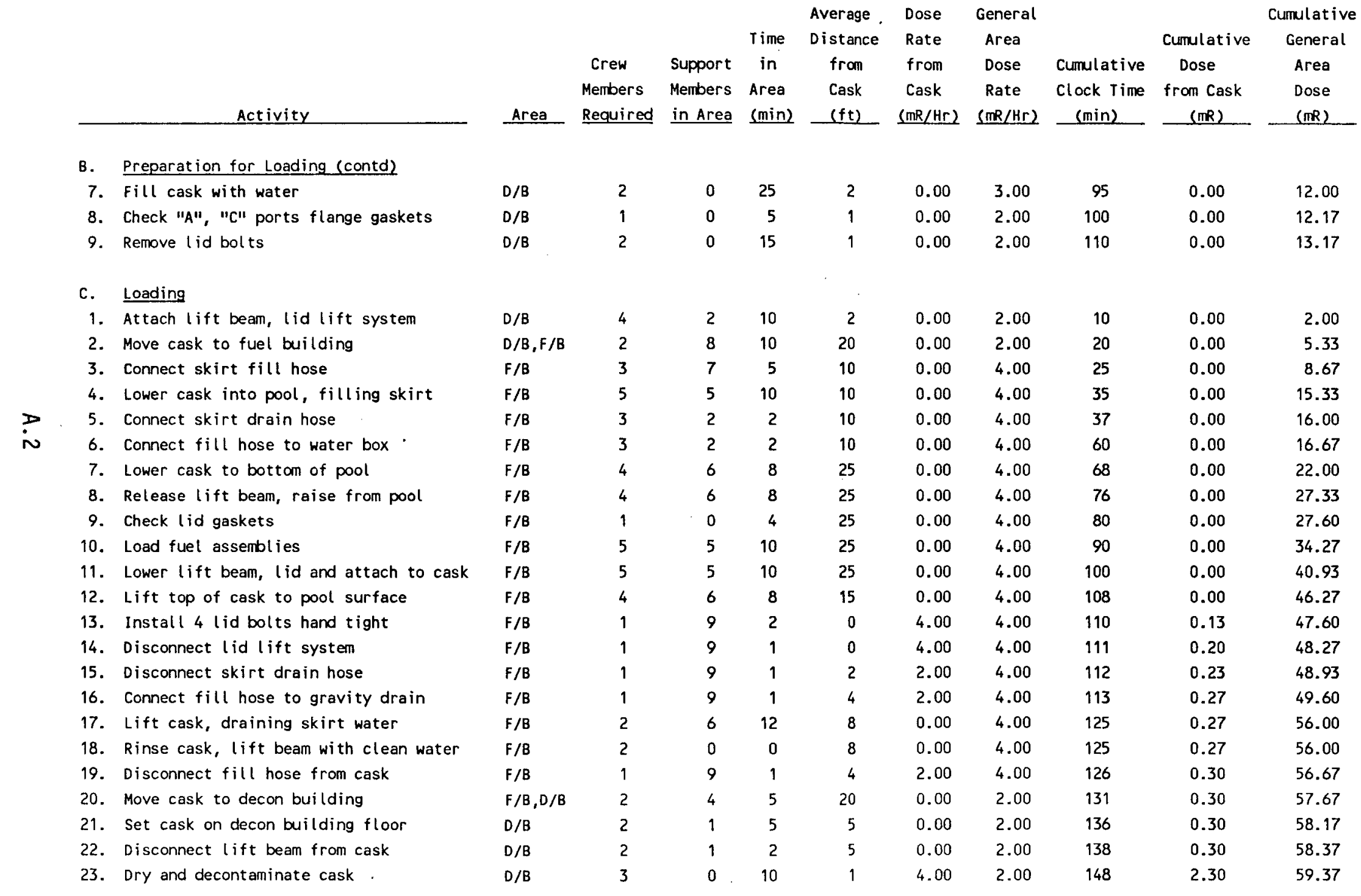


IABLE A.1. (contd)

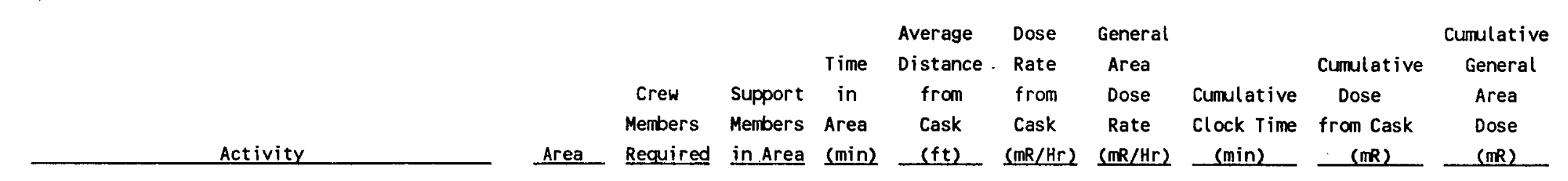

D. Testing for Departure

1. Install and torque lid bolts

2. Install thermocouples

3. Test lid tightness

4. Drain cavity water to floor drain

$D / B$

5. Blow-down cavity of residual water

6. Test cavity dryness

7. Test flange "A" for tightness

8. Backfill cavity with nitrogen

\section{$D / B$}

$D / B$

$D / B$

$D / B$

$D / B$

$D / B$

9. Check external contamination, remove tape $D / B$

10. Test flanges "B", "C", "D" for tightness $D / B$

$\omega$ 11. Remove "J" connectors, install flanges $D / B$

12. Remove protective skirt

13. Check fins for contamination

$D / B$

E. Preparation for Departure

1. Engage lift beam, lift 1 foot

2. Remove botton cover, decon

3. Move cask to tilting frame

4. Lubricate rear trunnion supports

5. Lower cask to tilting frame

6. Disengage lift beam, store

7. Check contamination, dose rates

8. Move trailer to center of C/E

9. Engage horizontal lift beam

10. Attach horizontal lift beam to cask

11. Raise cask above protective cover

12. Lower cask onto trailer

13. Disengage horizontal lift beam, store

14. Install rear tie-down binders

D/B
$D / B$
$C / E$
$C / E$
$C / E$
$C / E$
$C / E$
$C / E$
$C / E$
$C / E$
$C / E$
$C / E$
$C / E$
$C / E$

$\begin{array}{rrrrr}4.00 & 2.00 & 15 & 2.00 & 1.00 \\ 4.00 & 2.00 & 20 & 2.33 & 1.17 \\ 4.00 & 2.00 & 35 & 3.67 & 1.83 \\ 3.00 & 3.00 & 50 & 5.17 & 3.33 \\ 3.00 & 3.00 & 65 & 6.67 & 4.83 \\ 3.00 & 2.00 & 95 & .9 .67 & 6.83 \\ 4.00 & 2.00 & 15 & 12.33 & 8.17 \\ 2.00 & 2.00 & 125 & 13.00 & 8.83 \\ 4.00 & 3.00 & 140 & 16.00 & 11.08 \\ 4.00 & 3.00 & 180 & 21.33 & 15.08 \\ 4.00 & 3.00 & 185 & 21.67 & 15.33 \\ 3.00 & 3.00 & 205 & 24.67 & 18.33 \\ 3.00 & 2.00 & 215 & 25.17 & 18.67\end{array}$

$\begin{array}{lllll}0.00 & 3.00 & 15 & 0.00 & 1.50 \\ 3.00 & 2.00 & 30 & 1.50 & 2.50 \\ 0.00 & 0.25 & 40 & 1.50 & 2.75 \\ 0.00 & 0.25 & 42 & 1.50 & 2.80 \\ 0.00 & 0.25 & 47 & 1.50 & 2.93 \\ 0.00 & 0.25 & 52 & 1.50 & 3.05 \\ 2.00 & 0.25 & 67 & 3.50 & 3.68 \\ 0.00 & 0.25 & 69 & 3.50 & 3.68 \\ 0.00 & 0.25 & 77 & 3.50 & 3.93 \\ 2.00 & 0.25 & 74 & 4.33 & 4.06 \\ 0.00 & 0.25 & 82 & 4.33 & 4.18 \\ 2.00 & 0.25 & 87 & 5.17 & 4.31 \\ 0.00 & 0.25 & 92 & 5.17 & 4.43 \\ 3.00 & 0.25 & 97 & 5.42 & 4.45\end{array}$




\section{TABLE A.1. (contd)}

\section{Activity}

E. Preparation for Departure (contd)

15. Install front tie-down binders

16. Install trunnion guide assembly

17. Install shock absorbing covers

18. Install trunnion impact limiters

19. Roll out protective cover

20. Attach security seals

21. Complete dose rate surveys

22. Move through Gate \#1 to TSMT tractor

23. Attach TSMT tractor to trailer

24. State Police, QC Inspection

25. Close rear of protective cover

26. Attach cover tie-down cords

27. Complete and sign forms

Total Cumulative Clock Time

14.12 hours

C/E--Crane Enclosure

D/B--Decontamination Building

F/B--Fuel Building and Spent Fuel Storage Pool

\begin{tabular}{|c|c|c|c|c|c|c|c|c|c|}
\hline & & & & Average & Dose & General & & & Cumulative \\
\hline & & & Time & Distance & Rate & Area & & Cumulative & General \\
\hline & Crew & Support & in & from & from & Dose & Cumulat ive & Dose & Area \\
\hline ea & $\begin{array}{l}\text { Members } \\
\text { Required }\end{array}$ & $\begin{array}{l}\text { Menbers } \\
\text { in Area }\end{array}$ & $\begin{array}{l}\text { Area } \\
\text { (min) }\end{array}$ & $\begin{array}{l}\text { Cask } \\
(\mathrm{ft})\end{array}$ & $\begin{array}{c}\text { Cask } \\
(\mathrm{mR} / \mathrm{Hr})\end{array}$ & $\begin{array}{l}\text { Rate } \\
(\mathrm{mR} / \mathrm{Hr})\end{array}$ & $\begin{array}{l}\text { Clock Time } \\
\text { (min) }\end{array}$ & $\begin{array}{c}\text { from Cask } \\
\text { (mR) }\end{array}$ & $\begin{array}{l}\text { Dose } \\
\text { (mRR) }\end{array}$ \\
\hline
\end{tabular}

$C / E$

C/E

C/E

$C / E$

$C / E$

C/E

C/E

Yard

Yard

Yard

Yard

Yard

Yard

Required in Area (min)

(ft)

$(\mathrm{mR} / \mathrm{Hr})$

$(\min )$

(mR)

(mR)

1
2
3
1
4
1
2
1
4
2
2
1
8

$\begin{array}{rr}0 & 5 \\ 0 & 5 \\ 0 & 20 \\ 0 & 5 \\ 2 & 5 \\ 0 & 5 \\ 0 & 15 \\ 0 & 15 \\ 0 & 10 \\ 0 & 15 \\ 0 & 10 \\ 0 & 10 \\ 0 & 15\end{array}$

$\begin{array}{ll}3.00 & 0.25 \\ 3.00 & 0.25 \\ 2.00 & 0.25 \\ 2.00 & 0.25 \\ 2.00 & 0.25 \\ 3.00 & 0.25 \\ 2.00 & 0.25 \\ 0.00 & 0.00 \\ 0.00 & 0.00 \\ 0.00 & 0.00 \\ 0.00 & 0.00 \\ 0.00 & 0.00 \\ 0.00 & 0.00\end{array}$

97
97
117
102
107
112
127
142
152
167
177
187
202

5.67

4.48

4.52

4.77

4.79

4.91

4.93

5.06

5.06

5.06

5.06

5.06

5.06

5.06 
APPENDIX B

IN-TRANSIT DATA COLLECTION 


\section{APPENDIX B}

\section{IN-TRANSIT DATA COLLECTION}

The data collection forms used and the in-transit data collected during the shipment are presented in this appendix. The following subsections of this appendix describe the data collection forms and the proposed use of the data collected.

\section{B.1 IN-TRANSIT DATA COLLECTION FORM}

The forms shown in Figure B.1 were intended to be used for collecting data during the shipment. These forms were attached to the stops data collection forms and were intended to be used between each stop. However, adequate space was not provided for the data, so a $\log$ book was used.

\section{B.2 IN-TRANSIT DATA}

The in-transit data are shown in Table B.l and are a compilation of the data entered into the log book. Brief summaries have been provided at the end of the data sheets.

\section{B.3 STOPS DATA COLLECTION FORM}

This form, shown in Figure B.2, was used to collect data at each stop during the shipment. This form provided adequate space to enter data and to sketch the location of the shipment, with respect to buildings, other vehicles, and individuals in the immediate vicinity.

\section{B.4 STOPS DATA}

These data are shown in Table B.2 and are a compilation of the data entered on each of the stops data collection forms. 
I General

i. Date:

2. Name:

3. Route Segment: Origin

4. Time at Origin:

End-point

Approximate Elapsed Time

5. Odomeier Reading at Origiri of Route Segment

II Soecific

1. Approximate pcpulation distributions (Record approximate) Distances or Odome:ar Readings for Each Zone

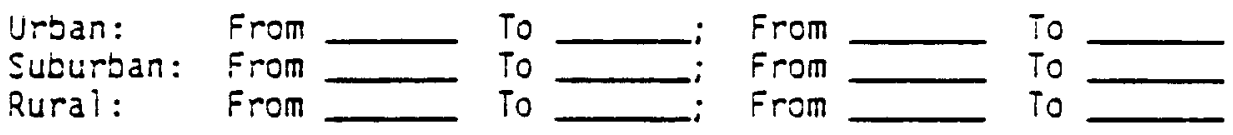

2. Note names of large cities $(>100,000)$ traversed and indicate yes or no if bypass ivas used.

3. Note number of times and durations of heavy trafic conditions (vehicle slows to $40 \mathrm{mph}$ ).

$\longrightarrow$

4. Note number of times and approximate durations of szoos in traffic.

5. Average number and distance from oncoming lanes (i.e., divided hignway or not)

6. At several points elong the route, count the number of vehicles in the same and opcosing lares of trafic per unit time.

FIGURE 8.1. In-Transit Data Collection Forms 
7. Miscellaneous Obserations

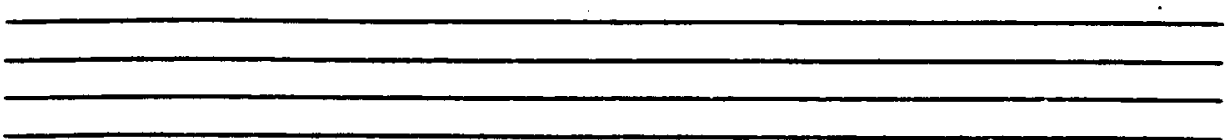

FIGURE 6.1. Continued

B.3 
TABLE B.1. In-Transit Data

\begin{tabular}{|c|c|c|c|c|c|c|c|c|c|c|}
\hline $\begin{array}{l}\text { Odometer } \\
\text { In }\end{array}$ & $\begin{array}{c}\text { Reading } \\
\text { Out }\end{array}$ & $\begin{array}{l}\text { Vehicl } \\
\text { Same } \\
\text { Direction }\end{array}$ & $\begin{array}{l}\text { Count } \\
\text { Opposing } \\
\text { Direction }\end{array}$ & $\begin{array}{l}\text { Rest } \\
\text { Same } \\
\text { Direction }\end{array}$ & $\begin{array}{l}\text { Area } \\
\text { Opposing } \\
\text { Direction }\end{array}$ & $\begin{array}{l}\text { Road } \\
\text { Crew }\end{array}$ & Misc. & $\begin{array}{l}\text { Popula } \\
\text { Rural }\end{array}$ & $\begin{array}{l}\text { ation Zone } \\
\text { Suburban }\end{array}$ & $\begin{array}{l}\text { (a) } \\
\text { Urban }\end{array}$ \\
\hline $\begin{array}{r}42655 \\
42924 \\
43030 \\
43044 \\
43224 \\
43291 \\
43452 \\
43626 \\
43784 \\
\square \quad 43962 \\
\quad 44196 \\
44286 \\
44492 \\
44713 \\
44858 \\
44961 \\
45072 \\
45171 \\
45362\end{array}$ & $\begin{array}{l}42924 \\
43030 \\
43044 \\
43224 \\
43291 \\
43452 \\
43626 \\
43784 \\
43962 \\
44196 \\
44286 \\
44492 \\
44713 \\
44858 \\
44961 \\
45072 \\
45171 \\
45362 \\
45462\end{array}$ & $\begin{array}{r}14 \\
37 \\
0 \\
9 \\
0 \\
2 \\
7 \\
6 \\
3 \\
11 \\
4 \\
4 \\
0 \\
1 \\
1 \\
0 \\
4 \\
3 \\
7\end{array}$ & $\begin{array}{r}120 \\
281 \\
56 \\
125 \\
8 \\
43 \\
77 \\
173 \\
214 \\
119 \\
143 \\
45 \\
0 \\
54 \\
33 \\
0 \\
69 \\
57 \\
61\end{array}$ & $\begin{array}{r}0 \\
10 \\
5 \\
11 \\
0 \\
12 \\
79 \\
9 \\
4 \\
26 \\
0 \\
56 \\
27 \\
17 \\
2 \\
4 \\
1 \\
11 \\
0\end{array}$ & $\begin{array}{c}23 \\
16 \\
3 \\
8 \\
0 \\
6 \\
50 \\
12 \\
39 \\
15 \\
0 \\
0 \\
6 \\
14 \\
3 \\
4 \\
0 " \\
3 \\
0 "\end{array}$ & $\begin{array}{r}28 \\
29 \\
0 \\
0 \\
0 \\
0 \\
0 \\
43 \\
4 \\
50 \\
0 \\
0 \\
0 \\
0 \\
0 \\
0 \\
0 \\
0 \\
0\end{array}$ & $\begin{array}{r}12 \\
0 \\
0 \\
0 \\
0 \\
0 \\
0 \\
0 \\
21 \\
0 \\
0 \\
0 \\
0 \\
0 \\
0 \\
0 \\
0 \\
0 \\
0\end{array}$ & $\begin{array}{r}261 \\
87 \\
1 \\
127 \\
49 \\
128 \\
148 \\
144 \\
159 \\
214 \\
79 \\
187 \\
211 \\
126 \\
102 \\
107 \\
92 \\
179 \\
87\end{array}$ & $\begin{array}{r}8 \\
19 \\
10 \\
47 \\
16 \\
28 \\
13 \\
8 \\
19 \\
20 \\
8 \\
16 \\
10 \\
9 \\
1 \\
4 \\
7 \\
12 \\
13\end{array}$ & $\begin{array}{r}0 \\
0 \\
3 \\
6 \\
2 \\
5 \\
13 \\
6 \\
0 \\
0 \\
3 \\
3 \\
0 \\
10 \\
0 \\
0 \\
0 \\
0 \\
0\end{array}$ \\
\hline
\end{tabular}


I COENERAL

1. Date

2. Name

3. Time In:

Time out:

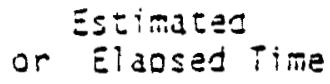

4. Rezson for Stcp:

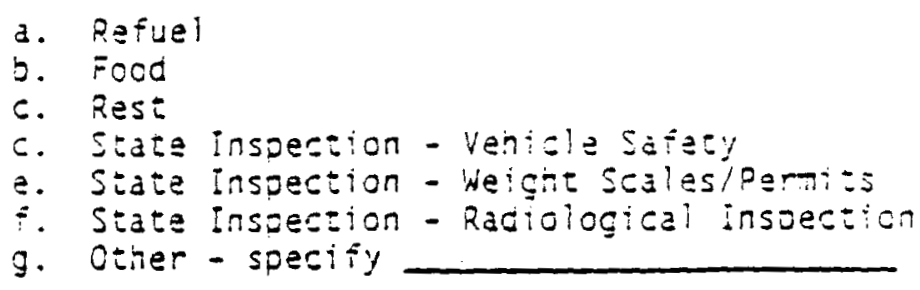

b. Food

c. Rest

c. State inspection - Venicle Saftey

e. State Inspection - weicnt Scales/permi:s

$\because$ State Inspection - Radiological insuection

g. Other - specity

5. Location:

5e: Urian Eb: Suburban Sc: Rura!

5. Ccometar Reading:

II SPECIFIC

1. Oraw general iayous of stoo. Note as closely as possibit the foliowing items:

a. Location of cEsk-venicle

b. Locations of sulidings; distance between cask and buildincs

c. Locacions of nazrest permanent resident; estimate distance co cask

d. Locations of other Darked venicles

e. Shielding prowided by buildings, structures, etc. (material and thickness)

FIGURE 8.2. Stops Data Collection Forms 
2. Attach Photographs

3. Activities: Note as closely as possibie the number of persons excosed, the exposure distance, and exposure time.

a. Refueling:

Time In:

Time Out:

Time in Queue: No. of Vehicles in Line:

Performed by (circle One): Attendant(s) or Driver(s) Estimated distance from cask

Remarks:

D. Vehicle Safety Inspection

List Items Insp̣ected:

Oriver(s) Activities/Location

Time in Queve:

No. of Venicles Ahead of Cask

Estimated Time:

Number of Inspectors:

Estimated Oistance from Cask:

Remarks:

c. Weight Scales/Permits

Time in:

Time Out:

Elapsed Time (Estimate)

Time in Queue:

Number of venicles in front of cask-vehicle

Estimated Distence(s) to person(s)

Total Number of persons:

Oriver(s) Activities/Locations:

Remarks:

FIGURE B.2. Cont inued 
d. Radiological Inspections

Time in:

Time Cut:

Elapsed Time (astimate)

List activities and approximate times for each

Lisi disiance :rom cask for each detivity

Number of persons involved in inspection

Number of Dersons other than driver(s) and inspector(s)

Remarks:

e. Rest Stops Only (Biological relief, etc)

Approximate elapsed time

No. of persons at stop

Distance from cask to persons

Remarks:

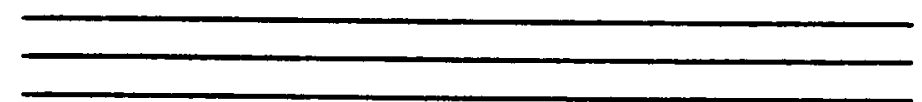

f. Other activitiss (Describe triefly; include estimates of time, manpcier, distance to cask, and driver(s)

FIGURE B.2. Continued 
TABLE B.2. TN8L In-Transit Stops Data

$\stackrel{\infty}{\infty}$

\begin{tabular}{|c|c|c|c|c|c|c|c|}
\hline $\begin{array}{l}\text { STop } \\
\text { ho }\end{array}$ & DAIE & ODOMETER & IYPE & IIUE-IH & $\begin{array}{l}\text { ELAPSED } \\
\text { IIUE-UIM. }\end{array}$ & REASOH & COLNENIS \\
\hline 1 & $1 / 21 / 86$ & $x x x x x x x$ & SURAY NIPP & N. A. & $x \times x \times x$ & SIART & 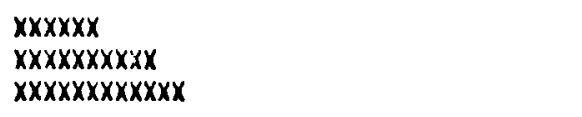 \\
\hline 2 & $4 / 21 / 88$ & $x x x x x$ & $x x x x$ & $x x$ & $x$ & $x \mathbf{x x x}$ & $\begin{array}{l}x x x x \\
x x x\end{array}$ \\
\hline 3 & $1 / 21 / 86$ & 13077 & REST AHEA & $x x x$ & $x x x$ & CAIL-IH & $\begin{array}{l}\text { OQ FI FROU BUILDIHG } \\
\text { AVE. IO FI FROM } \\
6 \text { VEIICIES }\end{array}$ \\
\hline 1 & $1 / 25 / 86$ & 43289 & IRUCK STOP & 12:60 PU & $8 \theta$ & REFU日. & $\begin{array}{l}\text { YITHIN } 30 \text { FI FRON } \\
\text { VEHICLES IN BAY AREA }\end{array}$ \\
\hline 5 & $1 / 25 / 86$ & 43188 & REST AREA & 3:18 AU & 1 & & 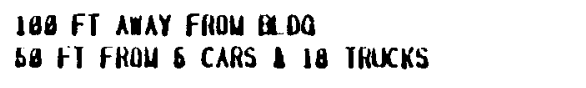 \\
\hline 6 & $1 / 25 / 86$ & 13856 & timuck stap & 12:08 Pu & 23 & REFUE & $\begin{array}{l}\text { B RIGS NEAR IRUCK } \\
\text { 6O PEOPLE IN MEARBY RESTAURANT } \\
\text { REFUELING I CIIECKING DONE AI 12:15 }\end{array}$ \\
\hline 7 & $1 / 25 / 86$ & & yI STAIION & $12: 18 \mathrm{PM}$ & 2 & $\begin{array}{l}\text { SIATE IHSP- } \\
\text { VEIICIE }\end{array}$ & $\begin{array}{l}\text { HO rHUCKS IN LINE } \\
2 \text { IRICKS IN LOT }\end{array}$ \\
\hline 8 & $1 / 25 / 86$ & & IHS SIATION & 2:30 Pu & & $\begin{array}{l}\text { SIAIE INSP- } \\
\text { VEHICLE }\end{array}$ & 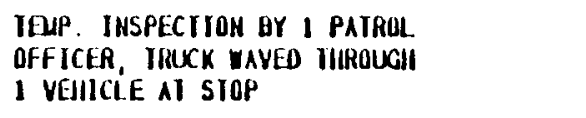 \\
\hline 9 & $1 / 26 / 80$ & 14001 & REST AREA & $3: 14 \mathrm{PH}$ & & CALI-IN & CALILE IH, 12 VEIICLES IM PK. ARES \\
\hline 18 & $1 / 25 / 80$ & 11132 & IRUCK STOP & 6:16 PH & 28 & $\begin{array}{l}\text { REFUEI. } \\
\text { CAl I.-IN }\end{array}$ & $\begin{array}{l}\text { REFUE ED AND CIIECKED, 3 RIGS QESIDE } \\
\text { IRUCK, IS PEOPEE IN SIORE AD JACEMI }\end{array}$ \\
\hline 11 & $1 / 25 / 80$ & & RESTAURAMI & $7: 09 \mathrm{PU}$ & 28 & Fuod & $\begin{array}{l}2 \text { IRUCKS YITHIN } 10 \text { FI OF SIIIPUENT } \\
\text { 2J PEOPLE IH RESTAURANT IITHIN BO FI }\end{array}$ \\
\hline 12 & $4 / 25 / 06$ & & rOLL. SIACIOH & & 3 & Tull. Danoril & $\begin{array}{l}\text { 1 PERSON AT TOH SHATION } \\
\text { GOGIII WAS I FI FROA IRUCK }\end{array}$ \\
\hline 13 & 1/25/86 & 11222 & REST AREA & & 24 & $\begin{array}{l}\text { DRIVER SWIICH } \\
\text { WEAHEA HEES }\end{array}$ & 6 VEHICLES WITIIL $18 \mathrm{FT}$ \\
\hline 14 & $1 / 26 / 86$ & 11170 & IRIKK STOP & $12: 68 \mathrm{PH}$ & 17 & Rave. & 6 IAMCKS MFAHOY \\
\hline 15 & $1 / 25 / 66$ & & IRKKK stap & $3: 26 \mathrm{AH}$ & 21 & RH:H & 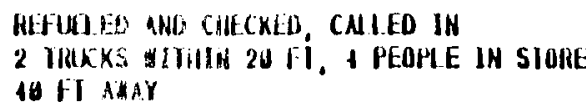 \\
\hline
\end{tabular}


IABLE B.2. (Contd.)

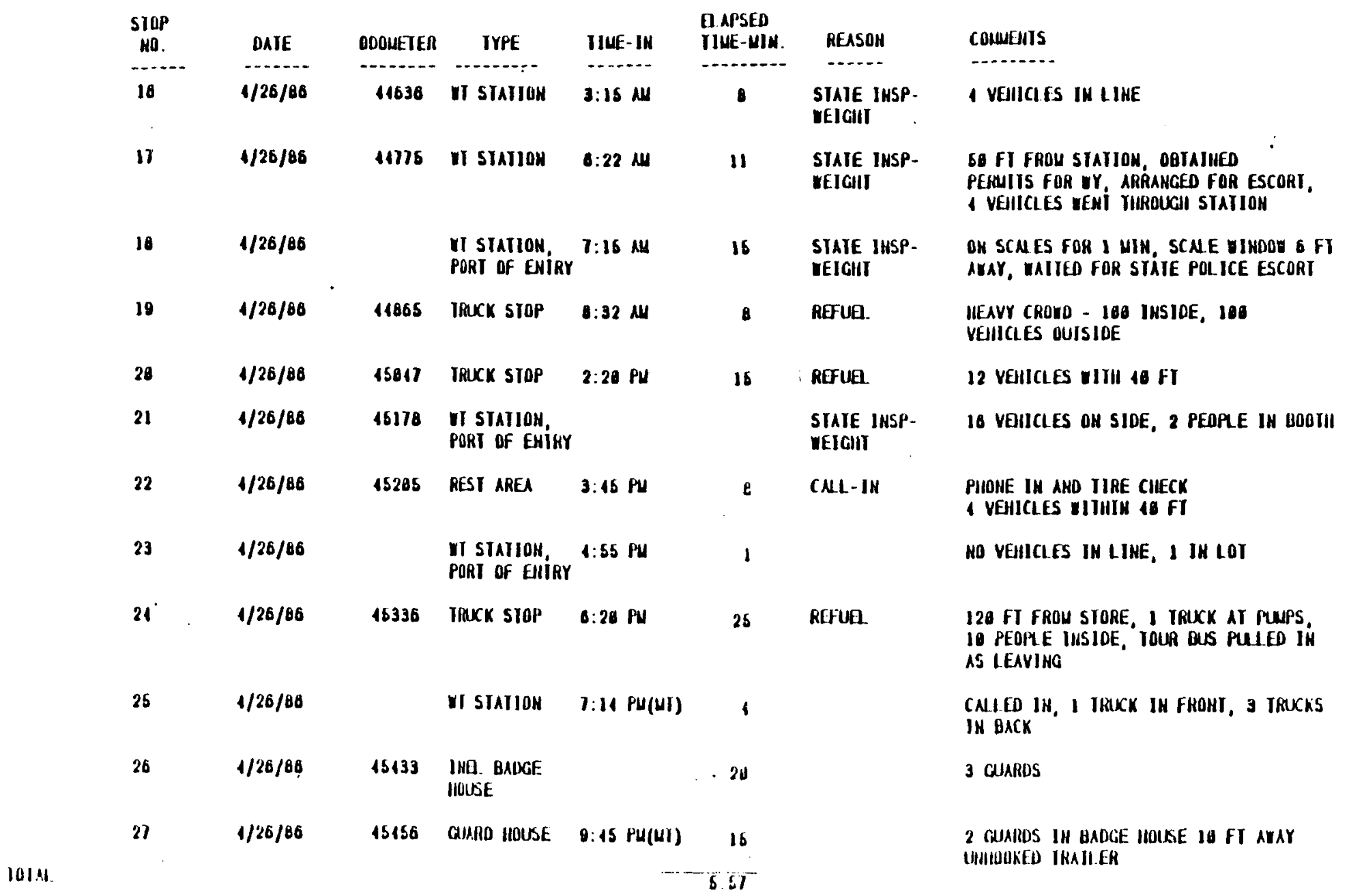


APPENDIX C

CALCULATION OF IN-TRANSIT AND STOPS EXPOSURES TO THE PUBLIC 
APPENDIX C

\section{CALCULATION OF IN-TRANSIT AND STOPS EXPOSURES TO THE PUBLIC}

This appendix discusses the methods used to calculate occupational and public doses during the shipment. These analyses utilize the data described in Appendix $B$ and the dose rate maps provided by VEPCO. Exposure data was not measured for the occupants of the truck; therefore, the radiation dose rate of $0.3 \mathrm{mrem} / \mathrm{hr}$, measured at a distance of $20 \mathrm{ft}$ from the end of the cask, is used for calculational purposes. The occupational doses received by at-reactor and INEL cask handlers are discussed in Chapters 2.0 and 4.0.

The routine occupational exposures received by the public have been calculated based on the formula presented by Greenborg et al. (1980, Appendix C). The calculated doses are based on the dose rate map provided by Surry Power Station and the dimensions of a typical two-lane and four-lane highway or interstate (see Figure 3.3). The Surry Power Station dose rates have been used to characterize the spent fuel shipment with respect to the variable value " $k$ " used to calculate the dose to the public. The "k" factor is based on the age of the spent fuel and the shipping cask used.

\section{FORMULA USED TO CALCULATE EXPOSURES TO THE PUBLIC}

The following formulas are used to calculate the in-transit dose to the public traveling in vehicles that have passed the shipping cask. These same formulas have been used to calculate the dose to the public at rest areas and weigh stations passed by the truck (i.e., $v_{b}=0$ ).

Dose to travelers

in the same direction

$$
\text { DTS }=\frac{(2 k L N T)}{\left|V_{a}-V_{b}\right|} \cdot I_{1}(y)
$$

Dose to travelers in the opposite direction

$$
\text { DTO }=\frac{(2 k L N T)}{V_{a}+V_{b}} \cdot I_{1}(y)
$$




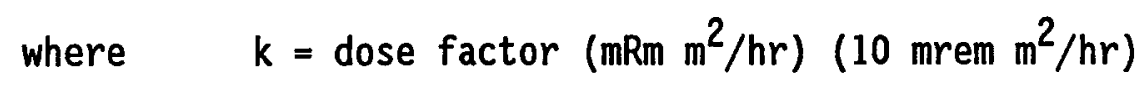

$$
\begin{aligned}
\mathrm{L}= & \text { route segment length }(4.52 \mathrm{E}+06 \mathrm{~m}) \\
\mathrm{N}= & \text { average number of people/vehicle (1.4 passengers/vehicle) } \\
\mathrm{T}= & \text { traffic count (vehicles/m) } \\
\mathrm{V}_{\mathrm{a}}= & \text { shipment velocity }(\mathrm{m} / \mathrm{hr}) \text { (average velocity is } 5 \mathrm{mi} / \mathrm{hr} \text { and is } \\
& \text { assumed to be constant) } \\
\mathrm{V}_{\mathrm{b}}= & \text { target vehicle velocity }(\mathrm{m} / \mathrm{hr} \text { ) (average velocity is } 52 \mathrm{mi} / \mathrm{hr} \\
& \text { and is assumed to be constant) } \\
\mathrm{I}_{1}(\mathrm{y})= & \text { integral estimating the dose to a moving or stationary target } \\
& \text { at some distance }(\mathrm{y}) \text { in feet from the shipping cask (m) } \\
& \text { (see Figure C.1). }
\end{aligned}
$$

The dose to the area normally occupied by the public is dependent on the distance that the normally occupied area is from the shipping cask. The formula used to calculate the dose to the public; based on population densities, is as follows:

$$
\text { DTP" }=\frac{(4 k P L)}{V_{a}} \cdot I_{2}(d)
$$

where

$$
\begin{aligned}
& k=\text { dose factor }\left(\mathrm{mRm} \mathrm{m} \mathrm{m}^{2} / \mathrm{hr}\right)\left(10 \mathrm{mrem} \mathrm{m}^{2} / \mathrm{hr}\right) \\
& \text { P" = population densities (people/ } / \mathrm{m}^{2} \text { ) (Rhoads, Franklin and } \\
& \text { Lavender 1986) } \\
& \begin{array}{ll}
\text { rural } & =8.5 \mathrm{E}-06 \text { people } / \mathrm{m}^{2} \\
\text { suburban } & =6.9 \mathrm{E}-05 \text { people } / \mathrm{m}^{2} \\
\text { urban } & =1.6 \mathrm{E}-03 \text { people } / \mathrm{m}^{2}
\end{array} \\
& \mathrm{~L}=\text { length of route segment in each population zone }(\mathrm{m}) \\
& \text { rural }=3.99 \mathrm{E}+06 \mathrm{~m} \\
& \text { suburban }=4.34 \mathrm{E}+05 \mathrm{~m} \\
& \text { urban }=8.05 \mathrm{E}+04 \mathrm{~m} \\
& v_{a}=\text { shipment velocity }(\mathrm{m} / \mathrm{hr} \text { ) (average velocity is } 50 \mathrm{mi} / \mathrm{hr} \\
& \text { and is assumed to be constant) } \\
& I_{2}(d)=\text { integral estimating the dose to the edge of each population } \\
& \text { zone (30 feet) (see Figure C.2). }
\end{aligned}
$$

C.2 


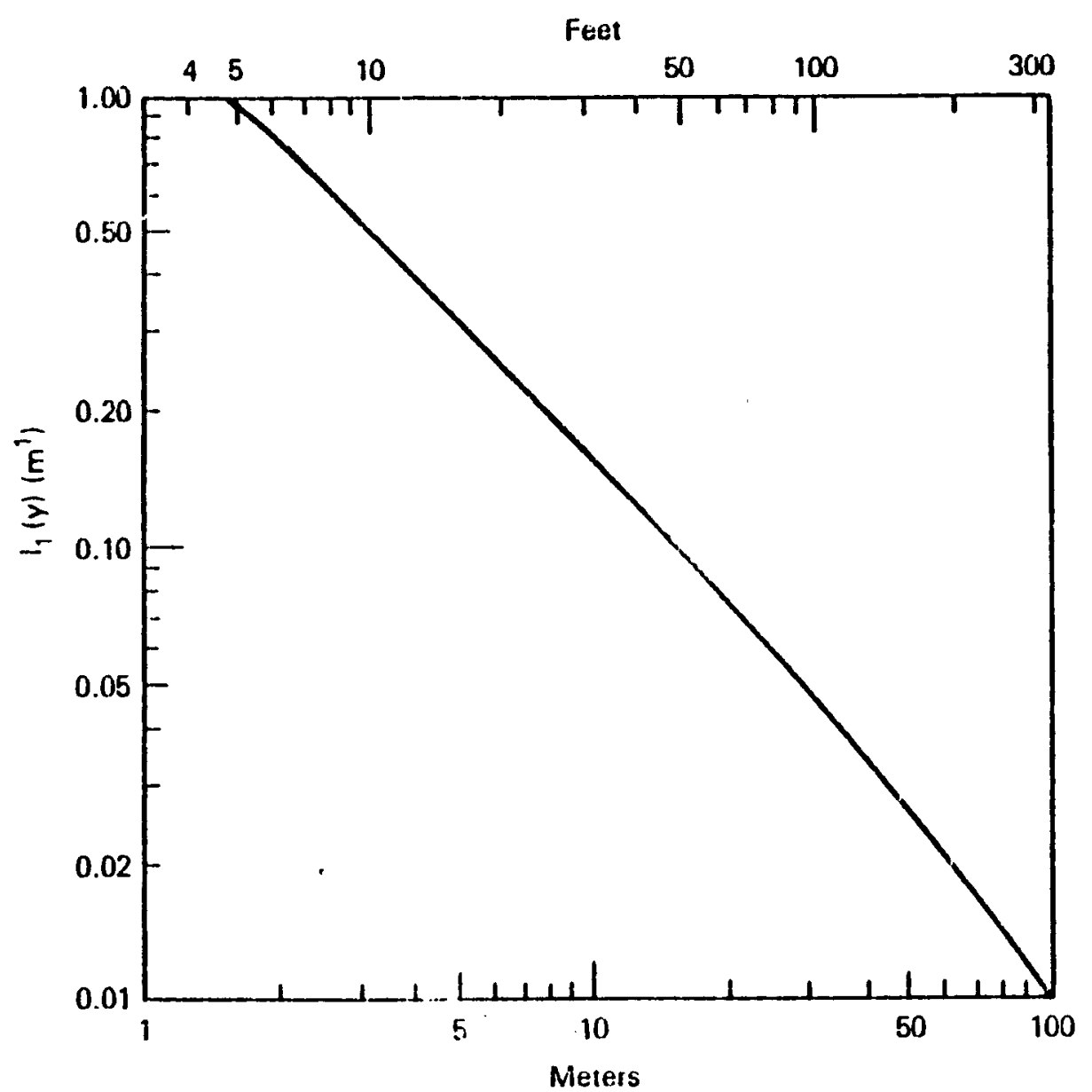

Distance, $y$

FIGURE C.1. $I_{1}(y)$ as a Function of $y$

C.3 


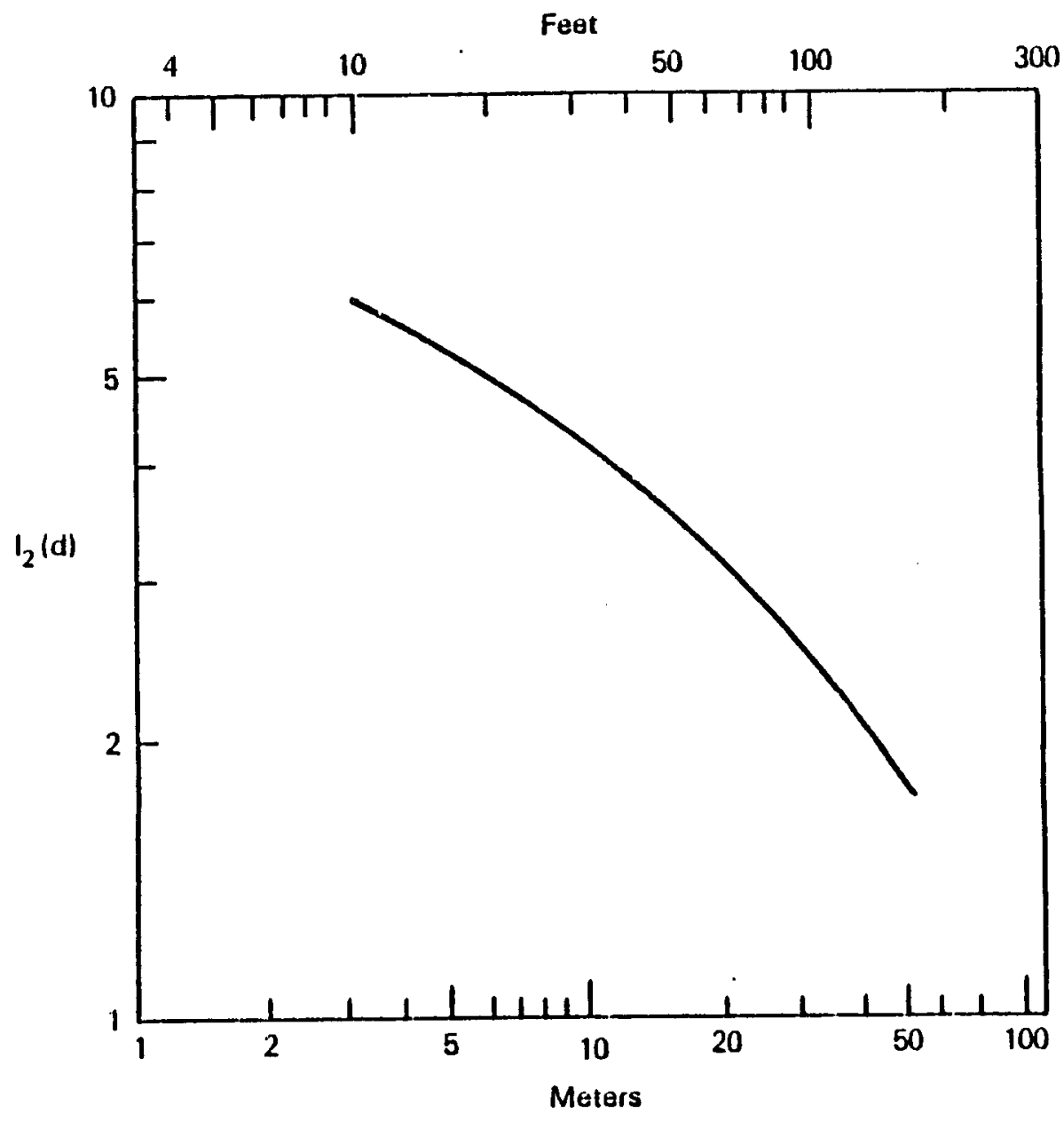

Distance, d

FIGURE C.2. $I_{2}(d)$ as a Function of $d$

The shipment stopped 26 times enroute from the Surry Power Station to the INEL-TAN facility. The dose to the public at each of the 26 stops includes the doses received by persons employed at each location, persons in the vicinity of the cask, people eating in restaurants or people stopped at rest areas. The categories or types of individuals exposed at each of the stops have been divided into five categories.

The formula used to calculate the dose to the public for each category of stop is as follows: 
Dose to persons in

the vicinity of the cask

$$
P I V=\frac{(k N T P)}{d^{2}}
$$

where $k=$ dose factor $\left(\mathrm{mRm} \mathrm{m}^{2} / \mathrm{hr}\right)\left(203 \mathrm{mrem} \mathrm{m}^{2} / \mathrm{hr}\right)$

$P=$ estimated number of individuals at each stop

$T=$ the average time spent at each stop (hr)

$N=$ number of stops per category

$V=$ number of vehicles at each stop

$d$ = distance separating shipping cask and individuals.

\section{In-Transit Dose Calculations}

The in-transit public doses have been calculated for occupants of vehicles traveling in the same direction (passing vehicles only, occupants of vehicles traveling in the opposite direction, and occupants of vehicles stopped along the highway or interstate. Three of the previously described formulas have been used to calculate the in-transit public doses. The formulas used and their applications are:

Formula (C.1) To calculate the dose to the occupants of vehicles traveling in the same direction as the shipment and to calculate dose to occupants of vehicles stopped along side the highway or interstate.

Formula (C.2) To calculate the dose to the occupants of vehicles traveling in the opposite direction as the shipment and to calculate dose to occupants of vehicles stopped along side the highway or interstate.

Formula (C.3) To calculate the dose to the general public based on three population densities: rural, suburban, and urban.

Table C.I presents the data collected and the values used to calculate in-transit public doses.

C. 5 
TABLE C.1. Data Collected for In-Transit Dose Calculations

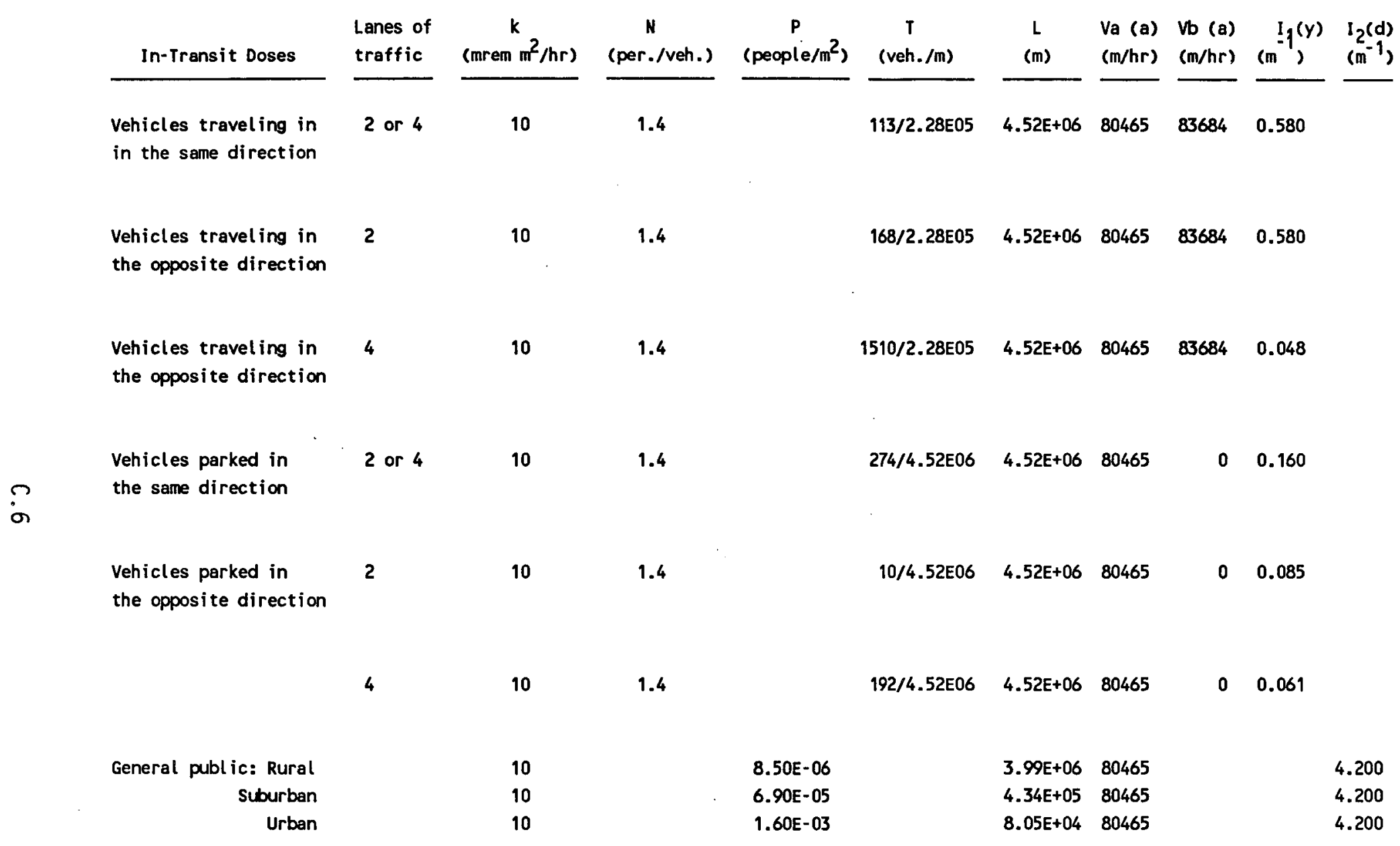

(a) Velocities are assumed to be constant. 


\section{Stops Dose Calculations}

Doses have been calculated to the general public in the vicinity of the shipping cask during enroute stops at weigh stations, truck stops, etc. Formula C.4 has been used to calculate the exposure to the general public at these stops. Table C.2 lists the data for each category of stop based on the number of vehicles and the estimated number of people at each stop used to calculate public doses.

Driver Occupational Dose Calculations

Occupational doses were calculated using the rate of $0.3 \mathrm{mrem} / \mathrm{hr}$ in the crew compartment. The crew consisted of two truck drivers: a driver and a replacement. It was assumed for calculational purposes that one driver was in the crew compartment for the entire 62 hours and the replacement driver was in the crew compartment for 57.5 hours. It was assumed that 4.5 hours were required for the replacement driver to refuel the vehicle and order meals. 
IABLE C.2. Data Used to Calculate Public Doses at Stops

\begin{tabular}{|c|c|c|c|c|c|c|}
\hline Category of Stop & $\begin{array}{c}\text { N } \\
\text { (\# stops) }\end{array}$ & $\underset{\left(m r e m . m^{2} / h r\right)}{k}$ & $\begin{array}{c}P \\
\text { (people) }\end{array}$ & $\begin{array}{c}V \\
\text { (vehicles) }\end{array}$ & $\begin{array}{c}{ }^{\top} \\
\text { (avg. hrs) }\end{array}$ & $\begin{array}{c}d \\
(m)\end{array}$ \\
\hline \multirow{3}{*}{$\begin{array}{l}\text { Weigh Station } \\
\qquad \text { (Tenn. Dor) } \\
\text { (a) }\end{array}$} & 9 & 2.03 & 2 & \multirow[t]{3}{*}{33} & 0.08 & 1.83 \\
\hline & 1 & 2.03 & 1 & & $0 . \overline{3}$ & 0.82 \\
\hline & 1 & & 1 & & 0.05 & 1.83 \\
\hline Rest Area & 5 & 2.03 & & 49 & 0.13 & 61.00 \\
\hline Truck Stops $^{(c)}$ & 9 & 2.03 & 284 & & 0.41 & 76.20 \\
\hline Other vehicles fuel ing & & & & 2 & & 6.10 \\
\hline other vehicles parked & & & & 31 & & 61.00 \\
\hline Badge House(d) & 2 & 2.03 & 5 & & 0.29 & 3.05 \\
\hline Individual near cask ${ }^{(e)}$ & 26 & 2.03 & 1 & & 0.34 & 3.90 \\
\hline
\end{tabular}

\footnotetext{
(a) One Tennessee DOT Inspector.

(b) One vehicle inspection.

(c) Includes one restaurant stop.

(d) These are occupational, but are included in this analys is because of the data collection methods.

(e) One person in the vicinity of the cask at all stops.
} 
APPENDIX D

TN-8L CASK HANDLING--HOT SHOP UNLOADING 
TABLE D.1. TN-8L Shipping Cask Unloading

\begin{tabular}{|c|c|c|c|c|c|c|c|c|}
\hline \multirow[b]{3}{*}{ Activity Steps } & \multirow{3}{*}{$\begin{array}{c}\text { Area } \\
\text { Dose Rate }\end{array}$} & \multicolumn{2}{|c|}{ Staff } & \multicolumn{2}{|c|}{ Activity } & & \multirow[b]{2}{*}{ Dose Rate for } & \multirow[b]{2}{*}{ Doses (person-mrem) } \\
\hline & & \multirow{3}{*}{$\begin{array}{c}\text { Total } \\
\text { Number } \\
\text { in } \\
\text { Area }\end{array}$} & \multirow{2}{*}{$\begin{array}{l}\text { Number } \\
\text { Doing } \\
\text { Cask }\end{array}$} & & & & & \\
\hline & & & & In & Near & From Cask & Cask Work & Cask Gen. \\
\hline Description & (mrem/hr) & & Hork & Area & Cask & in Feet & (mrem/hr) & Work Area \\
\hline
\end{tabular}

1.0 TN-8L Cask Receipt

1.1 Persomel Barrier

Positioned and Secured

1.2 RM Obtains Swipes, Uses Hand Meld Monitor

1.3 Check Security Seals

$\begin{array}{llllll}0.2 & 5 & 5 & 5 & 5 & 3 \\ 0.2 & 5 & 1 & 18 & 18 & 3 \\ 0.2 & 5 & 1 & 16 & 16 & 5\end{array}$

Elapsed Time $=39 \mathrm{~min}$

2.0 Preparation for Unloading TN-8L Cask

2.1 Open Hot Shop Doors (Remote)

2.2 Position Truck in Hot Shop

2.3 Rear Impact Limiter Renoved

2.4 Front Impact Limiter Removed

2.5 Remove Rear Trunnion Protectors and Tiedowns, Grease Trunnions
2 
TABLE D.1. (contd.)

\begin{tabular}{|c|c|c|c|c|c|c|c|c|c|c|c|}
\hline & & & Sta & & Act & & & & & & \\
\hline & & Area & $\begin{array}{l}\text { Total } \\
\text { Number }\end{array}$ & $\begin{array}{l}\text { Number } \\
\text { Doing }\end{array}$ & $\begin{array}{r}\mathrm{Tin} \\
\text { in } \mathrm{Mir}\end{array}$ & & $\begin{array}{l}\text { Hork } \\
\text { Distance }\end{array}$ & Dose Rate for & Doses & Sperso & -mrem) \\
\hline & Activity Steps & Dose Rate & in & Cask & In & Near & From Cask & Cask Work & Cask & Gen. & \\
\hline No. & Description & (mrem/hr) & Area & Hork & Area & Cask & in Feet & - (mrem/hr) & Hork & Area & Iotal \\
\hline 2.6 & $\begin{array}{l}\text { Remove Front Trumnion } \\
\text { Protectors and Tiedowns, } \\
\text { Grease Trunnions }\end{array}$ & 2 & 5 & 2 & 3 & 3 & 1 & 1.2 & 0.1 & 0.5 & 0.6 \\
\hline 2.7 & $\begin{array}{l}\text { Upend Cask and Remove from } \\
\text { Trailer }\end{array}$ & 2 & 5 & 2 & 37 & 16 & 3 & 0.7 & 0.4 & 6.2 & 6.6 \\
\hline 2.8 & $\begin{array}{l}\text { Truck Moves Out of Hot Shop } \\
\text { and Hot Shop Door is Closed }\end{array}$ & 2 & 5 & 0 & 2 & 0 & - & 0.0 & 0.0 & 0.3 & 0.3 \\
\hline 2.9 & Radiation Survey of Trailer & 2 & 1 & $\mathbf{0}$ & 6 & 0 & - & 0.0 & $\underline{0.0}$ & $\underline{0.2}$ & 0.2 \\
\hline & & & Elap & sed Time & $=74 \mathrm{~m}$ & & & & 1.3 & 10.8 & 12.8 \\
\hline 3.0 & $\begin{array}{l}\text { Preparing the TN-8L Cask for } \\
\text { Fuel Transfer }\end{array}$ & & & & & & & & & & \\
\hline 3.1 & $\begin{array}{l}\text { Install Contamination } \\
\text { Control Plastic }\end{array}$ & 10 & 5 & 5 & 5 & 5 & 3 & 0.7 & 0.3 & 4.2 & 4.5 \\
\hline 3.2 & Perform Gas/Pressure Test & 10 & 5 & 3 & $\underline{24}$ & 24 & 1 & 1.2 & 1.4 & $\underline{20.0}$ & $\underline{21.4}$ \\
\hline & & & Elar & sed time & $20 \mathrm{~m}$ & & & & 1.7 & 24.2 & 25.9 \\
\hline
\end{tabular}

4.0 Preparing the MC-10 for Fuel Transfer

Parallel Activity/Not Observed 


\section{TABLE D.1. (contd.)}

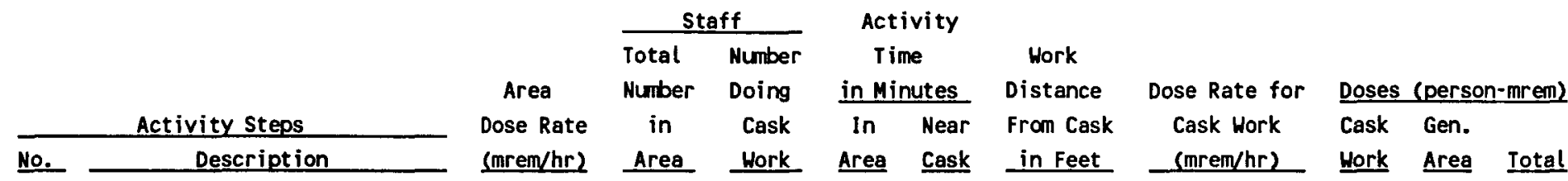

5.0 Preparing the TN-8L Cask Lid for Removal

5.1 Remove Lid Bolts

5.2 Install Lifting Adaptor

10

6.1 Install Grapple, final Area

7.0 TN-8L and MC-10 Cosks Remote Lid Removal

\footnotetext{
7.1 Remove Lids

Check
}

7.2 Install Seal Protector

Hork Area Iotal

${ }_{\omega}^{0}$

$\begin{array}{llll}1.2 & 0.5 & 4.5 & 5.0 \\ 1.2 & \underline{0.2} & \underline{1.5} & \underline{1.7} \\ & 0.7 & 6.0 & 6.7\end{array}$

0.7

$1.0 \quad 14 \quad 15$

$\begin{array}{lll}1.0 & 14 \quad 15\end{array}$
39

17

Elapsed Time $=56 \mathrm{~min}$ $\begin{array}{llll}0.0 & 0.0 & 0.0 & 0.0\end{array}$

$0.0 \quad \underline{0.0} \quad \underline{0.0} \quad \underline{0.0}$

$\begin{array}{lll}0.0 & 0.0 & 0.0\end{array}$ 
IABLE D.1. (contd.)

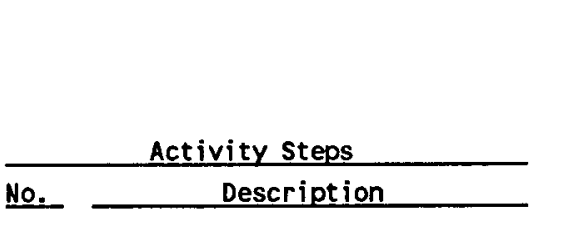

8.0 Fuel Transfer

\begin{tabular}{|c|c|c|c|c|c|c|c|}
\hline \multirow{3}{*}{$\begin{array}{c}\text { Area } \\
\text { Dose Rate } \\
\text { (mrem/hr) }\end{array}$} & \multicolumn{2}{|c|}{ Staff } & \multicolumn{2}{|c|}{ Activity } & & & \\
\hline & $\begin{array}{l}\text { Total } \\
\text { Number }\end{array}$ & $\begin{array}{l}\text { Number } \\
\text { Doing }\end{array}$ & $\begin{array}{r}\mathrm{Ti} \\
\text { in } \mathrm{Mi} \\
\end{array}$ & & $\begin{array}{c}\text { Work } \\
\text { Distance }\end{array}$ & Dose Rate for & Doses (person-mrem) \\
\hline & $\begin{array}{c}\text { in } \\
\text { Area } \\
\end{array}$ & $\begin{array}{l}\text { Cask } \\
\text { Hork } \\
\end{array}$ & $\begin{array}{c}\text { In } \\
\text { Area }\end{array}$ & $\begin{array}{l}\text { Near } \\
\text { Cask }\end{array}$ & $\begin{array}{c}\text { From Cask } \\
\text { in Feet }\end{array}$ & $\begin{array}{l}\text { Cask Work } \\
\text { (mrem/hr) }\end{array}$ & $\begin{array}{l}\text { Cask Gen. } \\
\text { Work Area }\end{array}$ \\
\hline
\end{tabular}

0
0
0

\#3 SFA Unloaded

9.0 MC-10 Basket Fuel Compartment

:

\begin{abstract}
Video Taping Not Observed
\end{abstract}
10.0 MC-10 Storage Cask Lid

Replacement

10.1 Rernove Seal Protector

10.2 Install Cask Lid

0

0

5

10

5

24

Elapsed Time $=34 \mathrm{~min}$

$\begin{array}{llll}0.0 & 0.0 & 0.0 & 0.0 \\ 0.0 & 0.0 & 0.0 & 0.0 \\ 0.0 & \underline{0.0} & \underline{0.0} & \underline{0.0} \\ & & & \\ & 0.0 & 0.0 & 0.0\end{array}$

0.0

$\begin{array}{lll}0.0 & 0.0 & 0.0\end{array}$

$\underline{0.0} \quad \underline{0.0} \quad \underline{0.0}$

$\begin{array}{lll}0.0 & 0.0 & 0.0\end{array}$

11.0 MC-10 Storage Cask Lid Securing

Not Observed

12.0 Evacuate MC-10 Cask

Parallel Activity 
TABLE D.1. (contd.)

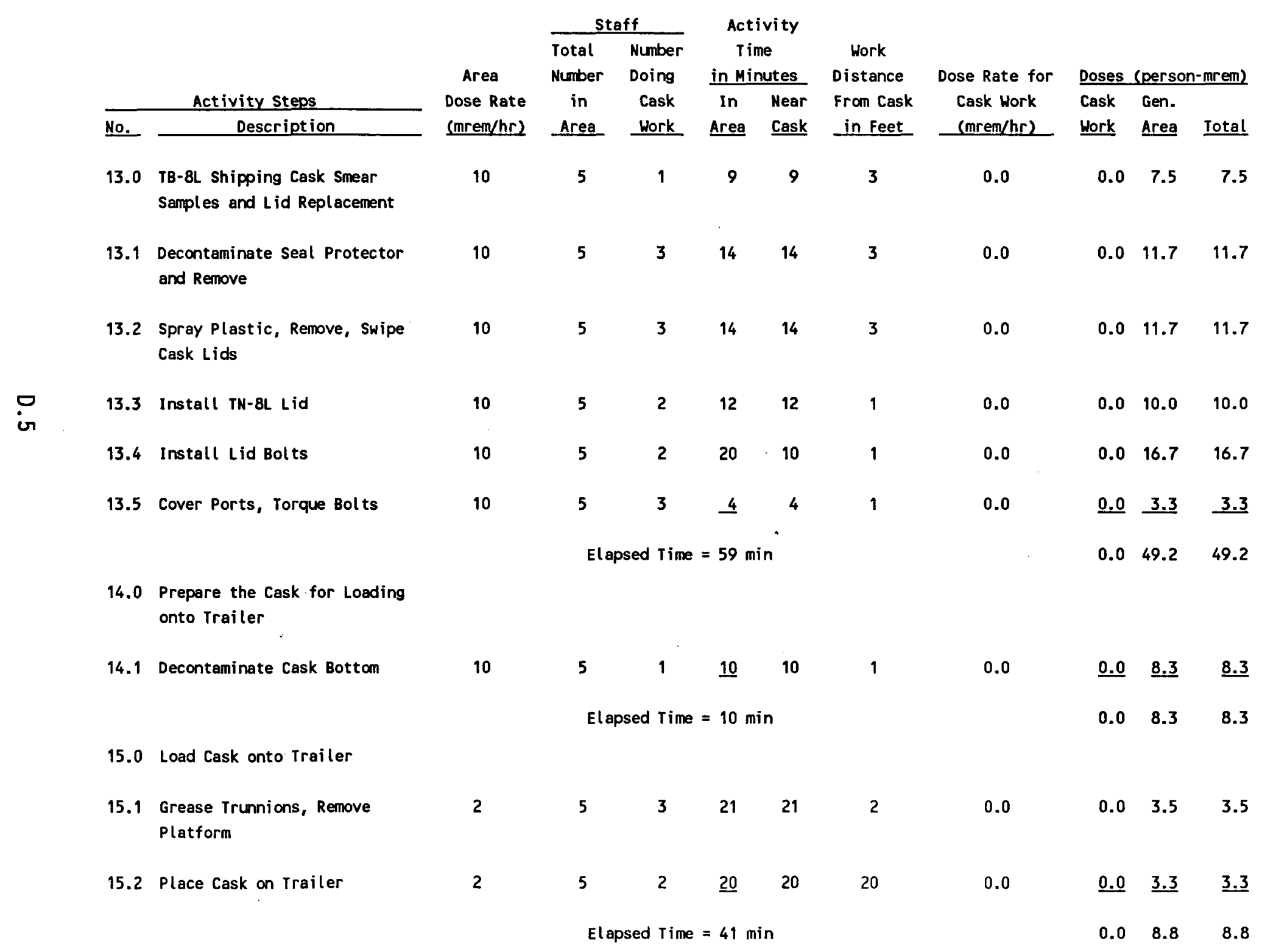




\section{TABLE D.1. (contd.)}

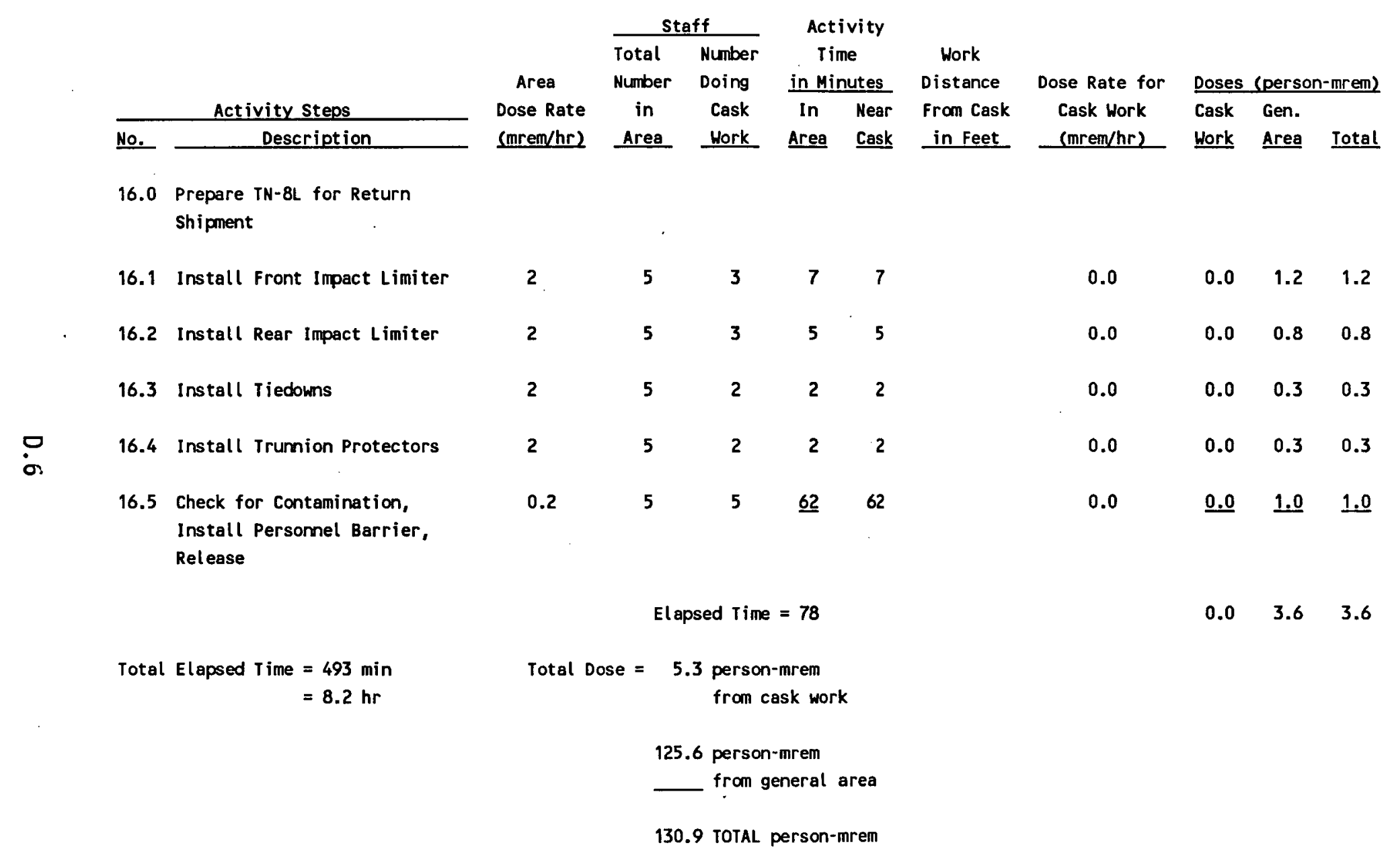




\section{DISTRIBUTION}

No. of

Copies

\section{OFFSITE}

12 DOE/Office of Scientific and Technical Information

8 Office of Civilian Radioactive Waste Management

U.S. Department of Energy 1000 Independence Avenue, SW Washington, D.C. 20585

ATTN:
J. Carlson
M. Conroy
W. Lake
W. Lemeshewsky
R. Milner
V. Trebules
E: Turner
J. Williams

K. Grassmeier

Yucca Mountain Project Office U.S. Department of Energy

P.0. Box 98518

Las Vega, NV 89193-8518

M. Klimas

DOE-Chicago Field Office

U.S. Department of Energy

Transportation Program Office 9800 South Cass Avenue

Argonne, IL 60439

M. Fisher

DOE-Idaho Field office

U.S. Department of Energy

550 Second Street

Idaho Falls, ID 83401
No. of

Copies

\section{J. Strah1}

Battelle Pacific Northwest

Laboratories

370 L'Enfant Promenade,

Suite 900

Washington, D.C. 20024-2115

3 Oak Ridge National Laboratory

P.0. Box 2008

Oak Ridge, TN 37831

ATTN: D. Joy

R. Pope

R. Raw

2 Sandia National Laboratory

P.0. Box 5800

A1buquerque, NM 87185

ATTN: R. Luna

T. Sanders

2 Science Applications

International Corporation

Transportation and Operations

P.0. Box 2501

Oak Ridge, TN 37831

ATTN: R. Best

3 Roy $F$. Weston Company, Inc.

955 L'Enfant Plaza, SW

Washington, D.C. 20024

ATTN: P. Bolton

J. Richardson

R. Hahn 
No. of

Copies

2 E. J. Bentz \& Associates, Inc. 6090B Franconia Rd

Alexandria, VA 22310

ATTN: $E$. Bentz

R. Peterson

K. Henry

EG\&G Idaho, Inc.

P.0. Box 1625

Idaho Falls, ID 83415

4 TRW Environmental Safety

Systems Inc.

2650 Park Tower Drive

Suite 800

Vienna, VA 22180

ATTN: B. Teer

D. Dawson

D. Johnson

J. Mayer

P. Standish, TMSSC

Westinghouse Electric Company

101 Convention Center Drive

Las Vegas, NV 89109

B. Wakeman

Virginia Power

Innsbrook Technical Center

5000 Dominion Blvd.

Glen Allen, VA 23060
No of

Copies

ONSITE

3 DOE-Richland Field Office

D. Trader

D. Langstaff

J. Sutey

Westinghouse Hanford Company

J. Lavender

17 Pacific Northwest Laboratory

P. Daling

C. Hostick

G. McNair

D. Payson

K. Schneider

S. Short

R. Smith (5)

Publishing Coordination

Technical Report Files (5) 